\title{
MOX
}

\section{A User's Guide}

J. A. Buchanan

E. S. Gilbert

March 1984

Prepared for the U.S. Department of Energy under Contract DE-AC06-76RLO 1830

Pacific Northwest Laboratory Operated for the U.S. Department of Energy by Battelle Memorial Institute 


\title{
DISCLAIMER
}

This report was prepared as an account of work sponsored by an agency of the United States Government. Neither the United States Government nor any agency thereof, nor any of their employees, makes any warranty, express or implied, or assumes any legal liability or responsibility for the accuracy, completeness, or usefulness of any information, apparatus, product, or process disclosed, or represents that its use would not infringe privately owned rights. Reference herein to any specific commercial product, process, or service by trade name, trademark, manufacturer, or otherwise, does not necessarily constitute or imply its endorsement, recommendation, or favoring by the United States Government or any agency thereof. The views and opinions of authors expressed herein do not necessarily state or reflect those of the United States Government or any agency thereof.

\author{
PACIFIC NORTHWEST LABORATORY \\ operated by \\ BATTELLE \\ for the \\ UNITED STATES DEPARTMENT OF ENERGY \\ under Contract DE-ACO6-76RLO 1830
}

\begin{tabular}{|c|c|}
\hline \multicolumn{2}{|c|}{$\begin{array}{l}\text { Printed in the United States of An } \\
\text { Avathable from } \\
\text { National Technical Information Si } \\
\text { United States Department of Com } \\
5285 \text { Port Roval Road } \\
\text { Springtield, Virginid } 22761\end{array}$} \\
\hline \multicolumn{2}{|c|}{$\begin{array}{l}\text { NTI5 Price Codes } \\
\text { Microtiche A0I }\end{array}$} \\
\hline \multicolumn{2}{|c|}{ Printed Copy } \\
\hline Pages & $\begin{array}{l}\text { Peice } \\
\text { Codies }\end{array}$ \\
\hline $001-025$ & A02 \\
\hline 026.058 & $A 03$ \\
\hline $051-075$ & AO4 \\
\hline $076-100$ & A05 \\
\hline $107-125$ & A 06 \\
\hline $126-150$ & Aका \\
\hline 151.175 & Aos \\
\hline 176,200 & 109 \\
\hline $201-225$ & A010 \\
\hline $226-250$ & A011 \\
\hline $257-275$ & A012 \\
\hline 276.300 & $A_{013}$ \\
\hline
\end{tabular}


$\operatorname{MOX}$

\section{A USER'S GUIDE}

J. A. Buchanan

E. S. Gilbert

March 1984

Prepared for the U.S. Department of Energy under Contract DE-AC06-76RLO 1830

Pacific Northwest Laboratory Richland, Washington 99352 


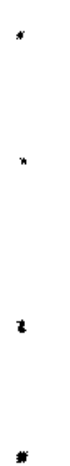


This document bas been developed on-line using a vax compter. The form used allows Mox users to interactively scan the docment file on any termal and easily create copies by queueing the file to any output device. Having the document in thita form also simplifies the process of updating and distributing documentation to report on future enhancements to MoX. 
. 


\title{
CONTENS
}

\begin{abstract}
INTRODUCTION TO MOX $, \ldots, \ldots, \ldots, \ldots, \ldots, \ldots, \ldots$
DESCRIPTION OF MOX METHODOLOGY AND OUTPUT . . . . . . . 9

PREPARING TO USE MOX

$\operatorname{PART} 1 \ldots \ldots \ldots \ldots \ldots \ldots$

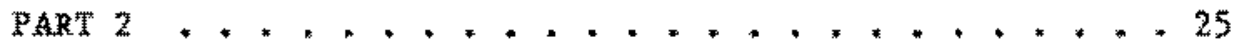

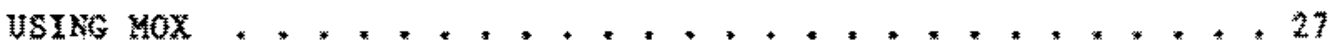

APPLIGATION TO WORXERS AT A NUCLEAR FACILITT $\ldots \ldots \ldots$

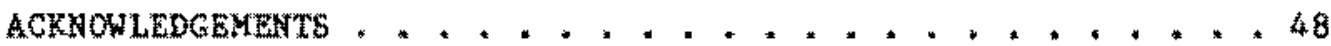

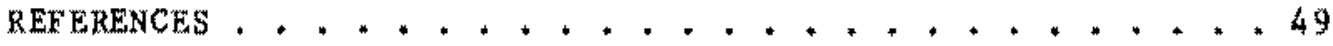

AEPENDI GTS

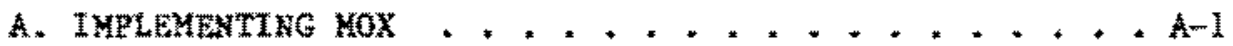

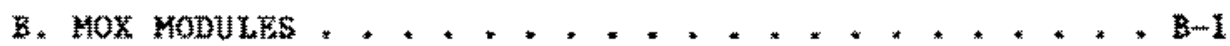

C. MOK INCLUDE STATEMBKTS $, \ldots, \ldots, \ldots, \ldots, \ldots+, \mathrm{C}-1$

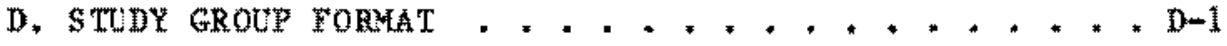

E. MODIFIED SELECT MODULE .............. E-1 2

F. MOX SPECIFICATION SESSION . . . , . , . . . F-1 2

G. MOX COMLAND FILE . . . . . . . . . . . . . . . . . . . . 20

H. MOX OUTPUT FLLE . . . . . . . . . . . . H-1 54

I. CADSES DF DEATH * . . . . . . * *...... I-1 2 
. 
What is MoX?

MOX is a computer program. It is designed to be used as a tool in assessing the relationship of occupational exposure and mortality from several opecific causes in a large cohort or follow-up study. MoX stands for Mortality and Occupational exposure analyais.

What computers will MoX work on?

MOX is tailored for use only on Digital Equipment Corporation's family of VAX (Virtual Address eXtension) computers. MoX is written in VAX-11 version 3.0 FORTRAN.

What type of methodology does Mox use?

MOX assesses the relationship of occupational exposure and mortality from several causes without reference to an outside population. The statistical tests employed take full advantage of whatever quantitative exposure data is available and provide appropriate treatment of data on exposure accumulated over time. The statistical tests also allow control for potentially confounding variables such as age, calendar year, length of employment, etc. The statistical methodology used can be considered an sdaptation of the Mantel-Haenszel method [1], or an application of Cox's proportional hazards model [2]. Although the program is designed for population-based cohort analysis, it is also possible to use MoX to conduct "proportional mortality analyses", if only data on deaths are available. 
What type of methodology do other computer prograns

for andyzing oceupational motality use?

Othet comonly aged computer program $[3,4]$ for analyzing occupational mortality data calculate standard mortality ratios (SMks) for several causes ot death. The SMR is defined as $100 \times$ (observed deaths expected deaths) where expected deathe are calculated by applying ege-sex-race-calendar yesr specific death rates for the $v_{\text {. S }}$ population* to the person-year distribution of the study population (see Honson [3] for further details on this wethod). Confidence intervals and statistical tels wor whet or not these sMR differ signtelicanty trom 100 are also provided. SMR may also be calculated separately for various exposure categories, length of employment eategories, etc.

* SKR may also be calculated rom other external populations but the use of 1.s. rates is the most common spplication of this method. 
Hov does the "Mox" approach compare with the "SMR" approach?

MOX is similar in that it also caleulates observed and expected deaths for several cauges for various categories defined by exposure or other variables, and asesses statistical significance of the differences. However, the expected deathg (or expectedg) in MoX are not calculated from U.S. rates, but rather frow tates baed on the combined categories of the atudy population. Whe "SMR analysis" the expected are the number of deaths

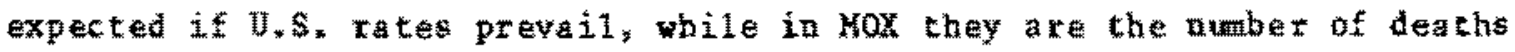
expected dedth rates for the study population do not vary by expotire category. Wox expected can also be controlled for age, sex, race and calendar year (as with the SMR approach) and, in addition, can be controlled for length of enployment, length of follon-up and othex user-defingd variables. (This is not posgible with the SMR approak because U.S. rater cannot be broken down by such variables.)

Finally, unlike other available computer programs, Mox provides statiotical tests for whether or not death rotes increase wh an increase in exposure (ot other vatables). Such testr car be bated en individual exposures or on scores absigned to exposure cateqoriec. In the latter cafe, the test i Matel's test for trend [5] (see page la for further detail). 
What are the advantages of making intemal comparizons rather than introducing zates from external population

Although colparing motality in the study population wh that of an external control (such as the U.S. population) is an important first step in andlyzing occupational mortality data, such comparisong are often difficult to interpret becauge of the bias introducte by auch factors as premeloyment selection, health indurance, and medical survelllance programa. This biss is often referred to as the "heal thy worker effect" 16$]$. Also, in tany tudies, incomplete ascertainment of deaths in the study population may mak exteral comparisons difficult to interpret.

If the SMR approach is used primerily to compate vartous subroups (with different exposure levels), shouldn't the problems related to the use of an external population disappear?

This is not necessarily true because the healthy worker effect of ten varies by age and othet tactors. If the exposure groups are not completely comparable with respect to these factors, bial may be introduced loeg Gafey [7] and Cook [8], for example). In adition, a noted above, it is not reatonable to cotrol gMRs for factors For which separate U.S. rates are not available, except by conducting separate analyses for various subgroups. When thas is done, numbers are Exequenty too small to be meaningel. Fimally, staply assegaing whether or not SMRs for yarioulexposure groupt daffer Erom 100 (seg page 2) is not a poreful, or as relevant a test, as teating for an incresse in death rates with increasing exposture, $a$ is done in Mox, 
How should one dectide when to use the Mox approach and when to ute the SMR spproach?

In wot population both approaches are weenul, but the relative contributions of the two methods will depend on the type of exposure data available, and on the distribution of exposures in the study population. Because the Hox approach is bssed on antemal comparisons, Mox will be most useful for analyzing populations with good expoture data, conaiderable variability in expoaure, and or a relatively large subgroup with little or no exposure. In other situations, Mox can stili be useful provided there is some basis for determining exposure differences within the population, but one would probably want to applement such analyseb by calculating SMks baed on external rates.

Finally, if the entire study population is expozed in a falrly uniform manner, or if the available data is inadequate to differentiate exposure groups, comparisons with an oxternal control via SMRs will probably provide the wost meaningful analys. However, even in this situation, supplemental analyses based on HOX, wh length of employment of other variables ubed as surrogates for exposure, way provide added insight

What sort of exposure data will Mox handle?

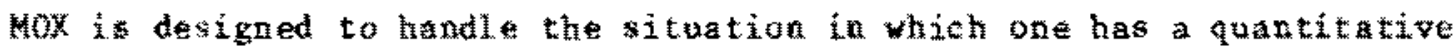
axposure measurement for each worker for each yar of employment. Hower. Wox can hadle exposure data in nearly any form with proper recoding (see page 29). 
If one were to contider only the Einal actumulated exposure total for cach worker, the and Ises would be biased towark positive correlation of aurvival and exposure simply because those workers that survive the longest have the most opportunity to accumulate exposure. (This bias is discussed by Enterline (9]). This meana tbat each worker" entire exposure history aust be considered. In addition, exposure is very likely to be correlated with such time dependent variables as age, calendar yeat, length of employment, etc=, which may in themselvea be related to mortalicy (creating a potential source of confounding). Finally, the relationship of the timing of the posures and any efacts which occur is more difficult to investigate with a chroic expotsute

How does Hox handle the special problems introduced by chronic exposure?

The basic unit of analysis for Mox fas vell as for other couptuter programs designed for use in cohort studien) is the person-yeat, It can be cefined as one year in the follow-up of one peson. Asaociated with each perton-year is the accinulated exposure at that time, as well as values for variables such as age, calendar year, length of employment which change as a worker followed through time), plus values for variabies such a race and sex which do not change wth time. Expected deathe and other tet statistics axall based on person-years which have been allocated by expoaure; in addition to other control variables. 
How does Mox deal with a posible latent period?

It is posalble to introduce a "lag" $G$ between the exposure and the effect by defining the expooure asociated with given person-year as the accumulated exposure $G$ years prior to that time.

What control variables can be included in andyoes conducted with Mox?

The vere can choose to control analyses for everd variablet including age, calendar year, tollog-up time, length of employment, job category and as many a the non time dependent user defined variables cownon choices vould be sex, foce and initial year of employment). For each of the variables selected, the usex determines the definitions of the categorites to be used.

Two of these variables are selected as the primary and secondary control variables, and provide the basis for the vertical and horizontal categories, Iespectively, in the various tables that are printed. These two variables must be chosen from anong the three variables age, calendar year and follow-up time, and ate the variables that generaly reguire the mot categories.

What type of tatictical gumaties does Mox provide?

Mox provides baberved and expected deaths by expoture category, estimated relstive risks and the resulta of various statictical testo for several specific causes of death (see page 15$).$ 
It is assumed that death are coded to the fighth Revision of the International Classification of Diaeaser (ICD). A complete list of the cauges for which MOX provides various statiotical tests is given in Appendix I.

What alse does Mox provide?

In addition to the tumanes noted above, Mok providea tables of person-years and (as an option) deaths for any selected causes. The tables are distributed by the variables chosea as the primary and secondary control vartables, and by exposure categories. Tables of exposure meang and variances are alo provided in a like maner. Finally, all of the above can be obtained broken down by the other control variables included in the analysis (i.e., length of employment, sex, etc.).

Does Mox provide estimate of the effect of exposure?

Hox provides ony statiotical teats for the asociation of exposure and mortality, plus the relative riskg for each expouse category. However, the sumary tables noted above could be edited and used as input for satistical programs such as RUMMAg [10] or GLIM [11]. 
A. Notation

The following notation is needed to adequately describe Mox methodology and output: (This is not the notation used in the program itself.)

$n=1, \ldots, N$ indexes workers in the study

$i=1, \ldots, I$ indexes control strata

$j=1, \ldots, \mathrm{J}$ indexes exposure categories

$k=1, \ldots, k$ indexes years in the study for worker $n$ $\mathrm{n}$

$z(k)=$ the accumulated exposure, for worker $n$, $G$ years prior to the beginning $n$ of year $k$ (where $G$ is a lag period specified by the user)

$w(k)=$ the index of the exposure category associated with $z(k)$ $\mathrm{n}$

$x(k)=$ the index of the stratum of worker $n$ at the beginning of year $k$ $\mathrm{n}$

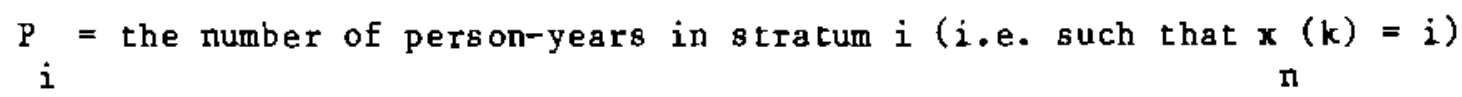


D (k) 1 if worket $n$ dies ot the cause of interese in year $k$, 0 otherwise 部

d the number of deathe from the cause of interest in stratum i

d the nuber of deatha from the caube of interegt in otratum $i$, exposure ij category j

B. Study Populetion and Exposure Distribution Description

Nox first goes through the entire data file to determine percon-year and exposure distributions for the study population. For each worker n, Mox goef through each year of follow up $k$ and determines the $x(k$ ) (i.e. clasgifies n

a11. years wh respect to strata defined by the categories of the control variables chosen), It also clasifies the exposure asociated with each person-year, $z(k)$, into one of the J apecified categories and uses this $z(k)$ n 2 in calculating the exposure mean (MU), variance (SIG), and other rexuired i i दuantities for the appropriate stratur.

Ail person-years axteonsidered to start on Janury 1 of a particular calendar year, with age and other time-related yarisbles expreased by their truncated integer values in years at that time. Most commonly, analyses will ineludw person-years from acoe specified minimal period afer employment until the person is either dead or lost to follow-up. Altemative choites, however, can be specified by the wer. After printing all user specifictations and related procesting information, a set of tables is produced by Mox foe appendix H). These tables include the following information: 


\section{I. "PERSON-YEARS AT RISK"}

These tables give the number of person-years ( $P$ ) in the study classified i

by the control variables. For the example in appendix $H$, the primary variable is taken to be age grouped in single year intervals, while the secondary variable is taken to be calendar year grouped in 5-year intervals.

II. "DEATHS FROM ALL CAUSES"

"DEATHS FROM ALL CANCERS"

These tables give the deaths from all causes and all cancers (d).

Distributions of deaths from other causes can be obtained by specifying any ICD code ranges.

III. "EXPOSURE MEANS", "EXPOSURE VARIANCES"

These tables present the means (MU) and variances (SIG ) respectively of i i

the exposures associated with the person-years in the strata defined by the control variables.

IV. "PERSON-YEARS IN EXPOSURE CATEGORY $j "(j=1, \ldots, \mathrm{J})$

These tables present the number of person-years in each of the specified exposure categories by stratum ( $P$ ).

V. "DEATHS FROM ALL CAUSES IN EXPOSURE CATEGORY j"

"DEATHS FROM ALL CANCERS IN EXPOSURE CATEGORY j"

These tables present the $d$, and can be obtained for other causes of $i j$

deaths by specifying any ICD code ranges. 
VI. "TOTAL EXPOSURE**X"; $X=1,2,3,4$

These tebles give the suas of $[2(k)]^{*}$ tor each atratum defined by

the primary and secondaxy control variables. For most applications of Mox there will be no reas on to print these tables, however, display of these sums is available as an option.

The above tables may be obtained eparetely for each stratur i determined by all of the stratification variables, and may also be obtained collapsed over all but the primary and secondary variables. In the example in appendix H. age and calendar year were the only stratification variables. If, for instance, Length of employment had aloo been celected as a atratification variable wh two categories (les than 10 year and 10 or more yeart) separate tables for each of these two strata coutd have been obtained.

c. Description of the wethode used by Mox to relate exposure and mortality from several cause

In this section a detailed description of the methodolosy exployed in Mox is given. The output produced by hox relating exposure and mortality from several causes is described in Section $D$. The analysis based on grouped exposure data is described first, since this may be more easily understood by those accustcmed to SMR type analyses. To analyze data using the Mox approach, expected deaths in each exposure category and statum are calculated by wutiplying the number of person-years in that category and stratumby the death rate for the combined exposure categories in that stratua. The total number of deaths expected in a given exposure category is obtained by suming cyer atrata. That is, the cotal number of death expected in aategory is given by

$$
E=\underset{j}{\operatorname{Sum}} E \stackrel{i j}{i} i
$$


The total number of observed deaths in category $j$ is given by

$$
0_{j}=\operatorname{Sum}_{i} \mathrm{ij} \text { Note that } \operatorname{Sum}_{j} E=\operatorname{Sum}_{j} 0=d
$$

As a summary measure for each exposure category, the Mantel-Haenszel [1] relative risk, as adapted for a cohort study, is calculated. This relative risk is given by

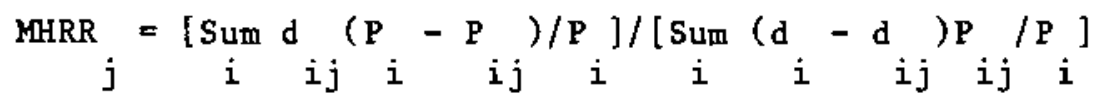

and can be thought of as the risk of category $j$ relative to the pooled remaining categories.

A test of whether the number of deaths observed in category $j$ differs significantly from that expected can be obtained by calculating the Mantel-Haenszel test statistic with the remaining J-1 categories pooled, and the finite population correction factor omitted. That is, the approximately normally distributed tegt statistics are given by

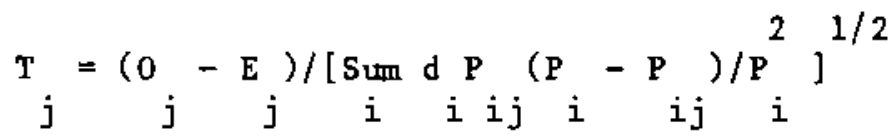

Upper and lower $95 \%$ confidence limits for the relative risks may be obtained using the test based procedure of

Miettinen [13] as MHRR $\stackrel{+}{1-1.96 / T}$ j

More generally, 1 - alpha level confidence intervals could be calculated by substituting the alpha/2 percentage point of a standard nomal distribution for the value 1.96 . 
Mantel-Haenszel also describe the calculation of a test statistic for assessing overall differences in the relative risks for the $J$ exposure categories. This statistic, which under the aull hypothesis of no differences in mortality among the exposure categories, has a chi-square distribution with $\mathrm{J}-1$ degrees of freedom. It is defined as follows:

$$
x^{2}=\underset{j}{\operatorname{Sum}} \operatorname{Sum}(0-E)(0-E) v_{j}^{-1}
$$

where $v_{j k}^{-1}$ is an element of the inverse of the matrix defined by

$$
\begin{aligned}
& v_{j k}=\operatorname{sum}_{i} \mathrm{P}_{i j}\left(1-\mathrm{P}_{i j}\right) \text { for } j=k \text { and } \\
& v_{j k}=-\operatorname{sum}_{i} \mathrm{P}_{i \mathrm{ij} i k} \text { for } j \text { not }=k
\end{aligned}
$$

Mantel's test for trend [5] as adapted for a cohort study by Hakulinen [14] can be obtained by calculating the approximately normally distributed test statistic given by

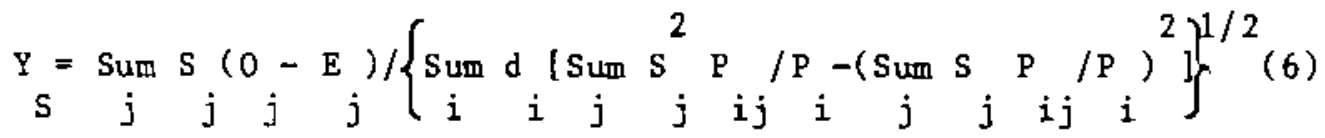

where the $S$ designate exposure values or scores assigned to the $J$ categories. $\mathrm{j}$

Unless otherwise specified, MOX uses the average of the exposure values vithin an exposure category as the score for the category. It is evident that the numerator of this etatistic will be large when large excesses ( 0 - E) are associated with large $S$.

The numerator of this statistic can also be written as

Sum Sum S d - Sum d Sum S P /P .

$i \quad j \quad j i j \quad i \quad i j i j i$ 
In this form, it is evident that the statistic could be calculated even if categories were so fine that only one exposure value was included in each category, which would be equivalent to analyzing ungrouped exposure data. In this case, many of the $d$ and $P$ would be zero.

$i j \quad i j$

For ungrouped exposure data, an altemative way of writing the statiatic $\mathrm{Y}$ is

$$
\begin{aligned}
& 21 / 2 \\
& Y=[S u m \operatorname{Sum} D(k) z(k)-\operatorname{Sum} d \mathrm{MU}] /[\text { Sum } d \mathrm{SIG}] \\
& \begin{array}{llllllllll}
z & n & k & n & n & i & i & i & i & i
\end{array}
\end{aligned}
$$

In this form, the numerator may be viewed as the difference between the sum of the exposures of workers who die of the cause of interest and the sum of the mean exposures of similar workers (same stratun) at risk of dying.

\section{Description of output giving results of analyses relating exposure and mortality}

RESULTS OF ANALYSES BASED ON UNGROUPED EXPOSURE DATA (see page 30 of Appendix H for example)

NUMBER OF DEATHS: $d=\underset{i}{\mathrm{~s}} \mathrm{~d}$

OBSERVED MEAN: The mean of the exposures at death of the workers dying of the cauge of interest, Sum Sum $D(k) z(k) / d$.

$$
\mathrm{n} \mathrm{k} n
$$

EXPECTED MEAN: The expected mean of the exposures at death as suming mortality does not depend upon exposure, $\underset{i}{\operatorname{sum}} d_{i} \mathrm{MU} / \mathrm{d}$.

TOTAL VARIANCE: Sum d ${ }_{i}{ }_{i}{ }^{2}$, used in the denorinator of the test statistic. 
TREND TEST STATISTIC:

The statistic wed to test for an asachation of exposure and mortality from the cause of intereat, See $Y$, equation (7) on pase 15.

UXADJUSTED ONE-TAIL PALUE: This is the pualue for the test for trend

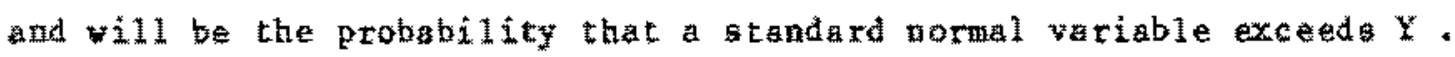

ADIUSTED ONE-TAILED P-VALUE: This will be the unadjused p-value given above plus a term based on the third and fourth moments of the exposure distributions. The adjugtment is obtained from an Edgeworth aeries expansion as described in [12], and should provide a more accurate assessment of the p-value when exposure diatributions deviste stbutantially from normality. This aduotment is probably not adequate wen extreme outliers axe present; in $f a c t$, adjusted p-values which exceed unity matocesionally result.

RESULTS OF ANALYSES BASED ON GROURED EXPOSURE DATA Isee page 38 of Appendix $H$ for example)

OBSERVED ERRQUENCIES:

$0_{j}=$ the number of deaths observed in exposure category $j$.

ExpCTED FREQUENCIES: $\quad \mathrm{E}_{\mathrm{j}}$, the number of desths expected in exposure categony j ilt death rates do not vary by expouture. See equation (1) on page 12 . 
RELATIVE RISKS: These are the Mantel-Haengzel relative risks of category $j$ relative to the pooled remaining categories. These risks are the MHRR given by equation (2) on page 13 .

TEST STATISTICS: These are the Mantel-kanszel test atatiatics for assessing whether the relative risks for categories $j$ differ significantly from unity. See $T_{j}$ defined by equation (3) on page 13 .

UPPER AND LOWER BOUNDS

FOR THE RELATIVE RISKS: These are the $95 \%$ confidence limits obtained by applying the test based procedure of Miettinen [13] and are given by equation (4) on page 13.

NUMBER OF DEATHS: $\quad d$

OBSERVED MEAN SCORE: Similar to the observed mean based on ungrouped exposure data but with scores $S$ replacing the exposure values, given by Sur $s 0 / d$. j j j

EXPECTED MEAN SCORE: Similar to the expected mean based on ungrouped exposure data but with scores $S$ replacing the exposure values, given by $\operatorname{Sum} S E / d$. $j \mathrm{j} j$

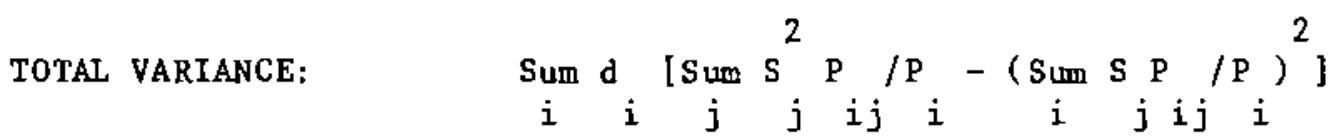
from the denominator of equation (6) on page 14.

TREND TEST STATISTIC: The statistic used to test for an association of exposure and mortality from the cause of interest. See Y, equation (6) on page 14 . 
UNADJUSTED ONE-TAILED P-VALUE: This is the p-value for the test for trend and will be the probability that a standard normal variable exceeds $Y$.

ADJUSTED ONE-TAILED P-VALUE: This will be the unadjusted p-value given above plus a term based on the third and fourth moments of the grouped exposure distributions. The adjustment is obtained from an Edgeworth series expansion as described in [12], and should provide a more accurate assessment of the p-value when exposure distributions deviate substantially frow normality. This adjustment is probably not adequate when extreme outliers are present; in fact, adjusted p-values which exceed unity may occasionally result.

CHI-SQUARE TEST FOR HOMOGENEITY

( $\mathrm{J}-1$ DEGREES OF FREEDOM): This test statistic is designed to detect overall deviations of observed and expected deaths. See the definition of $x^{2}$ given in equation (5) on page 14. 
(NOTE: Part 1 of this section is a discussion of basic techniques used in computer-based population studies. You may wish to skim the material or simply skip to Part 2, page 25)

PART 1. THE CASE AS THE UNIT OF ANALYSIS

A case consista of all the information gathered about a particular individual. Each unit of information is called a variable, and each case within a study group contains one value for each of these variables. For instance, the study group sample illustrated in Figure 1 (page 20) contains a unique research number; birth, hire, termination and death dates; sex, race, job and cause of death codes; and the amount of exposure received annually in the years 1950 thru 1955 . The case of every other individual in this study group would also consist of these same variables in the same order. 


$\begin{array}{lllllll}\text { (1) } & 135791357 & 1 & 1927 & 1950 & 1953 & -999 \\ (2) & 246802468 & 1 & 1925 & 1950 & -999 & -999 \\ (3) & 357913579 & 1 & 1920 & 1951 & 1954 & 1954 \\ (4) & 468024680 & 1 & 1917 & 1951 & 1952 & 1953 \\ (5) & 579135791 & 1 & 1915 & 1952 & -999 & -999 \\ (6) & 680246802 & 1 & 1912 & 1952 & -999 & -999 \\ (7) & 791357913 & 1 & 1910 & 1953 & 1955 & 1955 \\ (8) & 802468024 & 1 & 1905 & 1953 & 1954 & 1955 \\ (9) & 913579135 & 1 & 1900 & 1954 & -999 & -999 \\ (10) & 024680246 & 1 & 1895 & 1954 & -999 & -999\end{array}$

Research \# Record \# Sex Code Race Code Job Code Cause of Death Code

$\begin{array}{lllllll}(1) & 135791357 & 2 & 1 & 1 & 2 & -99 \\ (2) & 246802468 & 2 & 1 & 1 & 2 & -99 \\ (3) & 357913579 & 2 & 2 & 1 & 4 & 162 \\ (4) & 468024680 & 2 & 1 & 2 & 3 & 151 \\ (5) & 579135791 & 2 & 1 & 1 & 1 & -99 \\ (6) & 680246802 & 2 & 1 & 1 & 1 & -99 \\ (7) & 791357913 & 2 & 1 & 2 & 2 & 410 \\ (8) & 802468024 & 2 & 2 & 1 & 4 & 530 \\ (9) & 913579135 & 2 & 1 & 1 & 1 & -99 \\ (10) & 024680246 & 2 & 1 & 1 & 3 & -99\end{array}$

Research \# Record \#

$\begin{array}{lll}\text { (1) } & 135791357 & 3 \\ \text { (2) } & 246802468 & 3 \\ (3) & 357913579 & 3 \\ \text { (4) } & 468024680 & 3 \\ \text { (5) } & 579135791 & 3 \\ \text { (6) } & 680246802 & 3 \\ \text { (7) } & 791357913 & 3 \\ (8) & 802468024 & 3 \\ (9) & 913579135 & 3 \\ \text { (10) } & 024680246 & 3\end{array}$

Research \# Record \#

$\begin{array}{lll}(1) & 135791357 & 4 \\ (2) & 246802468 & 4 \\ (3) & 357913579 & 4 \\ (4) & 468024680 & 4 \\ (5) & 579135791 & 4 \\ (6) & 680246802 & 4 \\ (7) & 791357913 & 4 \\ (8) & 802468024 & 4 \\ (9) & 913579135 & 4 \\ (10) & 024680246 & 4\end{array}$

1950 Exposure 1951 Exposure 1952 Exposure

\begin{tabular}{|c|c|c|}
\hline & & \\
\hline 01500 & 00700 & 01800 \\
\hline 02100 & 01300 & 02300 \\
\hline-9999 & 00250 & 00200 \\
\hline-9999 & 00400 & 01600 \\
\hline-9999 & -9999 & 00100 \\
\hline-9999 & -9999 & 00150 \\
\hline & -9999 & -9999 \\
\hline & -9999 & -9999 \\
\hline-9999 & -9999 & -9999 \\
\hline-9999 & -9999 & -9999 \\
\hline
\end{tabular}

1953 Exposure 1954 Exposure 1955 Exposure

$\begin{array}{lll}01200 & -9999 & -9999 \\ 01700 & 01400 & 01800 \\ 00300 & 00500 & -9999 \\ -9999 & -9999 & -9999 \\ 00150 & 00100 & 00100 \\ 00000 & 00200 & 00150 \\ 02300 & 03100 & 01700 \\ 00300 & 00250 & -9999 \\ -9999 & 00100 & 00150 \\ -9999 & 01100 & 01600\end{array}$


The information gathered in any type of study is usually coded to simplify the process of recording it on machine-readable media. A coding scheme equates numeric or alphabetic characters to each value of $s$ ome or al1 of the variables. This speed data entry by reducing the number of key strokes and allows the information to be represented in far less space than would otherwise be possible. For example, in our study group sample we have coded each worker as being in one of four general job categories. Let us suppose the job categories are white collar, nuclear, craftsmen and service. By equating white collar with a numeric 1; nuclear with a numeric 2; and so on, we have represented each category with a single digit. As a rule, variables are recorded so that each case occupies one or more 80-character records. This, of course, is mandatory if you are using punched cards; but regardless of the recording medium being used, it is a good practice to limit the size of each record. The size selected should allow your system editor to easily manipulate the records; and, if possible, should permit each record to be displayed on a single line by both your teminal and printer.

VARIABLE TYPES

A variable may be coded either numerically or alphanumerically. The distinction between the two types is important because each is processed differently by the computer. A numeric variable may be represented by $a$ single digit, such as a code for sex; or by multiple digits, such as a research number, as shown in our sample. This type of variable can be used in mathematical operations. On the other hand, an alphanumeric variable is represented by any combination of characters and cannot be used in mathematical operations. Thus, although it is always possible to recode an alphanumeric value into a numeric form; it makes good sense to use only numerically coded variables in the first place. This grants the flexibility of operating on each variable in whatever ways prove necessary. 
Quite often, in any type of population study, values for all variables are not available. A missing value code must then be substituted to distinguish missing data from true zero values. The code selected must be such that confusion with an actual value is avoided. It is wise to choose a code of the same size and type as the field allotted for the particular variable. In our sample, a code of -999 is used for all date variables, four character numeric fields; a code of -99 for the cause of death variable, a three character numeric field; and a code of -9999 for all exposure variables, five character numeric fields. Note that a legitimate value for any of these variables would be greater than or equal to zero.

\section{CASE IDENTIF ICATION AND SEQUENCING}

A field for case identification is often reserved in each record of each case. This variable should contain a unique research number derived from characteriatics peculiar to the individual; for example, a social security or payroll number. In addition, it is useful to reserve a field in each record for record sequencing, as in our sample. This gives you the capability of sorting your file by case identification and record number if necessary, perhaps after updating. 
THE USE OF BINARY SUBFILES

The cases selected by MOX for processing may be saved on a permanent binary (unformatted) subfile. We refer to it as a subfile because it generally consigts of a subset of the cases in a study group. However, it may just as well contain a binary representation of all of the cases. Substituting this type of file for the original formatted one in subsequent processing offers distinct advantages. Binary representation of data results from formatted (externally-coded) data being converted into a machine-readable (internal) form. In analyzing lange study groups, a great deal of time is spent reading formatted data and waiting for system sofware to convert them into an internal form. Because a binary file contains the results of this time consuming process, this step may be eliminated in any future processing of the study group. Using a binary file for input may reduce processing times by as much as a factor of ten. 
Another consideration is the amount of storage space required by a 8 tudy group file. Formatted data requires one byte (character) of storage for each position of each record. Binary data requires either two or four bytes for each variable. Short integer variables may be represented by two bytes, long integer and single precision floating variables require four bytes apiece. To illustrate the difference in storage requirements let us look at the study group sample again. Each case in the formatted mode would use 92 bytes exclusive of spacing between fields. Assuming that the exposure fields each use four bytes (single precision floating), the research number fields also use four bytes (long integer) and that all other variables use two bytes apiece (short integer); then each case in binary form would require 64 bytea. Note also that in a formatted file each space between fields occupies a position whereas a binary file contains no spacing. Thus, any decrease (or possible increase) in storage demands resulting from data conversion is dependent upon the nature of your study group, the coding scheme used to record the information and whether all cases, or just selected ones, are saved. In most enviornments, the unlikely prospect of even a sizeable increase would be more than offset by the benefit of greatly reduced processing times.

Binary files, of course, cannot be altered and they do require additionsl time as vell as storage to create. Consequently, if you are contemplating editing or updating a formatted file before performing another Mox run there is nothing to be gained by creating a subfile. Once your study group is fairly stable, however, it pays to make a subfile of all of your cases. This way, regardless of the cases chosen for inclusion in an analysis, you can use this subfile instead of your formatted file. If you are frequently selecting the same cases, it would also pay to create a subfile of just the selected cases. 
PART 2. PROCESSING CONSIDERATIONS

Operating on a VAX, and processing data as soon as it is read, allows MOX to handle very large study groups. The VAX, a virtual memory machine, uses disk storage as an extengion of core memory. Therefore, the actual number of cases that can be processed depends upon the amount of temporary disk storage and core memory available to you. Users should be aware, however, that results from processing a very large number of cases (over 100,000) may not be accurate unless precautions are taken. Exposure related numerical quantites may become so large that they overflow their allotted space in memory, or suffer from serious roundoff error. In addition to steps taken by MoX to limit such problems, the user may prevent their occurrence by scaling large exposure values. This is a good practice to follow regardless of the size of your study group.

For example, assume that our sample in Figure l (page 20) has radiation exposure recorded in millirems. Dividing each value by 1000 will convert the readings into rems. This will allow exposure readings to be accurately sccumulated over a larger number of cases. Scaling is performed by the user by manipulating the data after it is read, but before it is processed by Mox. 
A wore efficient method of scaling may be used if the exposure variables are recorded without decimal points, i.e., as integer values. For instance, to scale the exposure data in our sample it is only necessary to modify the format used to read it. Reading each variable as an (F5.3) value rather than as an (F5.0) value is equivalent to dividing the values by 1000 .

Normally data are read from a disk file. If the data reside on a storage medium other than disk, they should be copied there before processing. This, of course, requires sufficient disk storage to contain the entire study group in one file. If this requirement creates a problem, the data may be read directly from magnetic tape. This approach is not recommended, unless necessary, due to the penalty extracted in MoX processing time. 
VARIABLE DEFINITIONS

Using MOX requires an understanding of the use of several input variables which are defined either in a specification session (see Step 4, page 37) or in the SELECT routine (see Step 2, page 31). Generally those variables that are fixed for a particular run, i.e. do not vary from worker to worker, are defined in the specification session, while those that must be defined for each worker are determined in the SELECT routine.

The following fixed variables are defined in the specification session:

ISTDYS, a four digit calendar year indicating the first year for which exposure data is to be considered.

ISTDYE, a four digit calendar year indicating the final year to be included in the study.

PRIMDESC, choice of primary control variable.

SECDESC, choice of secondary control variable.

STRATCYR, option for controlling by calendar year.

STRATLEN, option for controlling by length of employment.

STRATFUE, option for controlling by follow-up time.

STRATJOB, option for controlling by job category.

STRATUSE, option for controlling by non-time dependent user defined variables. LATENT, the number of years by which exposures are to be lagged.

The following variables are defined for each worker in the SELECT routine:

IBYR, a four digit calendar year of birth.

ICAUSE, an Eighth Revision ICD three digit code for cause of death (or a missing value code for workers still alive).

IDYR, a four digit calendar year of death (or a missing value code for workers still alive). 
IHYR, a four digit calendar yest indicating initial employment date.

IF" (last date included in the study for workers ctill employed).

The dateg IHYR and IFYR are used for the calculation of length of employment which may be used s a critcrion for selecting cases, and/or may be selected a a time dependent control variable.

IUSEVI thru IUSEV5,

These variablec are needed only if traticication by nontime dependent user defined control variables is desired. Common shoices for these yatiables would include 3 ex race, a code for plant or company, inital employment year, a code for smoking habits, ete.

IYEMP, a four digit calendar year designating the first year to enter into the analys for the subject being procesaed. A vorker should not enter the anglysis until the specified LATENT period has passed, and, since all person-years begin on January 1, a worker should not enter the analysis until the year following IHY + LATENT. Thus the minimum permissible value for IYEMP is IHY + LATENT + 1. Also, it the study is limited to workers who have been employed for at least M years,

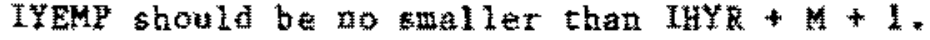

Ixt更M, four digit calendax year designating the last yeat to enter into the analysis for the case being procesced. For many applications, this will be the year of death (IDYR) or a fixed final year (ISTOYE), whichever occurs first. (When available, the yeat lost ro follow-up could be substituted for ISTDYE).

NoTE: A proportional moztality anslysis can be performed by specifying LATENT as zero, setting LYEMP equal to IDYR - I and ITTERM equal to INYR.

Jotcone, an integer job code, usually read in difectly roo the data tile. Needed only if job category is to serye a potential control variable or it to be used in the delintion of the exposure vector.

JOBCAT, an integer job category. Each value of JOBCAT will include one or more, not necessarily consecutive, values of JoBcoDE. The value of JOBCAT is determined by calling the subroutine JOBCA TG that usea the job category specifications you will enter in step 4 (see pase 42 ). Record (20) on page 32 illustrates how JobCATy is called after JOBCODE has been read in for a case. JOBCA 1 is not referenced at the call statement becauge it is contained in comMON.MOX included by record (2). (see Appendix 0 ). 
EXPOSURE, This is an array which must be filled with the exposure values associated with each year of the study from 1 (for calendar year ISTDYS) to ISTDYE - ISTDYS + 1 (for calendar year ISTDYE). In the sample SELECT routine in Figure 2 (pages 32,33 ), MOX reads in an exposure vector YEXP where YEXP(I) denotes the annual exposure received by the worker being processed in year I (indexed as noted). Values for years before and after the worker's period of employment may be designated as zero or as a negative missing value code (both are treated as zero). Note that the indexing for this vector does not depend on the particular employment years of the worker.

In the sample SELECT routine on page 32, MOX calculates the cumulative exposure associated with each calendar year as

$$
\operatorname{EXPOSURE}(I)=\operatorname{Sum}_{K=1}^{I-1} \quad Y \operatorname{EXP}(K) \quad \begin{gathered}
{[\text { See records }(9) \text { and }(10) \text { of }} \\
\text { the SELECT routine] }
\end{gathered}
$$

For some applications it may be more straightforward to read in the cumulative EXPOSURE vector directly and omit this step [records (9) and (10)] of the SELECT routine. See example 4 (page 30).

As noted on page 27, the user also defines the fixed variable LATENT (constant for all workers in a particular run) which designates a value by which exposures are to be lagged. In carrying out analyses, MOX takes LATENT into account by using EXPOSURE(I - LATENT) as the exposure value to be associated vith year $I$. This provision for the latent period is done outside the SELECT routine and is not shown.

For the examples presented in this manual, quantitative measurements of radiation exposure for each worker for each year of employment were available. These measurements could then be used directly in defining the array YEXP of annual exposures. In other studies, exposure data may not be in this form and recoding may be necessary. The following are a few examples of such recoding .

Example 1: Exposure data is available only an an estimate of the cumulative exposure $X$ over the entire employment period of $K$ years. In this case, it would be necessary to distribute this total over the relevant period based on available knowledge of the probable timing of exposures. In the absence of such knowledge, the simplest way of distributing exposure vould be to assign $\mathrm{X} / \mathrm{K}$ as the YEXP value for each year of employment. 
Example 2: Years of employment are used as a surrogate for exposure. In this case, the YEXP value for each year that an individual is employed in the industry or job is assigned a value of 1 , and each year he is not employed in the industry or job is assigned a value of zero.

Example 3: For each worker, the period of time worked in each of jobs $1,2, \ldots . \mathrm{L}$ is known. If the annual exposure associated with each of the jobs can be quantified, these exposures could then be assigned to the relevant years in defining the array YEXP.

Example 4: Each worker can be assigned to a single job category designated by JOBCAT (defined by calling JOBCATG), but it is not possible to quantify the exposure associated with each category in a meaningful way. In this case, the EXPOSURE array could be filled directly with the value of JOBCAT and the steps given in records (9) and (10) of the SELECT routine (page 32) omitted. A test for trend could be obtained if the job categories could be even roughly ordered with respect to exposure, but other tests provided by Mox might be more meaningful. Note that an analysis of initial year of employment, or other fixed variables, could be accomplished in a similar manner. 
We will now describe the steps to follow to run Mox:

Step 1. IMPLEMENTING MOX

Follow the instructions in Appendix A to implement MOX on your computer system. The modules that make up MOX are listed in Appendix B.

Step 2. MODIFYING THE SELECT SUBROUTINE

You must modify the SELECT subroutine for your own use. The purpose of this routine is to read in the relevant variables for each case, select cases that you wish MOX to analyze and use the data read in to define the basic variables needed for analysis.

An example of a SELECT subroutine is shown in figure 2 on the next page. We will examine each of these FORTRAN instructions and describe their purpose. This particular subroutine has been designed to analyze the cases in the sample study group illustrated in Figure 1 (page 20). 


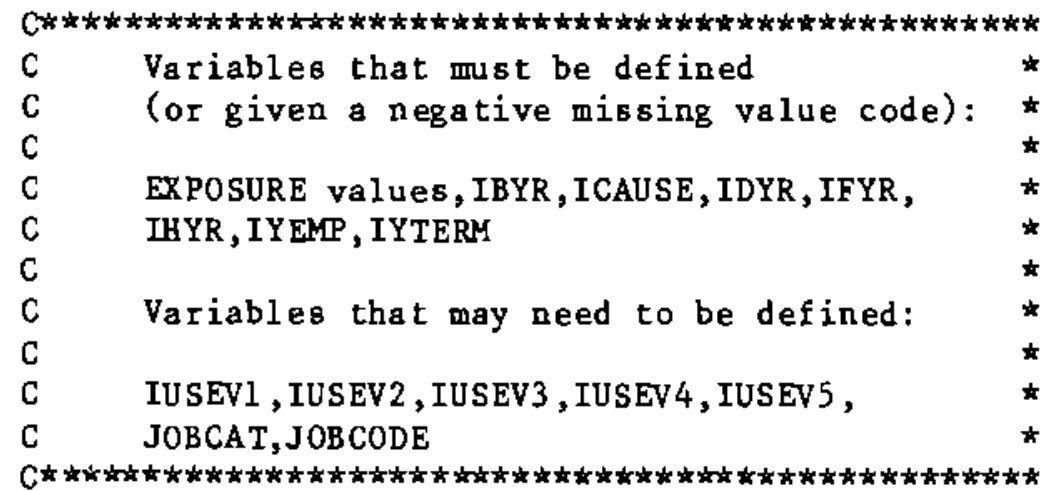

REAL*4 YEXP(6)

C----Set end of file indicator $\mathrm{EOF}=$. FALSE.

C---------Trangform yearly exposures into cumulative exposures D0 $200 \quad I=2,6$

$200 \quad \operatorname{EXPOSURE}(I)=\operatorname{MAX}(\mathrm{YEXP}(I-1), 0.0)+\operatorname{EXPOSURE}(I-1)$

C--------If creating subfile write case IF (SUBSET) WRITE (ISF)

C----No....read a binary case

300 READ (INP, END $=700$ ) IRESN, IBYR, IHYR, IFYR, IDYR, IS EX, IRACE, $+$

C-----Increment \# of records read

$400 \quad \mathrm{NRR}=\mathrm{NRR}+1$

C-- Male worker?

IF (ISEX.NE.1) GO TO 100

C--n--Yes...white?

IF (IRACE. NE.1) GO TO 100

FIGURE 2. SAMPLE SELECT SUBROUTINE 


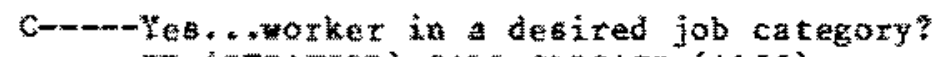

IF (ITRATIOB) CALL JOBCA To $(* 100)$

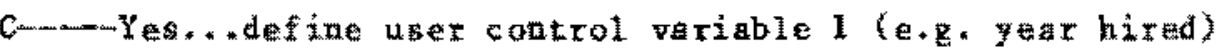

IF (STRATUSEL) IUSEVI = IHYR

C-m-Worker alive?

IF (IDYR, GE. ISTDYS.AND.IDYR. LE. ISTDYE) GO TO 500

C---m-Yes... exployed 2 or more years?

IF (IFYR-IHYR.LT.2) GO TO 100

C-m-mom Yes... detine first last years to consider TY EMP $=$ IHY R + LATENT+1

IYT TERU $=2 S T$ TVY

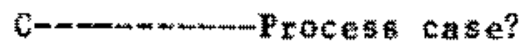

IF (IVEMT.ET.IYTERM) GO TO 100

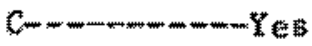

co to 600

C-...-No. . Baployed 2 or more years?

c-a--(no not count year of death if game as final year of employment)

500 LEMPEIFYR - IHYR

IF (IDYR. EQ.IFYR) LEMP=LEMP - I

IF (LMMP,LT,2) CO TO 100

C-m.m.m.m-mes... define first \& last years to consider IY EMF $\mathrm{THY}$ TH LATENT+1

IYTERM IDYR

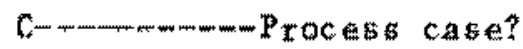

IF (IYEMP.GT. IYTERM) GO TO 100

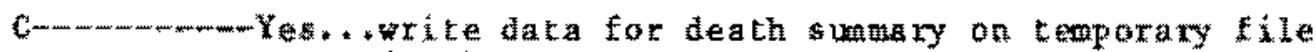
WUIT (USh) CASE

Camm-If input thle is binary a creatiog subfile whto selected cabe

C-un-Froceas cas e

600 IF (HIAARY, AND.SULSET) WRTTE (ISF)

$+$

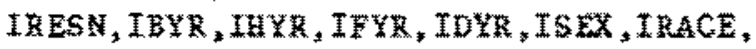
JOBCODE, ICAUSE, (EXPOSURE( 1$), 1 \times 2,7)$

RETUEN

C-m-mind a file... wet indicator

700 EOF . TRUE.

RETURN

800 Formar $(19,5 x, 11,8 x, 14,6 x, 14,2(10 x, 14) /$

$+\quad 14 \mathrm{X}, 11,9 \mathrm{X}, 11,8 \mathrm{X}, \mathrm{I1}, 13 \mathrm{X}, \mathrm{I3} /$

$+\quad 31 \times, 55.3,2(9 \times, 75.3) /$

(43)

$+\quad 31 \times, 75.3,2(9 \times, 55.3))$

END

FIGURE 2. (CONT.) 
The following explains the purpose of each instruction in Figure 2 :

Record (1)

Identifies subroutine.

Record ( 2)

Includes the statements in ComMon. MOX but does not list then. The variables in these $s$ tatements may then be used in the subroutine. Compon.mox is listed in Appendix $\mathrm{C}$.

acosi (3)

Dimensions the vector to uat for reading in tractional exposuxe values.

Record (4)

Turns the end of file indicator of

Record (5)

Fills the exposure vector used by wox with aeros. The size of this yector is Yos (YhS=50 in include etatements).

基ecord (6)

If a bindry (xather than forutted) input wode was opecified, transfers control to record (15).

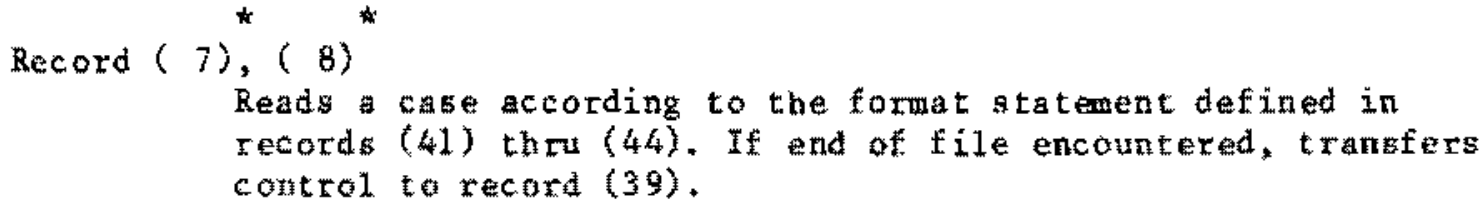

Becord (17)

Counts the number of $s$ ets of records (cases) read.

* Indicates instructions likely to require uset modification. 
Record (18)

If the worker is female, rejects the case by transferring control to record (5).

Record (19)

If the worker is non-white, rejects the case by transferring control to record (5).

Record (20)

This provides for a definition of job category which can possibly be uged as a stratification variable. The job code read in is used to determine the job category of the case. If the job code does not fall into a opecified job category, the case is rejected by transferring control to record (5).

Record (21)

Provides for a user-defined control variable. In this example the variable is defined as year hired. (User control variables 2 thru 5 could be defined in a like manner.)

Record (22)

If the worker died during the study period to be used in the analysis, transfers control to record (28).

Record (23)

If the worker was employed less than two years, rejects the case by transferring control to record (5).

Record (24), (25)

Equates the first year to consider with the year hired + LATENT + 1. (It is not appropriate to include person-years before the specified latent period has passed.) Equates the last year to consider with the end of the study period. For other studies, the year the worker was lost to follow-up might be used here.

Record (26)

If the first year to consider is later than the last year to consider, rejects the case by transferring control to record (5).

Record (27)

Transfers control to record (35).

Record (28), (29), (30)

If the deceased worker was employed less than two years, rejects the case by transferring control to record (5).

* Indicates instructions likely to require user modification. 
Record (31), (32)

Equates the first year to consider with the year hired + LATENT +1 . (It is not appropriate to include person-years before the specified latent period has passed.) Equates the last year to consider with the year of death.

Record (33)

If the first year to consider is later than the last year to consider, rejects the case by transferring control to record (5).

Record (34)

Writes the variables in cormon block CASE (see Appendix C) on a temporary binary file for use in the specified death analyses.

Record $(35)^{*},(36)^{*},(37)^{*},(38)^{*}$
If specified, the values read in fram a binary subfile are written on a new binary subfile containing just the cases selected for processing. Control is returned to MoX so the case can be processed.

Record (39), (40)

Turns the end of file indicator on and returns control to Mox. At this point, all selected cases have been processed.

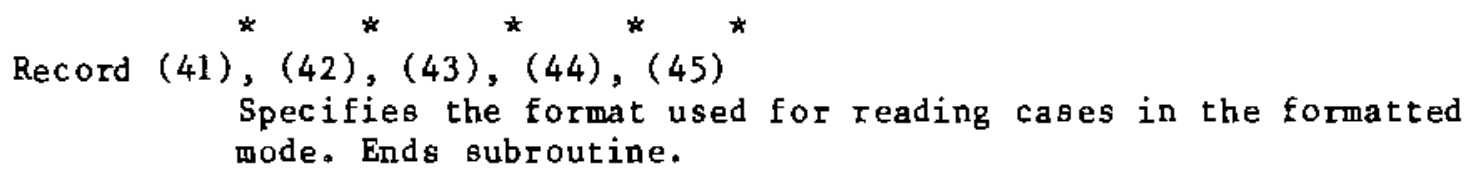

You could, of course, develop a SELECT subroutine in many ways. However, because there are variables that either must be or may need to be defined, it is easier to use the routine provided as a model and make only the changes necessary to perform your own Mox analysis. To illustrate this, we modified the sample SELECT routine in Figure 2 so it could be used to analyze a new study group in a different manner. The format of the new study group is in Appendix D. The modified SELECT routine is listed in Appendix E.

* Indicates instructions likely to require user modification. 
Step 3. LINEIHG MOX

Each time the SELEcT oubroutine is modified; you must rebuild the mox executable image to substitute the new object module. To do this, after compiling the modified subroutine (in the subdirectory created in step 1), enter:

\section{僬i inkmox}

Step 4. ENTERING YOUR SPECITICATIONS

Vsers may wish to perform a variety of MoX analyses. Changes such as transformation of exposure measurements ( $10 \mathrm{~g}$, dqare root, etc.), definition of user control variables and selection of duterent subsets of the study group population take place in the SELET subroutine, as discussed in step 2. However, the selection of control variables, the exposure categories and the latent period are all specified in an interactive specification session. This allow the user to conduct many different analyas without modifying the SElict subroutine. An interactive specification session is initioted by entering:

ruth mox

online

The first prompt is then sent to your terminat. To receive help for a prompt singly press the return key. To rectue help for proupts that ma retutite a multiple yalue tesponse, prese the control and $z$ keg Gimitaneously. Each succeding prompt is sent when suitable response is entered for the present one; otherwise help is automatically given and the prome is reis bued. Although upper case responses are acceptabla, enter your

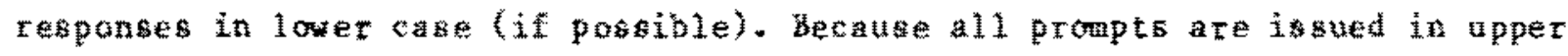
case, this helps to distinguish user input when analysis results are printed. 
After entering the specifications you will be asked for a command ile Bame. The file created by Mox wil1 coneist of prompts, helpo and respenses. Finally, you will have a choice of performing an interactive analysis based on your specifications or ending the interactive specifiction seaton. If you choose not to perform an interative malyaib, you may then oubmit the comwand file (that was just erested) to perform a batch Hox analysis. (This procedure is ciscussed in the next step on page 46. ) Appendix 5 iliustrateg a sample specification sebsion for the okudy group described in Appendix D.

The following is a list of all possible prompts and the rules for each response. Note that the cutpoint (lower catejory boundateb) referred to in this 1 ist divide a variable into specitic categorias or level the number of whith is one more than the ramer of cutpoints. For example,

if the number of cutpoints specified is 3

and the cutpoints given are $2,5,15$

the 4 categories or levels would be $\times 2,2$ up to 5,5 up to 15,15 ar more.

Note also, when you are entering values aparated by conmas, the end of a record acts as a sarator. For example,

2,5

15

would be one correct way of entering the above cutpoints; however, 2,5,

15

wonld not be a correct way. 
PROKPT: (UPPER CASE)

responge: (lower case)

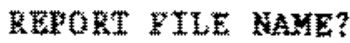

any valid file name up to 80 characters

TASKNAME?

1 to 80 characters

SWARTANG YEAR OF STUDY

any a digit integer

ENDTNG YEAR OF STUDY?

4 digit integer $<$ or atarting year of study +50

BINAE THPUT FILE?

yet or no

INPUT FLLE NABEE?

any valid file name up to 80 characters

GREATING A SUBFILE?

yes or no

(it response is yes then:)

SUBF ILE NAYE?

any valid file name up to 80

characters

PRIMADE CONTROL VARIABLE"

Segctry age, calendar year, OR

follow-up tize

* OF PRIMARY CUTPOINTS?

an integer between $2 \& 49$ inclusive

EOUAL PRIMARY CUTPOINI INTERILS?

yes bre no
VARLABLE OR ARRAY NAME:

atotion:

RPTWANE

names file to contain salys

results

TASKNAME

identifies anslysis results

wstors

opecifies first falendat year

for which exposure da ta in to

be conatidered

ISTOY E

specifies final calendar year to be included in the study

B WNARY

apectifes input form

INPNAME

names study group data file

SUBSE

if response is yes: creates a binary abtile of atudy aroup data

SUBFILE

tnames subfile to create

PaTHESC

cpecifies primary tabling

v然ritale (rows)

NTEIM

divides primary variable into

NPRIM + 1 categories (rows)

EQPCI

i. respone is yea, divides prima fy variable into equal zized categorites 
(it response is yes then:)

FIRST PRIMARY CUTPOINT, LAST PRIMARY CUTPOINT?

(1.at-first integer values)/

(4) primary cutpointe-1) must

= an integer

(if response in no then:)

PEIMARY CUTPOINTS?

abending integer values

separated by commas

SHCONDARY CONTROL YARIABLE?

SPECIFY age, calendar year, OR

follow-up time

* OF SECONDARY CUTPOINTS

an ateger between $2 \& 15$ inclusive

EQUAL SECONDARY CUTPOLNT INTERVALS?

yes or no

(it response is yes then:)

FIRAT SECONDAEX CUTPOINT,

LAST SECONDARY CUTPOHNT?

(Last-first integer values)/

(非 secondary cutpointo-1) must

$=$ an interer

(if reponse is no then:)

\$ECONDARY CUTPOLNTS?

as cending integer values

separated by commas

(prompt not issued if calendar yeat has been selected as the primary or seconiary control variabla)

STRATIFY BY CAIENDAR YEAR?

yes or no

(if response is yes then:)

H OF CALENDAR YEAR CUTPOINTS?

an integer between 1 \& 14

inclusive
IPRIM

determiaes primary categories using VPRIY these cutpoints

IPRIM

defines primery categories

SECDESC

specities secondary tabling

yatiable (columna)

NSEC

divides secondary variable into NSEC + 1 categories (column)

Euset

if respona is yes, divides secondary vartable into equal sixed categories

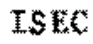

determines secondary catezories using NSEC these cutpoitts

Is

defines secondary categories

STRA TCYR

if response is yes, stratifies workers by caleadar yeat

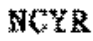

Gratifies workers into NCYR +1 levels 
PROKPT: (UPPER CASE)

response: (lover case)

CALENDAR YEAR CUTPOTNTS?

ascending integer values

separated by commas

CALENDAR YEAR DESCRIPTION FOR POR GROUP XX?

1 to 24 charactera

STREATHF BY LENGTH OF EMPLOWMENT?

yes OR no

(if response is yes then:)

* OF LENGTH OF EMPLOYMENT

CUTPOINTS?

an integer betwen $1 \leqslant 14$

inclusive

LENGTH OF ENPLOYMENT

CUTPOINT( 5$)$ ?

ascending integer values

separated by comas

LENGTH OF EMPIOYMENT

DESCAIPTION FOR GROUP XX?

1 to 24 characters

(prowpt not issued if follow-up time

hat been selected as the primary or secondary control variable)

STRATIFY BY FOLIOW-UP SINCE YEAR OF EMPLOYMENT?

$y \in$ OR no

(it reanonse is yes then:)

OF FOLLW-UP CUTPOLNTS?

an integer becween 1 : 14 inclusive

FOL WOW-UP CUTPOINTS?

ascending integer values

ceparated by comras is

TOLLAN-UP DFSCRIPTION FOR

GROUP $\mathrm{XX}$ ?

1 to 24 characters
VAWIABZE OR ARRAY NAME:

$-41-$

action:

ICYR

defolnes calendar year leyela

CYRDESC

identifies calendar year levelo

STEATEN

if response is yes, stratifies workers by length of employment

NLEN

Btratifies workers into NLEN +1 levels

T.LW

defines length of employment

levels

LENDESC

tdentifieg leng th of employment levels

STRATTUE

if response is yes,

stratifies vorkers by alow

NFu

Staticies vorkerg into NRUE + 1 levels

TFUE:

derines follow-up levels

FUEDESC

identifies follow-up level 
EROMPT: (UPPER CASE)

response: (lower case)

STHATYFY BY JOB CATEGORY?

Yes OR no

(if response i yes then:)

\$ OF JOB CA THORIES?

an integer between 1 \& 15

inclusive

* OF CODES IN JOB

CATEGORY XX?

an integer between $1: 15$

inclusive

CODES IN JOB CATEGORY XX?

integer values separated by

conmas

DESCRITTION FOR DOR CATEGORZ

$X X$ ?

1 to 2 characters

STRATIFY BY USER-DEFINED COKTROL

VARIABLE(S)

Yes OR no

\section{(if response is yes then:) \\ W OF USER-DEFINED CONTHOL \\ ATIAB LES? \\ an integer betwem 1 \& 5 \\ inclueive}

* OF CONTROL VARIABLE $X$

CUTPOINTS?

箱 integer betwen $1 \& 14$

inclusive

CONTROL VARLABLE X

CUTPOWNTS ?

ascending inteser values

separated by comma

CONTROL VARIABLE $X$

DESCREPTLON FOR GROUP $X X$ ?

1 to 24 characters
VARTABLE OR ARRAY NaME:
STRATTOB

if response is yes,

atratities workess by job

category

Noce

stratifies workers into NoCC

levels

NCODES

Bpecifies of codes for each of HoCh levels

$100 \%$

defines codeg for each of Nocc

levels

occoesc

identifies job category level.

STRATUSE

it response is yes, atratifies workers by these control vatubles

NUSE

spectites of these control variables to stratify by

NUSEX

stratifies workers into MUSEX + 1 Levelo

IUSEX

defines control variable $x$ levels

USEXDESC

identiles concrol variable $x$ levels 
PROMPT: (UPPER CASE)

respone: (Lower case)

1) OF EXSURE CUTPOLTTS?

an integer between 1 \& 14 inclusive

EXPOSURE CUTPOINT(S)?

ascending real values separated by comatas

DESCRTETION OF EXPOSULE UNTTS?

1 ch 篗 characters

LATENCY PERIOD FOR EXPOSURE?

0 or a positive integer by wich exponures are to be lagged

(prompt not issued if controlling only for primary secondary

variables)

PRINT TABLS BY PRIMARE SECONDARY CATEGORIBS ONLY?

yes OR no
VARTABLE OR ARRAY MAMT:

action:

NEXP

atratifies vorkers into $\mathrm{NEXP}+1$

exposure categories

REXP

defines exposure categories

EXPESC

identifies exposare nuits

LATENT

specifies \# of years to 1ag exposure

\section{警A A}

if responae is yes, tables are not printed for each level of specified stratification (this does not affect decth and lyses results)

\section{ThBDTH}

PHIT TABLES OF DEATHS FTOM

Al. CAt SES?

yes OR no

PLELA TAELES OF DEATHS FROM

ALL WALIGNANT NEOPLASHS?

yea of no

PRINT TABLES FOR OTHER SPECIFIED

CAUSES OF DEATH?

yes on no if responge is yes, prints deaths from ICD coded causes 0 - 999 inclusive

THETHM

it response is yes, prints deaths from ICD coded caude $140-209$ inclus

TABDTH SPC

prints deaths from specified ICD coded cauges 
PROMPT: (UPPER CASE)

response: (lower case)

(if response is yes then:)

WE OTHER DEATH TABLES?

1 or 2 or 3

OF ICD CODE RANGES TN
DEATH TABLE X?
an interer between 1 \& 15
inclusive

LOWER, UPPER RANCE OF CODES

IN DEATH TABLE T?

non-destending integers

between $0: \$ 99$

inclusive

DEATH TABULATION DESGRIPTION FOR TABLE X?

1 to 80 characters

ERTET PÓNER TOTALS?

yes of no

PRINT UNGROUPED EXPOSURE ANALYSIS RESULTS?

yes OR no

PRIKT GROUPED EXPOSURE ANALYSIS

RESULTS?

yes OR no

(if response is yen then:) ASSIGN SCORES TO THE

EXPOSURE CATEGORIES?

yes on no
VARIABLE OR ARRAY NAME:

action:

\section{NDTHGRPS}

apecifies of other death

tables to print

NICDS

specifies of ICD code ranges

for each of NDTHGRYs cables

\section{IRANGES}

defines ICD code range for each of NDTHGRS tables

DTHDEsc

identifies abs of Notugkp

atales

TABPOH

if response is yes, printe tables of exposure to the 15t, 2nd, 3rd \& 4th powere by primary \& secondary categories only

INDTy

i. respono is yes, prints analyzes of ungrouped exposures

\section{GROUPE}

if response 1 is yes, prints analyses of grouped exposures

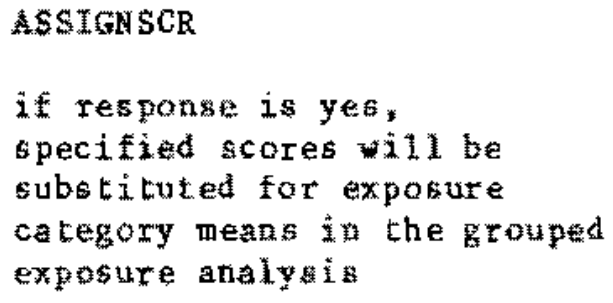


PROMPT: (UPPER CASE)

responat (lower csse)

(if response is yes then:)

EXPOSURE CATWCORY SCORES?

(3) of exposure cutpoints + 1)

real values separated by commas

COMMAND FILE MAME?

any valid file name up to 80 characters

PERFORM INTRRACTIVE ANAIXSIS BER

SPFCLETCATIONS?

yes OR no
VARIABLF OR ARRAY NAME:

$-45-$

ation?

\section{SORES}

defines exposure category ecores

COMLAME

atames command file creates it

ABORT

the pecification phase is tow complete, if response is yes on interactive analysis begins 
Step 5. USING THE COMMAND FILE

As noted in the last step, command file is created at the conclusion of

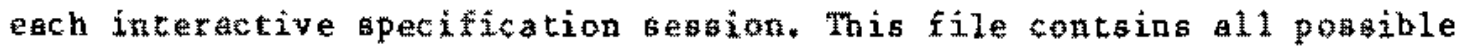
prompts and help, not just the actual prompts and any helps is saed during the session. This llows you to use a system editor to easily modify the reapones in the command file so that a variety of batch andyes can be performed, without going thru the interactive specification phase again. The comand file created Frow the specifiction session in Appendix is listed in Appendix $\mathrm{C}$. This listing is followed by a discusaion of vays in which the command lile may be modified. Appendix 11 is a listing of the output generated by subsiting the command fle in Appeadix 6 as a bateh job. 
The Mox approach is illustrated in this manun by using data from a study of mortality at the Hanford nuclear facility. The Hanford plant, located in southeastern Wathington state, has employed many workers in jobs involving some exposure to radiation. The initial purpose of this plant was the manufacture, chemical separation and purificstion ot plutonium. In addition, resarch of ditarae auture and, more recently, power generation have been conducted at the facility. Anployment records, which inclute data on age, sex,

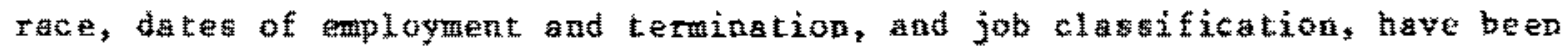
kept on 28,683 male workers and 11,190 fenale vorkers employed between 1944 and 1979.

Relatively good quantitative measurements of tadiation exposures obtained Erom personal dosimeter readings, are available for each Hanford worker for each year of exployment at Hanford. Although these data include annual measurements of exposure to several types of ionizing radiation, only wole body penetrating radiation is considered here. Such exposure is measured in rem, normalized am of several radiation types.

The sudy population for the sample analysis in appendix H consists of

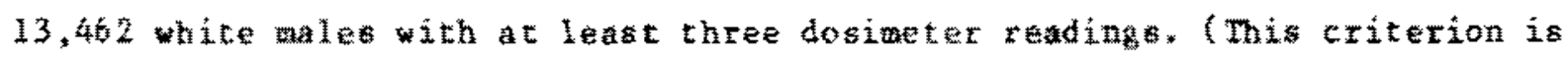
slighty different fros chst used in earlier analys ot thas population $[15,16]$. The andyes include the experience of workers until death of the study cutof date (January 1, 1979), whichever occurred irst. In many instances, the follow"up period includes many years after termination of employment at Hanford. A more complete description of the Hanford data as vel1 as interpretation of results of snalyses are given in [15] and [16]. 


\section{ACKNOWLEDGRHEN}

The authors wish to acknowledge the contribution of Kent $B$. Stewart Who developed the original Hanford Mortality Analysis program that has formed the foundation for Mox to be built upon.

We are also thankful for the motivation and insight provided by Dr, H, Denis rolley as well a cor the helpful suggestons received from Dr. Anthony R. O1sen and Sharon M. Popp. 
[1] Mantel, N. and W. Haenszel, Statistical Aspects of the Analysis of Data from Retrospective Studies of Disease. J. of the Nat. Cancer Inst. $22: 719-748,1959$.

[2] Cox, D. R., Regression Models and Life Tables. J. Stat. Soc. B 34, $187-220,1972$.

[3] R. R. Monson, Analysis of Relative Survival and Proportional Mortality. Comput. Biomed. Res. 7:325-332, 1974.

[4] R. J. Waxweiler, J. J. Beaumont, J. A. Henry, D. P. Brown, C. F. Robinson, G. 0. Ness, J. K. Wogoner, S. D. Hyg and R. A. Lemen, A Modified Life-Table Analysis System for Cohort Studies. J. of Occup. Medicine 25:115-124, 1983 .

[5] Mantel, N., Chi-square Tests with One Degree of Freedom. Extensions of the Mantel-Haensze1 Procedure. J. American Stat. Assoc. 58:690-700,1963.

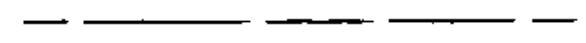

[6] McMichael, A. V., Standardized Mortality Ratios and the "Healthy Worker Effect": Scratching Beneath the Surface. J. of 0ccupational Medicine $18: 165-168,1976$.

[7] Gaffey, W. R., A Critique of the Standardized Mortality Ratio. J. of Occup. Medicine 18:157-160,1976.

[8] Cook, R. R., More Comments on the SMR. J. of Occup. Medicine 21:784-795, 1979.

[9] Enterline, P. E., Pitfalls in Epidemiological Research. J. of Occup. Medicine 18:150-156, 1976.

[10] Bryce, G. R., Data Analysis in Rummage - A User's Guide. Department of Statistics, Brigham Young University, 1980. 
[11] Baker, R. J., Nelder, J. A., The Glim Sygtem. Numerical Algorithms Group, 7 Bonbary Road, Oxford Ox $2,6 \mathrm{NW}, 1978$.

[12] Cramer, H., Mathematical Methods of Statistics. Princeton University Press, 227-231, 1945 .

[13] Miettinen, 0., Estimability and Estimation in Case-Referent Studies. American J. of Epidemiol. 103:226-235, 1976.

[14] Hakulinen, T., Mantel-Haenszel Statistic for Testing the Association Between a Polychotomous Exposure and a Rare Outcome. American J. of Epidemiol. 113:192-196,1981.

[15] Gilbert, E. S., Marks, S., An Analysis of the Mortality of Workers in a Nuclear Facility. Radiation Research 79:122-148, 1979.

[16] Tolley, H. D., Marks, S., Buchanan, J. A., Gilbert, E. S., A Further Update of the Analysis of the Mortality of Workers in a Nuclear Facility. Radiation Research 95:211-213, 1983. 


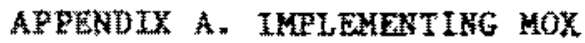

Fol low these steps to implement Mox on your VAX computer system:

Step 1. MOUNT THE MOX SOURCE TAPE

mount mt?: mox tape (? is your tape driwe designator, e.g. 0 or 1$)$

Step 2. CREXTE A SUBDTRETORY

createlatuctory [? aox] (a is your directory name)

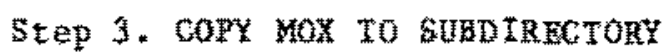

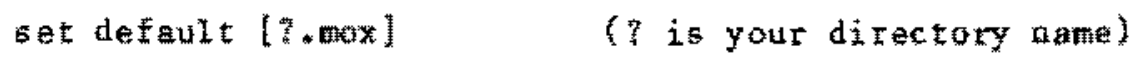

copy tape;*****

dismount tape

Step 4. COMPILE MOX

Gcompnox

Your subditectory should now contsia:

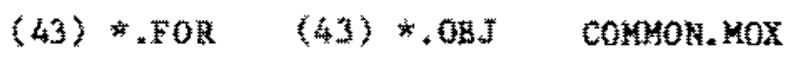

CONFMOX. CON WHEMOX.CON LINKMOX.OPT

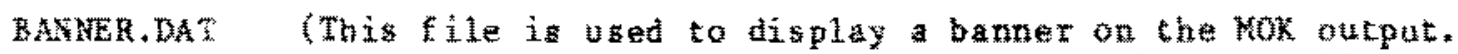
The sile way be aleted, or woved to a ditaterent dixectory i. a baner it not desired.)

Mox, DoC (This file contains the document you are reading.) 
The number of words of wetory required to perform partitular task is printed for each Mox analysts. If this Figure should exced the preset value of five hundred thousand ( $g$ ee Appendix $\mathrm{c}$ ), do the following:

1) Set the SPACE parametex in Commonox to a value greater than the number of words requized.

2) Rempomile wox by entering:

fecompmox

3) Re-link Mox by entering:

etinkmox

Allocating memory in this fashon allows Hox to divide all specified concrol variables into many wore categories than would otherwise be postible, even on a VAX (wher configured in the ugual Eashion). 
The following is an alphabetical listing of the software modules in Hox.

The function of each module is briefly degcribed and its entry points and external references are noted.

MODULE:

Alternate Entry Pointa:

Purpose:

Called from:

Calls To:

MODULE:

Alternate Entry Boints :

Puxpose:

Called from:

Calls To:

MODULE:

Purpose:

Called from:

References To:
AGEPRIY

CHPRIM, FURRIM

Determines primary group for age, calendar year or follow-up time

PRIMSEC

AGESEC

CYSEG, FUSEC

Determines secondary group for age, calendar year or follow-up time

FEIMSEC

ALPHAP

Prompts for a character mes aage of a specified length

PROMPT

NOFCHAR 
MODULE:

Puxpose:

Called From:

Calls To:

Reterences To:

MODULE:

Purpose:

Called Eran:

Calls ro:

MODULE:

Purpose:

Called From:

Calls To:

References To:

Momula:

Purpose:

Called From:

Calls To:

Reterence To:
BATCH

Reads processing specisications file created by Mox. Because the file may be edited by the user, it is screened for gros errors.

HOX

PRIMCV, SECCV

NOFCHER

CAUSES

Defines titles for cause of death catsegries Mox

COMAND

Creates a conmand lile from processing specicicatione

PROMPT

NUMER

NOFCHAR

\section{DEATHGEP}

Generates ammary based on grouped exposure $\operatorname{Mox}$

GINDEX, INVERSE, LEV ELS, PRIMSEC, SETIV2, SETEV4

NOE CHAR, NOHMAL. 
WODULE:

Puposes:

Called From:

Calls To:

References To:

NODULE:

Purpose:

Called From:

Callat To:

MODULE:

Purpoce:

Called Prom:

Gall To:

MODULE:

Alternate Entry Point:

Purpose:

Called Exom:

Galls To:

\section{DEATH IND}

Generates a summery based on ungrouped exposure

Mox

ATHDEX, LEVELS, PRIMSEC, SETIV2, SETRV 4

NOF THAR, NORMAL.

DIALOGUE

Defines prompta $\&$ helps

PROMPT

DIGITS

Determines of digits to allow for printing a real number

STRATTAB, TABLLE⿱

GINDEX

AINDEX

Determines control leyel index

DEATHGRP,DEATHIND, PROCESS, STRATTAB, TABLES 
Furpose:

Refarenced from:

References To:

MODUL:

Purpose:

Called from:

References To:

MODULE:

Purpose:

Cal Led Fron:

Calls To:

MODU LE:

Purpose:

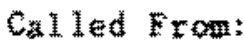

Callo To:

MODULE:

Fuxpose:

Called From:

Calls to:
Propto for an integer velue within a spacialied range

PROMPT

NOFCHAR

INTEREP

Promp for a wieb of integer values separated by comas

PROMPT

NOF CHAR

INTETAB

Prints integer table plus simple tokals STRATTAB, TABLES

SETIV4

\section{INVERSE}

Inverts $n-t h$ order matrix by the Jordan elimination method

DEATHERP

JOBCATG

Determines job category for a spectied job eode

SELECT 
MODULE:

Purpose:

Called From:

Calls To:

NODULE:

Purpose:

Calls To:

Feterences To:

MODVLE:

Purpose:

Referenced Erom:

KODU1 筆:

Eurpose:

Referenced From:

References To:
LEVELS

Determines control variable level

DEATHGRP, DEATHINL, PROCESS

Mox

Serves as the control point for all processing of a study group. Storage is allocated supporting wodules are referenced.

BA TCH, CADSES, DEALHGRF, DEATHIND, PROCESS, PKOMPT, SELECT, SETIVA, SETRV4, STRATTAB,TALES

SECOKD

NOFCHAR

Determines the of characters in a mesage ALPHAP, BATCA, COMMANO, DEATHGRP, DEATHIND, INTESERF, INTWREED, PROAPT, REALFREER, STRATTAB, TABLES, YEWOP

NOFAAL

Determines p-yalue of a normal tet statistic

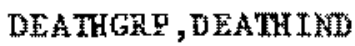


HODULE:

Furpose:

Called From:

Calds To:

MODULE:

Alternate Entry point:

Purpose:

Galled Frow:

Call Io:

MODULE:

Purpose:

Called From:

Calls To:

HODU LE:

Purpose:

Called From:

G11. To:
NUDB ER

Numbers group description promps

COMMAUD, RROMPT

PRIMCV

$\operatorname{SECCV}$

Deterwines primary of ocondary control variables

BATCH, PROMPT

PRIMSEC

Determines prinary $\&$ secondary group

DEATHGRP, DEATHIND, EROCESS

AGEPRIN,AGESEC,CYPRIH, CYSEC, FUPRIM, FUSEC

PROCES

Allocates person-years exposures by category to generake risk strata

Mox

ANDEX, GINDEX, LEVELS, PRIMSEC 
MODUL:

Purpose:

Called From:

Cal is To:

References To:

MODULE:

Purpone:

Called rom:

References To:

MODULE:

Purpose:

Called Fon:

C衤站 To:

MODULE:

Fumpose:

Called Eron:

Calls To:
PROAPT

Prompts uner for processing spectitutations screens them for errors

MOX

ALPHAP, COMMAND, DLALOGUE, IN TFREEP, NUACE ER, PRIMCV, REALFREEP, SECCV

INTERERP, NOFOHAR, YESNOP

REALF REEP

Prompts for a eries of real values separated by commas

PROMPT

NOFCHAR

REAL,TAB

Prints real table o mean totals

STEATTAB, TABLES

SETRY:

REALTAB

Prints real table weighted mean totals

STRATTAB

SER4 
MODULE:

Purpose:

Reterenced Erom:

Eeferences to:

MODULA:

Putpose:

Called from:

Calls To:

MODULE:

Eurpose:

Called From:

Cals To:

MODULE:

Pupose:

Called From:

Calis $\mathrm{To:}$

MODULE:

Purpose:

Galled Frow:

Calls To:
\$ECOND

Duma function to compersote for lack of epo library routine

MOX

SELECT

Selects cases oreateo subtiles per war specificatione

MOX

JOBCATE, SETRV4

SETIV

Initializes an integerk 2 yector

DEATHGRP, DEATYID

SETIVL

Initializes an integer $x^{*}$ yector

MOX,RISKTAE, ,

SETRV 4

Initializes a real*a vector

DEAMGRF, DEATKIND, HOX, PRIMTAB, SELECT, TABLES, TPRINTAB, TRISK TAB 
HODULE:

Purpose:

Celled Fran:

Calls To:

Reference To:

MODULE:

Purpoe:

Canlled From:

Callo To:

MODULE:

Purpose:

Cailed From:

Calis To:

ReEtences To:

MODULE:

Purpose:

fralled From:

Calis To:

\section{STRATTAB}

Prints tables stratified by all apecified control varizbles

Hox

AINDEX, DIGLTE, GINDEX, INTGTAB, REALTAB, EEAL VTAB, STRATTOT, VARTAB

NOF OHAR

STRATTOT

Brints tables of total for output stratified by all specified control yarables

STRATTAB

TIKTGTAB, TREALTAB

TABLES

printa tables stratified by prinary $\&$ secondary variables only

MoX

A INDEX, DIGITS, GINDEX, INTGTAB, REALTAB, SETRV4, TOTALS

NOFCHAR

\section{TINTETAB}

Prints total integer table plus simple totals BTRATTOT, TOTALS

SETIV 
MODLLLE:

Purpose:

Called From:

Callo To:

Monewe:

Purpose:

Called Fron:

Cal is To:

Monv1LE:

Purpose:

Galled From:

Calls To:

HODULE:

Purpose:

Referenced From:

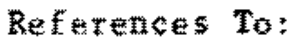

TOTALS

Prints tables ot totals for output atratisiea by primary ocondary variables only

TABLES

TREALTAB

THEXLTAB

Prints real total table plus simple totals STRATTOT, TOTALS

SETRV4

VARTAB

Prints exposure variance table STRATTAB

YESNOP

Prompte for response of yes or no

PRONPT

NOFCLA 
INTEGER $* 2$ CYR, DTHG , FUE, LEN, NCOD , NCODOCC, NDC, NDL, NICR, NICR2D THG , NQH , NRL, OCC, PRIM , SEC, STA, US E, XPO

INTEGER 4 SPACE, YRS

PARAMETER ( $C Y R=15, \mathrm{DTHG}=5, \mathrm{FUE}=15, \mathrm{LEN}=15, \mathrm{NCOD}=15, \mathrm{NDC}=86$,

$+$

$+$

$+$

PARAMETER（NCODOCC $=N C O D * O C C, N I C R 2 D T H G=N I C R * 2 * D T H G ）$

COMON / CASE / EXPOSURE(YRS), IBYR, ICAUSE, IDYR, IFYR,

+
+
+
+
+

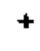
IUSEV4, IUS EV5, IYEMP, IYTERM, JOBCAT, JOBCODE

COMMON / CENTER/ NCCYR(CYR), NCFUE(FUE), NCLEN(LEN), NCOCC (OCC), NCPRIM, NCSEC, NCSTA(STA), NCUSE1 (USE), NCUSE2 (USE), NCUSE3 (USE), NCUSE4(USE), NCUSE5 (USE), NSECPR,

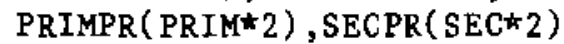
TABDTHMN, TABDTHSPC, TABPOW, TABS TRA T

COMMON / IDENTS/ BLANK, DASH, DASHES(NRL), CYRDESC(CYR), DTHCTGS (NDC), DTHDESC ( DTHG), EXPDESC, USE5DESC(USE) IUSE5X, LENGTH , NPRIMG ,NSECG
IHYR, IRACE, ISEX, IUSEV1, IUSEV2, IUSEV3,

COMMON / DEATHS/ AMU2(NDC), EXSUM(NDC), IRANGES(NICR, 2,DTHG), ND (NDC), NICDS (DTHG), OSUM(NDC), SCORES (XPO)

COMMON / GOVERN/ ABORT, ASCEND, ASSIGNSCR, BINARY, EOF, EQPCI, EQSCI, GROUP ED , IND IV , IN TACT, IS TDYE, IS TDYS, LAG , LA TENT, MOMENTS , ND THGRPS, NPRIMC, PNL , PRIMAGE, PRIMCY, PRIMFU, PRIMOWN, SECAGE, SECCY, SECFU, SECOWN, SENSITIVE, STRAT, STRATCYR, STRATFUE, STRATJ OB, STRA TLEN, STRATS TA, STRATUSE, STRATUSEl , STRATUSE2, S TRA TUSE3, S TRATU SE4, STRATU SE5, SUBS ET, TAB , TABDTH, FUEDESC ( FUE), LENDESC ( LEN), OCCDESC (OCC), PRIMDESC, SECDESC, S TADESC(STA), USE1 DESC (USE), USE2DESC(USE), USE3 DESC(USE), USE4DESC(USE),

COMMON / INDEX / IAGE, ICYEAR, ICYRX, IFUEX, IFUP, IGRPX, ILENX, INDEXA, INDEX G, IOCCX, IS TAX, IUSEIX, IUSE2X, IUSE3X, IUSE4X,

COMMON / LIMIT / EGMN(XPO), ICYR(CYR), IFUE (FUE), ILEN(LEN), IOCC (NCOD, OCC), IPRIM( PRIM), ISEC( SEC), ISTA(STA), IUL, IUSEl (USE), IUSE2 (USE), IUSE3 (USE), IUSE4 (USE), IUSE5 (USE), NCODES ( OCC), NOING (XPO), REXP(XPO)

ऋ The SPACE parameter may be increased (see Appendix A).

**IRACE and ISEX are included for a special purpose and do not need to be defined by the user 


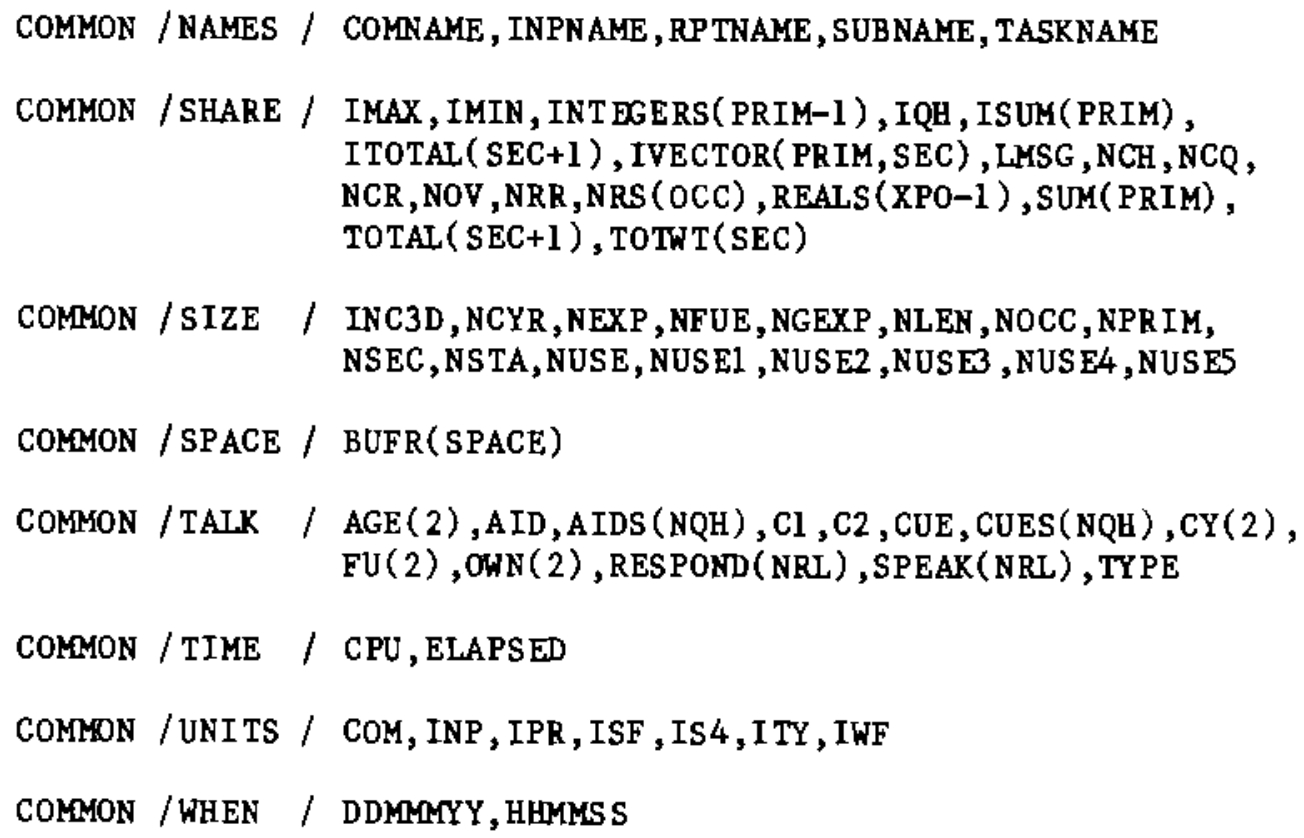
ITOTAL ( SEC+1), IVECTOR( PRIM, SEC), LMSG, NCH, NCQ, NCR , NOV , NRR , NRS (OCC), REALS (XPO-1), SUM( PRIM), TOTAL (SEC+1), TOTWT(SEC)

COMMON /SIZE / INC3D, NCYR, NEXP, NFUE, NGEXP, NLEN, NOCC, NPR IM, NSEC, NSTA, NUSE, NUSE1, NUSE2, NUSE3, NUSE4, NUSES

COMMON / SPACE / BUFR(SPACE)

COMMON / TALK / AGE (2), AID, AIDS(NQH), Cl, C2, CUE, CUES(NQH), CY(2), FU (2), OWN(2), RESPOND(NRL), SPEAK(NRL), TYPE

COMMON / TIME / CPU, ELAPSED

COMMON /UNI TS / COM, INP, IPR, ISF, IS4, I TY, IWF

COMMON /WHEN / DDMMYY, HHMMS S

REAL*4 CASE(YRS+1 7), NORMAL

EQUYVALENCE (CASE, EXPOSURE), (RESPOND, RESPONSE)

INTEGER 2 COM, IAGE, IBYR, ICYEAR, ICYR, ICYRX, IDYR, IFUE, IFUEX, IFUP, IFYR, IGRPX, IHYR, ILEN, ILENX, IMAX, IMIN, INP, INTEGERS, IOCC, IOCCX, IPR, I PRIM, IQH, IRACE, IRANGES, ISEC, IS EX, ISF, IS TA, IS TAX, IS TDYE, IS TDYS, IS4, I TY, IUEGP, IUL, IUSE1, IUSE2, IUSE3, IUSE4, IUSE5, IYEMP, IY TERM, JOB CA T, LAG, LATENT, LENGTH, LMSG, NCCYR, NCFUE, NCH , NCLEN, NCOCC, NCODE S, NC PRIM, NCQ , NCR, NCS EC, NCS TA, NCUSEl, NCUSE2, NCUSE3, NCUSE4, NCUSE5, NCYR, ND, NFUE, NGEXP , NICDS , NLEN, NOCC, NOF CHAR, NOV ,NPRIMG , NSECG , NSECPR, NSTA , PRIMPR, SECPR

LOGICAL 1 ABORT, ASCEND, AS SIGN SCR, BANNER, BINARY, EOF, EQPCI, EQSCI, GROUP ED , INDIV , IN TACT , MOMENTS, PNL , PRI MAGE, PRIMCY, PRIMFU, PRIMOWN, SECAGE, SECCY, SECFU, SECOWN, SENSITIVE, STRAT, S TRATCYR, STRATFUE, STRATJOB , STRA TLEN, S TRATS TA, STRATUSE, STRATUSEl , STRA TUS E2, STRATUSE3, STRATUSE4, S TRATUSE5, SUB SET, TAB, TABDTH, TABDTHMN , TABDTH SPC, TABPOW, TABS TRAT, YESNOP

CHARACTER AGE* $3, A I D *(N R L), A I D S *$ (NRL), BLANK, C1 , C2, COMNAME* (NRL), CUE* (NRL), CUES* (NRL), CY*13, CYRDESC * (NDL), DASH, DASHES, DDMMMY* 9 , DTHCTGS* (NRL), DTHDESC * (NRL), EXPDESC* (NDL),FU* 14, FUEDESC* (NDL), HHMMS $S^{\star} 8$, INPNAME* (NRL), LENDESC* (NDL), LINE $\star 132$, OCCDESC $\star$ (NDL), OWN*3, PRIMDESC $\star$ (NDL), RESPOND, RESPONSE* (NRL), RPTNAME* (NRL), SECDESC* (NDL), SPEAK, STADESC* (NDL), SUBNAME* (NRL), TASKNAME* (NRL), TYPE* 8 , USEIDESC* (NDL), USE2DESC* (NDL), USE3DESC* (NDL), USE4DESC $\star$ (NDL), USE5DESC $\star$ (NDL) 


\section{APPENDIX D. STUDY GROUP FORMAT}

\begin{tabular}{|c|c|}
\hline Record & Leng th \\
\hline 1 & 9 \\
\hline 1 & 7 \\
\hline 1 & 1 \\
\hline 1 & 1 \\
\hline 1 & 7 \\
\hline 1 & 7 \\
\hline 1 & 1 \\
\hline 1 & 5 \\
\hline 1 & 5 \\
\hline 1 & 5 \\
\hline 1 & 5 \\
\hline 1 & 5 \\
\hline 1 & 5 \\
\hline 1 & 5 \\
\hline
\end{tabular}

\begin{tabular}{ll} 
Specification & Column \\
\cline { 1 - 1 } I9 & $1-9$ \\
F7.3 & $10-16$ \\
I1 & 17 \\
I1 & 18 \\
F7.3 & $19-25$ \\
F7.3 & $26-32$ \\
I1 & 34 \\
F5.0 & $43-47$ \\
" " & $48-52$ \\
" " & $53-57$ \\
" " & $58-62$ \\
" " & $63-67$ \\
" " & $68-72$ \\
& $73-77$
\end{tabular}

Field Identification

Research \# exact Birth Date - 1900 Sex

Race

exact Employment Date - 1900 exact Termination "

Job Category code 1944 Exposure in centirems $1945 "$ $1946 "$

$1947 "$

$1948 "$

$1949 "$

$1950 "$

\begin{tabular}{|c|c|c|c|c|c|}
\hline Record \# & Length & Specification & Columns & & Pield Identification \\
\hline 2 & 5 & F5.0 & $1-5$ & 1951 & Exposure in centirem \\
\hline 2 & 5 & 111 & $6-10$ & 1952 & " \\
\hline 2 & 5 & " " & $11-15$ & 1953 & If \\
\hline 2 & 5 & " " & $16-20$ & 1954 & $" 1$ \\
\hline 2 & 5 & $" \quad "$ & $21-25$ & 1955 & $"$ \\
\hline 2 & 5 & 11 & $26-30$ & 1956 & $"$ \\
\hline 2 & 5 & $" 11$ & $31-35$ & 1957 & $" \prime$ \\
\hline 2 & 5 & 1111 & $36-40$ & 1958 & $" 1$ \\
\hline 2 & 5 & " " & $41-45$ & 1959 & $"$ \\
\hline 2 & 5 & " " & $46-50$ & 1960 & $"$ \\
\hline 2 & 5 & " " & $51-55$ & 1961 & $"$ \\
\hline 2 & 5 & $" 1 "$ & $56-60$ & 1962 & $"$ \\
\hline 2 & 5 & $" 1$ & $61-65$ & 1963 & $"$ \\
\hline 2 & 5 & " 1 & $66-70$ & 1964 & $" 1$ \\
\hline 2 & 5 & 111 & $71-75$ & 1965 & " \\
\hline 2 & 5 & " " & $76-80$ & 1966 & " \\
\hline
\end{tabular}




\begin{tabular}{|c|c|c|c|c|c|}
\hline Record \# & Length & Specification & Columns & & Field Identification \\
\hline 3 & 5 & F5.0 & $1-5$ & 1967 & Exposure in centirens \\
\hline 3 & 5 & & $6-10$ & 1968 & " \\
\hline 3 & 5 & 11 & $11-15$ & 1969 & $"$ \\
\hline 3 & 5 & $" 1$ & $16-20$ & 1970 & $"$ \\
\hline 3 & 5 & $" 1 "$ & $21-25$ & 1971 & $u$ \\
\hline 3 & 5 & 11 & $26-30$ & 1972 & $"$ \\
\hline 3 & 5 & $" 11$ & $31-35$ & 1973 & $"$ \\
\hline 3 & 5 & $" 1 "$ & $36-40$ & 1974 & $"$ \\
\hline 3 & 5 & 11 & $41-45$ & 1975 & $1 "$ \\
\hline 3 & 5 & $" \quad "$ & $46-50$ & 1976 & 1 \\
\hline 3 & 5 & 11 & $51-55$ & 1977 & 1 \\
\hline 3 & 5 & 11 & $56-60$ & 1978 & 11 \\
\hline 3 & 2 & I2 & $61-62$ & \# of & Exposure Readings \\
\hline 3 & 2 & I2 & $63-64$ & $1 \mathrm{st}$ & Year of Exposure -1900 \\
\hline 3 & 2 & I2 & $66-67$ & 2nd & " \\
\hline 3 & 2 & I2 & $68-69$ & $3 \mathrm{rd}$ & $"$ \\
\hline 3 & 2 & 12 & $70-71$ & Lest & $\because "$ \\
\hline
\end{tabular}

\begin{tabular}{|c|c|c|c|c|}
\hline Record \# & Length & Specification & Columns & Field Identification \\
\hline $\begin{array}{l}4 \\
4\end{array}$ & $\begin{array}{l}7 \\
4\end{array}$ & $\begin{array}{l}\mathrm{F} 7.3 \\
\mathrm{I} 3\end{array}$ & $\begin{array}{l}28-34 \\
42-44\end{array}$ & $\begin{array}{l}\text { exact Death Date - } 1900 \\
\text { ICD Cause of Death code }\end{array}$ \\
\hline
\end{tabular}


SUBROUTIKE SELECT

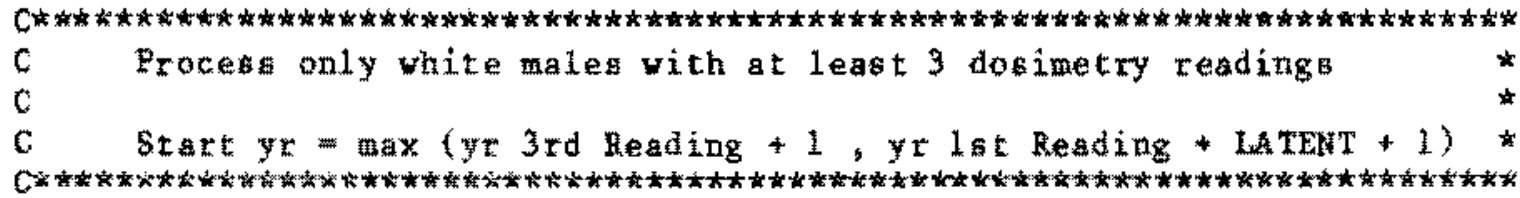

INCLWOE 'COMHON , HOX NOLIST

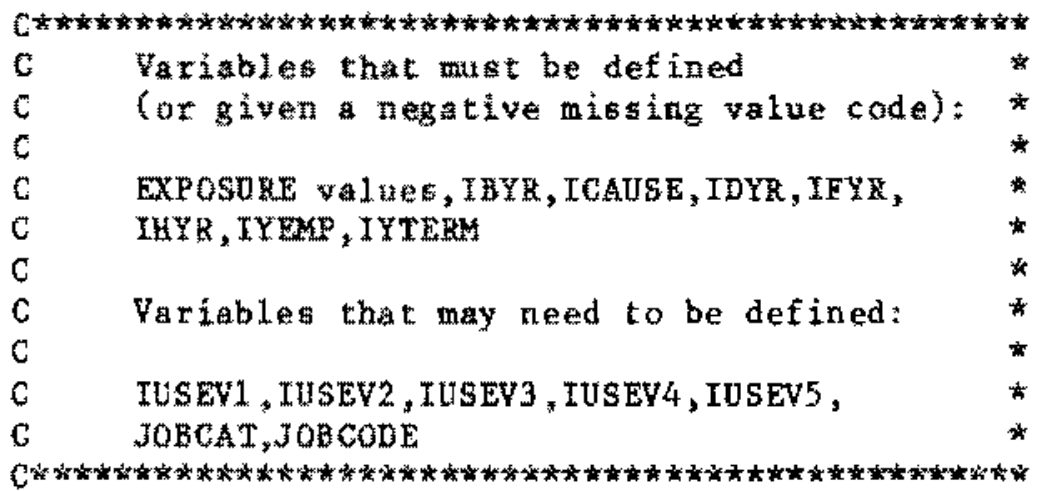

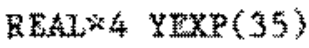

c-m-m-3e end of tile indicator

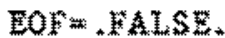

C-m-m-2ero exposure vector

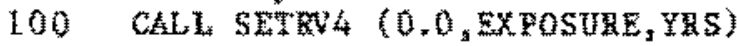

Com-- - Fortated input file? IF (BWAEY) CO TO 300

C---Yes... read a case READ (INP, 800, END=700) IRESN, YOB, ISEX, IRACE, YOH, YOF, JOBCODE, $+(Y \operatorname{EXP}(I), I=1,35)$, NONR, IFS TDS, ISCNDS, I THEDS, ILSTDS, YOD, IDCONE

C.--n........-... Transform yearly exposures into cumulative exposures DO $200 \quad I=2,35$ EXPOSURE (I) MAX(YEXP(I-1),0.0)+EXPOSURE(I-1) 


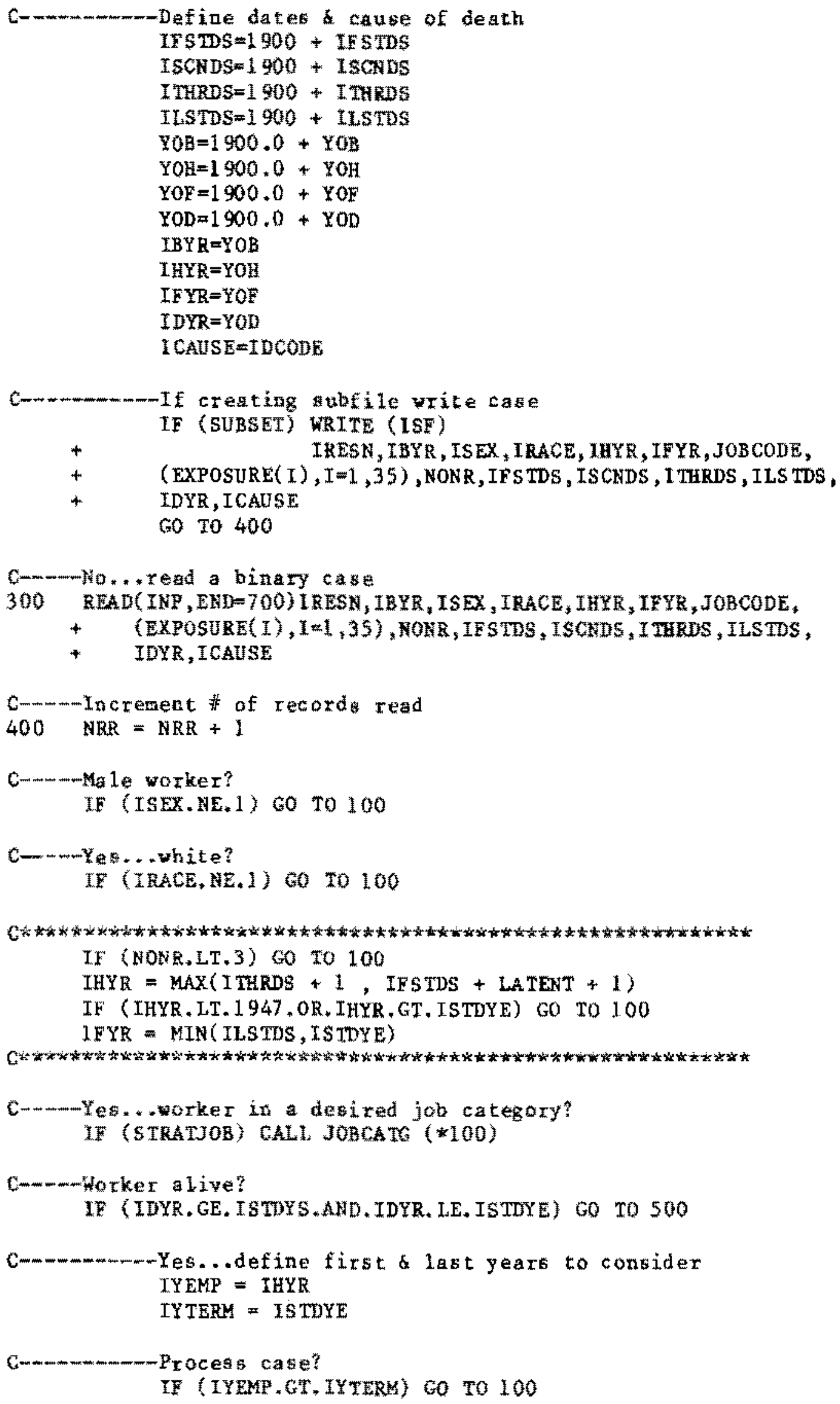




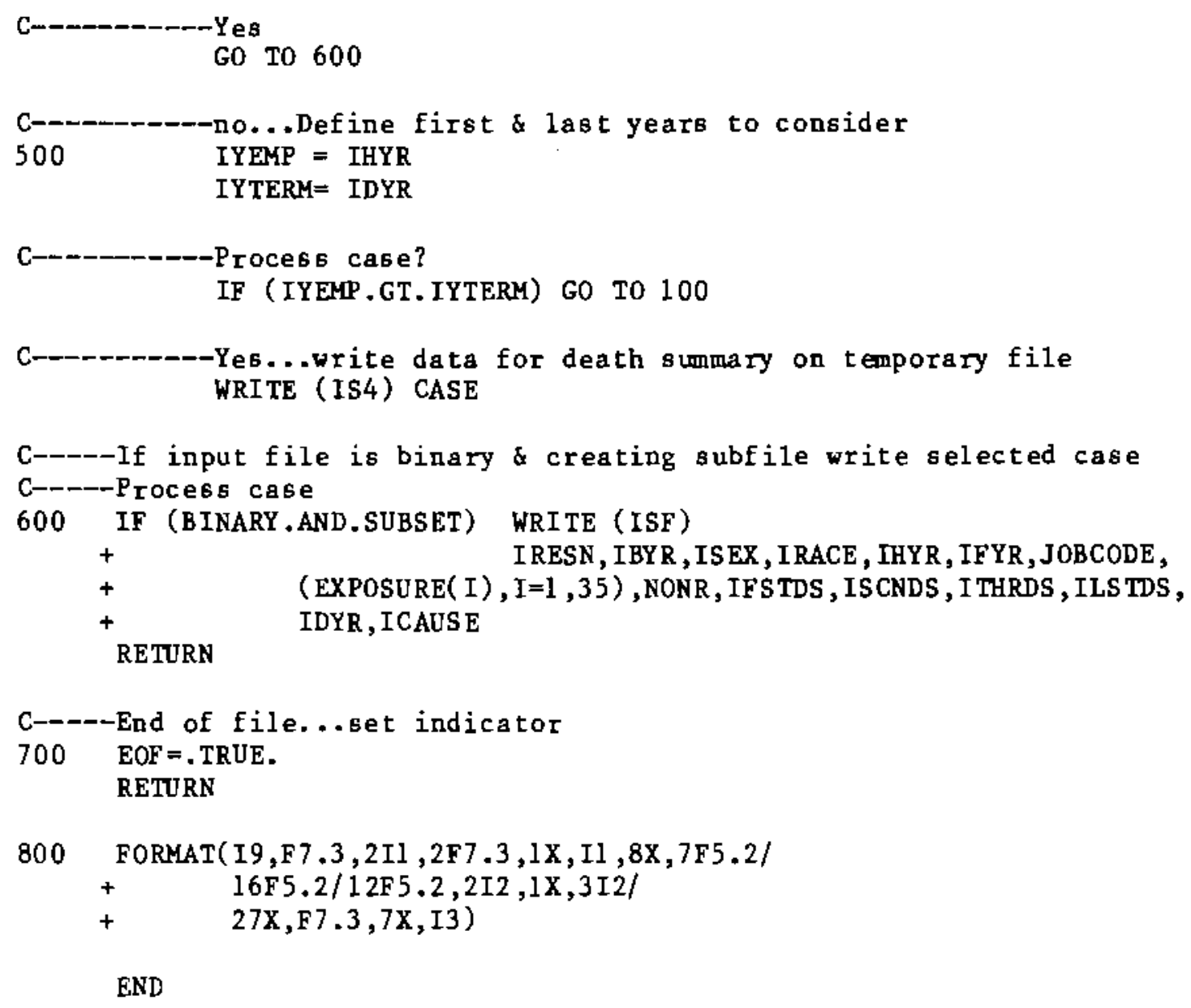

END 
.

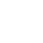

.

.

. 
(MOX PROMPTS ARE PRINTED IN UPPER CASE)

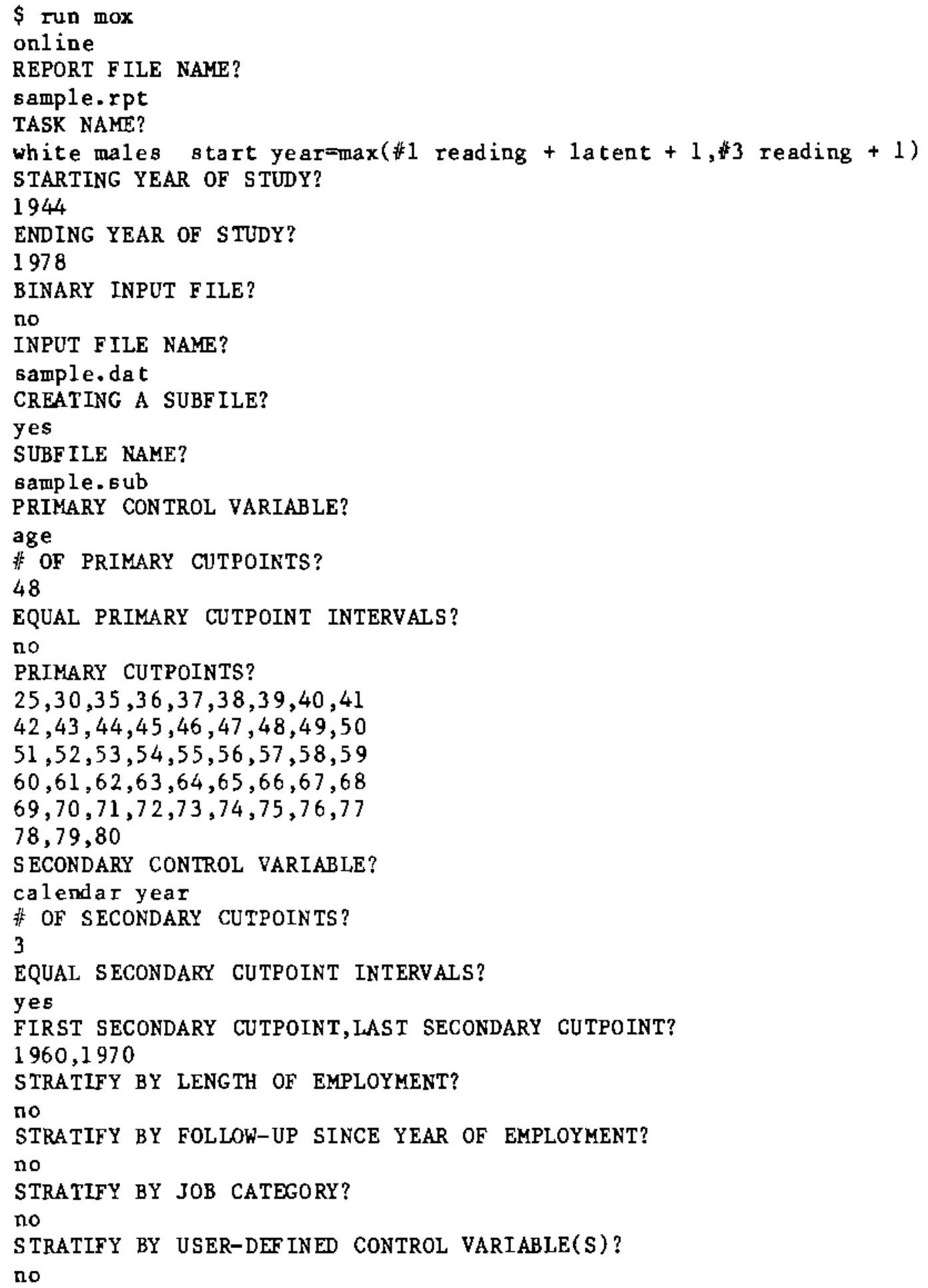


OF EXPOSURE cUTPOINTS?

3

Exposuke CUTPONT(\$)

$2 ., 5 * \ldots 5$.

DESCRI TTION OF EXPOSUKE UNTLE?

rema

LATENCY FERIOD FOR EXPOSURE?

10

PRINT TABLES OF DEATHS FROM ALL CAUSES?

yes

PRINT TAELES OF DEATHS FROM ALL MALIGNANT NEORLASMS?

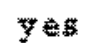

BRINT TAELES FOR OTHER SPECTRTED CALSES OE DEATH

Yes

* OF OTHER DEATH TABLES

1

N OF TCD CODE RANGES IN DEATH TABLE 1 ?

1

LOWER, UPPER RANGE OF CODES IN DEATH TABLE 1?

162.162

DEATH TABULATION DESGRTPTION FOE TABLE 1\%

lung cancer (162)

DRINT POWER TOTALS?

yes

PRINT UNGROUPED EXPOSURE ANALYSIS KESULTS?

yes

PRTNT GROUPED EXPOSURE ANALISTS RESULTS?

yes

ASSIGN SCORES TO THE EXPOSURE CATEGORIES?

no

COMKAND FLLE RAME?

sample. com

INPUT SPECIFICATIONS HAVE BEEN RECORDED ON sample, com

PERFORM INTERACTIVE ANALYSIS PER SPECIFICATIONS?

no

MOX ELISHEO 
(The name of this file is sample.com)

\$ SD . MOX

$\$$ RUN MOX

batch

REPORT FILE NAME?

any valid $f$ ile name up to 80 characters

sample. rpt

TASK NAME?

1 to 80 characters

white males start yearfmax (\#1 reading + latent +1 , \#3 reading +1 )

STARTING YEAR OF STUDY?

any 4 digit integer

1944

ENDING YEAR OF STUDY?

4 digit integer $<0 R=$ starting year of $s$ tudy +50

1978

BINARY INPUT FILE?

yes OR no

no

INPUT FILE NAME?

any valid file name up to 80 characters

sample.dat

CREATING A SUBEILE?

yes $O R$ no

yes

SUBF ILE NAME?

any valid file name up to 80 characters

sample.sub

PRIMARY CONTROL VARIABLE?

SPECIFY age, calendar year, OR follow-up time

age

\# OF PRIMARY CUTPOINTS?

an integer between $2 \& 49$ inclusive

48

EQUAL PRIMARY CUTPOINT INTERVALS?

yes OR no

no

FIRST PRIMARY CUTPOINT, LAST PRIMARY CUTPOINT?

(last-first integer values)/( \# primary cutpoints-1) must = an integer 0025,0080 


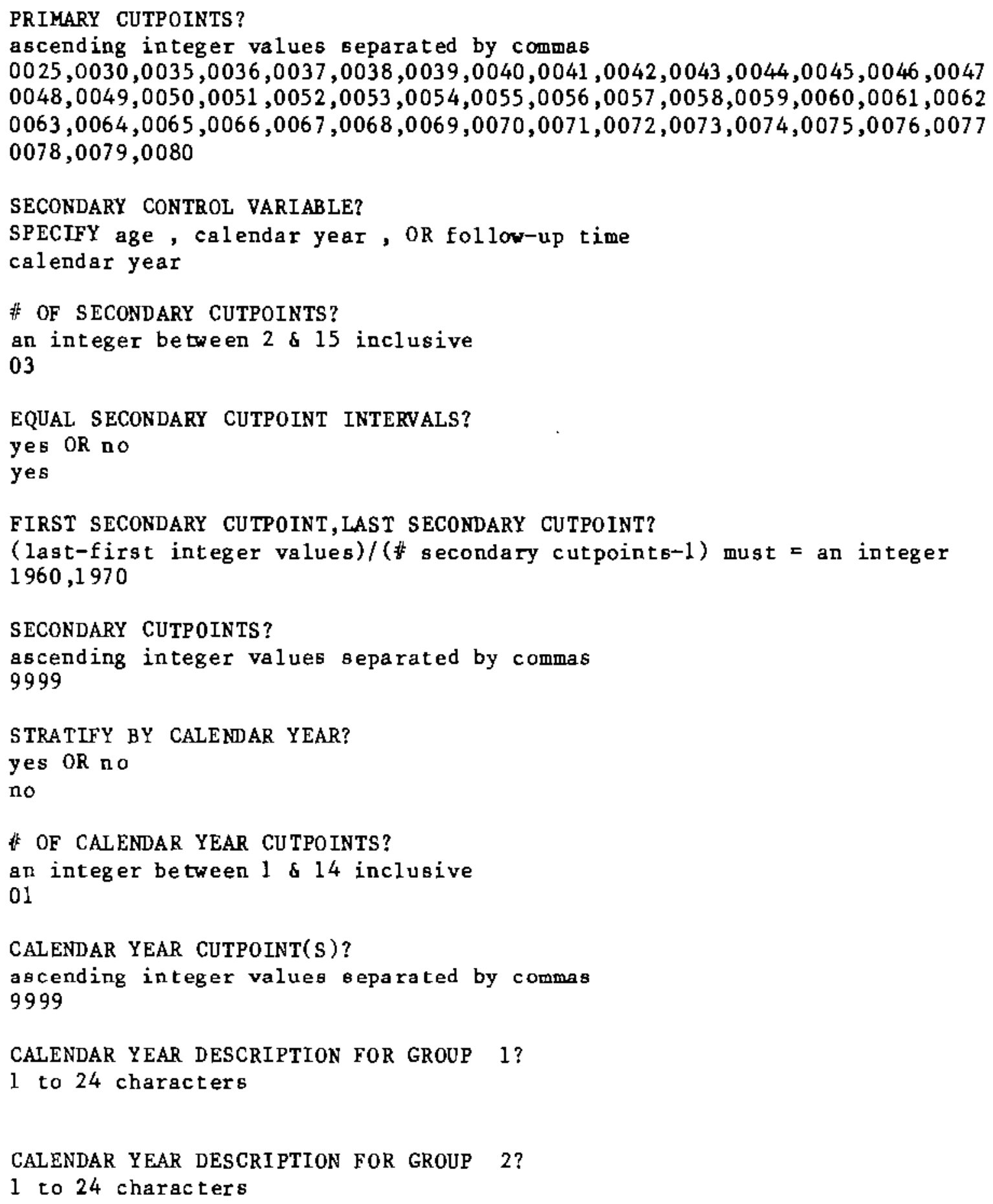


CALENDAR YEAR DESCRIPTION FOR GROUP 5 ?

1 to 24 characters

CALENDAR YEAR DESCRIPTION FOR GROUP 6?

1 to 24 characters

CALENDAR YEAR DESCRIPTION FOR GROUP 7 ?

1 to 24 characters

CALENDAR YEAR DESCRIPTION FOR GROUP 8?

1 to 24 characters

CALENDAR YEAR DESCRIPTION FOR GROUP 9?

1 to 24 characters

CALENDAR YEAR DESCRIPTION FOR GROUP 10 ?

1 to 24 characters

CALENDAR YEAR DESCRIPTION FOR GROUP 11 ?

1 to 24 characters

CALENDAR YEAR DESCRIPTION FOR GROUP 12 ?

1 to 24 characters

CALENDAR YEAR DESCRIPTION FOR GROUP 13 ?

1 to 24 characters

CALENDAR YEAR DESCRIPTION FOR GROUP 14 ?

1 to 24 characters

CALENDAR YEAR DESCRIPTION FOR GROUP 15 ?

1 to 24 characters

STRATIFY BY LENGTH OF EMPLOYMENT?

yes OR no

no

\# OF LENGTH OF EMPLOYMENT CUTPOINTS?

$a n$ integer between 1 \& 14 inclusive

01 
LENGT of EMPLOYMENT CUTPOINTS 5 ?

ascending integer velud betratat by commas

999

LENGTH OF EMPLOYMNT DESCRIPTION FOR GROUP 1 ?

1 to 24 characters

LENGTH OF EMPLOYMENT DESCRIPTION FOR GROUP 2 ?

1 to 24 characters

LENGTH OF GMPLOYNENT DESERTETION FOR GROUP 3 ?

I to 2 . characters

LENGTH OF EMPLOYMENT DESCRTPTION FOR GROUP 4 ?

1 to 24 characters

IENG TH OF EMPLOYMENT DESCRIPTION FOR GROUP 5 ?

1 to 24 characters

LENGTH OE EMPLOYMENT DESCR IPTION FOR GROUP G\%

1 to 24 characters

LENGTH OF EMPLOYMENT DESCRTPTION FOR GROUP $7 ?$

I to 24 characters

LENGTH OF EMPLOYMENT DESCEIITTON FOR GROUP B?

1 to 2 characters

LENGTA OF EMPLOYMENT DESCR TPTION FOR GROUP 3 ?

l to 24 characters

LENGTH OF EMPLOYMENT DESCRIPTION FOR GROUE IO?

I to 2 is characters

LENCH ON ENLLYNENT DESCRIPTION FOR GROUP 11 ?

1 to 24 characters

LENG TH OF EMPLOYMENT DESCRIPTION FOR GROUP 12 ?

1 to 24 characters

LENG TH GF EMLOYKENT DESCRIPTION FOR GROUP 137

1 to 2 a characters 
LENGTH OF EMPLOYMENT DESCRIPTION FOR GROUP 14 ?

1 to 24 characters

LENGTH OF EMPLOYMENT DESCRIPTION FOR GROUP 15?

1 to 24 characters

STRATIFY BY FOLLOW-UP SINCE YEAR OF EMPLOYMENT?

yes OR no

no

\# OF FOLLLW-UP CUTPOINTS?

an integer between $1 \& 14$ inclusive

01

FOLDW-UP CUTPOINT(S)?

ascending integer values separated by commas

9999

FOLLOW-UP DESCRIPTION FOR GROUP 1 ?

1 to 24 characters

FOLLOW-UP DESCRIPTION FOR GROUP 2?

1 to 24 characters

FOLLOW-UP DESCRIPTION FOR GROUP 3?

1 to 24 characters

FOLLOW-UP DESCRIPTION FOR GROUP 4?

1 to 24 characters

FOLLOW-UP DESCRIPTION FOR GROUP 5?

1 to 24 characters

FOLLOW-UP DESCRIPTION FOR GROUP 6 ?

1 to 24 characters

FOLLOW-UP DESCRIPTION FOR GROUP 7?

1 to 24 characters

FOLLOW-UP DESCRIPTION FOR GROUP 8?

1 to 24 characters

FOLLOW-UP DESCRIPTION FOR GROUP 9?

1 to 24 characters 
FOLLOW-UP DESCRIPTION FOR GROUP 10?

1 to 24 sharacters

FOLIOW-UP DESCRIPTION FOR GROUP 11?

1 to 24 characters

FOLLOW-UP DESCRIPTION FOR GROUP 12 ?

1 to 24 characters

FOLLOW-UP DESCRIPTION FOR GROUP 13 ?

1 to 2 a characters

FOLLOWWUP DESCRIETION FOR GROUP 14 ?

1 to 24 characters

FOLTOW-UE DESCRIPTION FOR GROU $15 ?$

1 to 24 characters

STKATIFY HY JOL CATECORY?

yes $\mathrm{OR} \mathrm{no}$

no

* OF JOB CATFGORIES?

an integer between 2 \& 15 inclusive

02

H OF CODES IN JOD CATHORY I?

an integer between 1 å 15 inclusive

01

CODES IN JOE CATEGOR $1:$

integer values eparated by commas 9999

DESCRETTON WOR JOE CATECORY 1 ?

1 to 2 a chatateres

* OF CODES IN JOB CATEGOLE 2?

an integer between 1 \& 15 inclusive O1

CODES IN JOB CATECORY 2 ?

integer values aparated by commas 9999

DESCRIPTHON FOR JOB CATEGORY 27

I to 24 characters 
* OE CODE HN JOE CATEORE 3?

an inceser leten 1 \& 15 inclusive

0 i

CODES IN JOA CATECORY 3?

integer yalue separated by commas

9999

DESCRIETION FOR JOB CATEGORY 3?

1 to 24 characters

4 OF COIES IN JOB CATEGORY 4 ?

an integer between 1 a 15 inclusive

ol

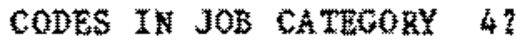

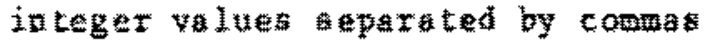

9999

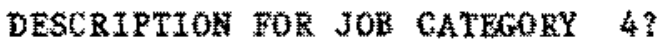

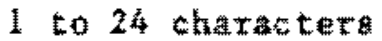

* OP CODES IN JOH CATEGORY 5 ?

an integer between 1 \& 15 inclueive

01

CODES IN JOB CATEGORY 5 ?

integer values separated by comma

9999

DESCRIETION FOR JOB CATEGORY 5 ?

1 to 24 charactestats

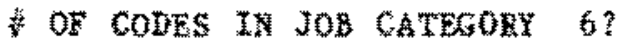

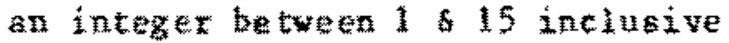

01

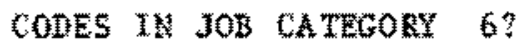

integer values separated by comma 990

DESCREDTON FOR JOB CATEOORY 6?

10024 chatacters

\# OF CODES IN JOB CATEGORY 7?

an integer between 1 . 15 inclusive

01

CODES IN JOB CATEGORY 7 ?

integer voluet ceparated by commat 999 
DESCRIFTION FOR JOB CATECORY 7?

1 to 24 sharecters

\# OF CODES TH JOB CATEGOR 8 ?

an integer between 1. 15 incluaive

ol

CODES IN JOB CATEGORY B?

integer values separated by commas 9999

DESCKIPTION FOR JOB CATEGORY 8?

1 to 24 ehazacter

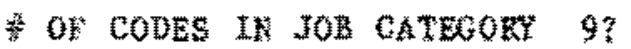

an integer betwen 1 \& 15 inclusive

0

CODES IN JON CATECORY $9 ?$

integer values separated by commas 9999

DESCRIFTION FOK JOB CATESOHY 9 ?

1 to 24 chartacter

\# OF CODES IN JOB CATEGORY 10 ?

an integer between 1 \& 15 inclusive 01

CODES IN JOW CATECONY 10 ?

integer valueb separated by commas 9999

DESCRTPTION FOR JOB CATEGORY 10 ?

1 to 2 a chatate totes

3 OF COUES IH JOS CATECON 11?

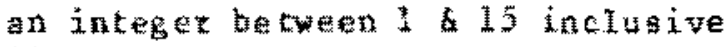

01

CODES IN JOB CATEGORY I?

integer values separated by coumas 9999

DESCRIPTTON FOR JOB CATEGORY 11 ?

1 to 24 characters

* OF CODES IN JOB CATEGORY 12 ?

an integet between 1 \& 15 inclusive

01 
CODES IN JOB CATEGORY 12 ?

integer vilues separsted by commas 9999

DESCRIPTION FOR JOB CATEGORY 12?

1 to 24 characters

\# OF CODES IN JOB CATEGORY 13 ?

an integer between $1 \& 15$ inclusive

01

CODES IN JOB CATEGORY 13?

integer values separated by commas 9999

DESCRIPTION FOR JOB CATEGORY 13 ?

1 to 24 characters

\# OF CODES IN JOB CATEGORY 14?

an integer between 1 \& 15 inclusive

01

CODES IN JOB CATEGORY 14 ?

integer values separated by commas 9999

DESCRIPTION FOR JOB CATEGORY 14 ?

1 to 24 characters

\# OF CODES IN JOB CATEGORY 15?

an integer between $1 \& 15$ inclusive

01

CODES IN JOB CATEGORY 15?

integer values separated by commas

9999

DESCRIPTION FOR JOB CATEGORY 15?

1 to 24 characters

STRATIFY BY USER-DEFINED CONTROL VARIABLE(S)?

yes OR no

no

\# OF USER-DEFINED CONTROL VARIABLES?

an integer between $1 \& 5$ inclusive

01

\# OF CONTROL VARIABLE 1 CUTPOINTS?

an integer between 1 \& 14 inclusive

01 
CONTROL VARIABLE 1 CUTPOINT(S)?

ascending integer values separated by comman 9999

CONTROL VARIABLE 1 DESCRIPTION FOR GROUP 1 ?

1 to 24 characters

CONTROL VARIABLE I DESCRIPTION FOR GROUP 2 ?

1 to 24 characters

CONTROL VARIABLE 1 DESCRIPTION FOR GROUP 3 ?

1 to 24 characters

CONTROL VARIABLE 1 DESCRIPTION FOR GROUP 4?

1 to 24 characters

CONTROL VARIABLE 1 DESCRIPTION FOR GROUP 5 ?

1 to 24 characters

CONTROL VARIABLE 1 DESCRIPTION FOR GROUP 6 ?

1 to 24 characters

CONTROL VARIABLE 1 DESCRIPTION FOR GROUP 7?

1 to 24 characters

CONTROL VARIABLE 1 DESCRIPTION FOR GROUP 8 ?

1 to 24 characters

CONTROL VARIABLE 1 DESCRIPTION FOR GROUP 9 ?

1 to 24 characters

CONTROL VARIABLE 1 DESCRIPTION FOR GROUP 10 ?

1 to 24 characters

CONTROL VARIABLE 1 DESCRIPTION FOR GROUP 11 ?

1 to 24 characters

CONTROL VARIABLE I DESCRIPTION FOR GROUP 12 ?

1 to 24 characters

CONTROL VARIABLE 1 DESCRIPTION FOR GROUP 13?

1 to 24 characters 
CONTROL YARIABLE I DESERIPTION YOR GROUP 14?

1 to 2 a characters

CONTKOL VARIABLE 1 DESCRTPTION FOR GROUP I5?

1 to 24 characters

\$ OF CONTROL VARIABLE 2 CUTPOINTS?

an ateger between $1 \% 14$ inelusive

01

CONTHOF YARTALE 2 CUTPOLNT(S)?

ascending integer values separated by commas 9999

CONTKOL VARIABLE 2 DESCRIPTION FOR GROUP 1 ? 1 t. 24 characters

CONTROL YARIABLE 2 DESGRIPTION FOR GROUP 2 ? 1 to 2 a characters

CONTROL VARIABLE 2 DESCRIPTYON FOR GROUP 3 ? 1 to 24 characters

CONTROL VARIABLE 2 DESCRIPTION FOR GROUP 4? 1 to 24 characters

CONTROL VARIABLE 2 DESCRIPTION FOR GROUP $5 ?$ 1 to 2 atis characters

CONTROL VARIABLE 2 DESCRLPTION FOR GROUP 6? 1 to 24 characters

CONTROE YARIABLE 2 DESCRIPTTON FOR GROUP 7? I to 24 characters

CONTKOL VARTABLE 2 DESCERTTION FOR GROUP B\% 1 to 2 a chracters

CONTROL VARIABLE 2 DESCRIPTION FOR GROUP $9 ?$ 1 to 24 characters

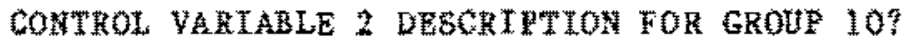
1 to 2 chacters 
CONTROL VARLARLE 2 DESCRIPTION FOR GROUP IL

1 to 24 chatactert

CONTROL VARIABLE 2 DESCRIETION FOR GROUP 12 ?

1 to 24 characters

CONTROL VARIABLE 2 DESCRIPTION FOR GROUP $13 ?$

1 to 24 characters

CONTROL VARIABLE 2 DESGRIPTION FOR GROUP 14?

1 to 24 characters

CONTROL VARTABLE 2 DESCRIPTION FOR GROUP $15 ?$

1 to 2 a characters

* OF CONTKOL VARLABLE 3 CUTEOTNTS?

an integer between 1 a 14 incluaive

ol

CONTROL VARLABLE 3 CUTPOINT(S)?

ascending integer values separated by commas 9999

CONTROL VARIARLE 3 DESCRIPTION FOR GROUP 1 ?

1 to 24 characters

CONTROL VARIABLE 3 DESCRIPTION FOR GROUP 2 ?

1 to 24 characters

CONTROL WARIAEL筑 3 DESCR IDTION FOR GROUP 3 ?

1 to 24 characters

CONTROL VARTAELE 3 DESCRIPTION FOR GROUP 4 ?

1 to 24 characters

CONTROL VARLAELE 3 DESCRIFTION FOR GROUP 5 ?

1 to 24 tharacters

CONTROL VARIABLE 3 DESCRIPTION FOR GROUP 6 ?

1 to 24 characters

CONTROL VARIABLE 3 DESCRIPTION FOR GROUP 7 ?

1 to 24 characters 
CONTROL VARIABLE 3 DESCRIPTION FOR GROUP 8 ?

1 to 24 characters

CONTROL VARIABLE 3 DESCRIPTION FOR GROUP 9 ?

1 to 24 characters

CONTROL VARIABLE 3 DESCRIPTION FOR GROUP 10 ?

1 to 24 characters

CONTROL VARIABLE 3 DESCRIPTION FOR GROUP 11 ?

1 to 24 characters

CONTROL VARIABLE 3 DESCRIPTION FOR GROUP 12 ?

1 to 24 characters

CONTROL VARIABLE 3 DESCRIPTION FOR GROUP 13 ?

1 to 24 characters

CONTROL VARIABLE 3 DESCRIPTION FOR GROUP 14 ?

1 to 24 characters

CONTROL VARIABLE 3 DESCRIPTION FOR GROUP 15 ?

1 to 24 characters

\# OF CONTROL VARIABLE 4 CUTPOINTS?

an integer between $1 \& 14$ inclusive

01

CONTROL VARIABLE 4 CUTPOINT(S)?

ascending integer values separated by commas 9999

CONTROL VARIABLE 4 DESCRIPTION FOR GROUP 1 ?

1 to 24 characters

CONTROL VARIABLE 4 DESCRIPTION FOR GROUP 2 ? 1 to 24 characters

CONTROL VARIABLE 4 DESCRIPTION FOR GROUP 3 ?

1 to 24 characters

CONTROL VARIABLE 4 DESCRIPTION FOR GROUP 4 ? 1 to 24 characters 
CONTROL VARTABLE A DESGRIPTTOH FOR GROUP 5 ?

1 to 24 charaters

CONTROL VARIABLE 4 DESCRIPTION FOR GROUP 6?

1 to 24 charaters

CONTROL VARTABLE 4 DESCRIPTION FOR GROUP $7 ?$

1 to 24 character:

CONTROL VARIABLE L DESGRIPTION FOR GROUP B?

1 to 24 characters

CONTHOL VARIALLE L DESCRIPTION FOR GROUP $9 ?$

1 to 2 亲 chatacters

CONTROL VARTABLE 4 DESCRTPTION FOR GROUP 10 ?

1 to 24 characters

CONTROL VARIABLE 4 DESCRIPTION FOR GKOUP II?

1 to 24 characters

CONTROL VARIABLE 4 DESCRIPTION FOR GROUP 12 ?

1 to 24 characters

CONTROL VARTABLE i DESCRTPTION FOR GROUP 13?

1 to 24 character:

CONTROL VARIABLE A DESCEIPTION VOR GROUP 1

1 to 2 年 charaters

CONTROL YARTABLE 4 DESCRIPTION FOR GROUP IS?

1 to 2 年 chatacter

F OF CONTROL VARIABLE 5 CUTPOINTS?

an integer between 1 \& 14 inclusive

01

CONTROL VARIABLE 5 CUTPOINT(S)?

ascending integer values separated by commas 9999

CONTROL VARIABLE S DESCRIPTION FOR GROUP 1 ? 1 to 24 cistacters 
CONTROL VARIABLE 5 DESCRIPTION FOR GROUP 2 ?

1 to 24 characters

CONTROL VARIABLE 5 DESCRIPTION FOR GROUP 3 ?

1 to 24 characters

CONTROL VARIABLE 5 DESCRIPTION FOR GROUP 4 ?

1 to 24 characters

CONTROL VARIABLE 5 DESCRIPTION FOR GROUP 5 ?

1 to 24 characters

CONTROL VARIABLE 5 DESCRIPTION FOR GROUP 6?

1 to 24 characters

CONTROJ VARIABLE 5 DESCRIPTION FOR GROUP 7 ?

1 to 24 characters

CONTROL VARIABLE 5 DESCRIPTION FOR GROUP 8?

1 to 24 characters

CONTROL VARIABLE 5 DESCRIPTION FOR GROUP 9?

1 to 24 characters

CONTROL VARIABLE 5 DESCRIPTION FOR GROUP 10 ?

1 to 24 characters

CONTROL VARIABLE 5 DESCRIPTION FOR GROUP 11 ?

1 to 24 characters

CONTROL VARIABLE 5 DESCRIPTION FOR GROUP 12 ?

1 to 24 characters

CONTROL VARIABLE 5 DESCRIPTION FOR GROUP 13 ?

1 to 24 characters

CONTROL VARIABLE 5 DESCRIPTION FOR GROUP 14 ?

1 to 24 characters

CONTROL VARIABLE 5 DESCRIPTION FOR GROUP 15 ?

1 to 24 characters 


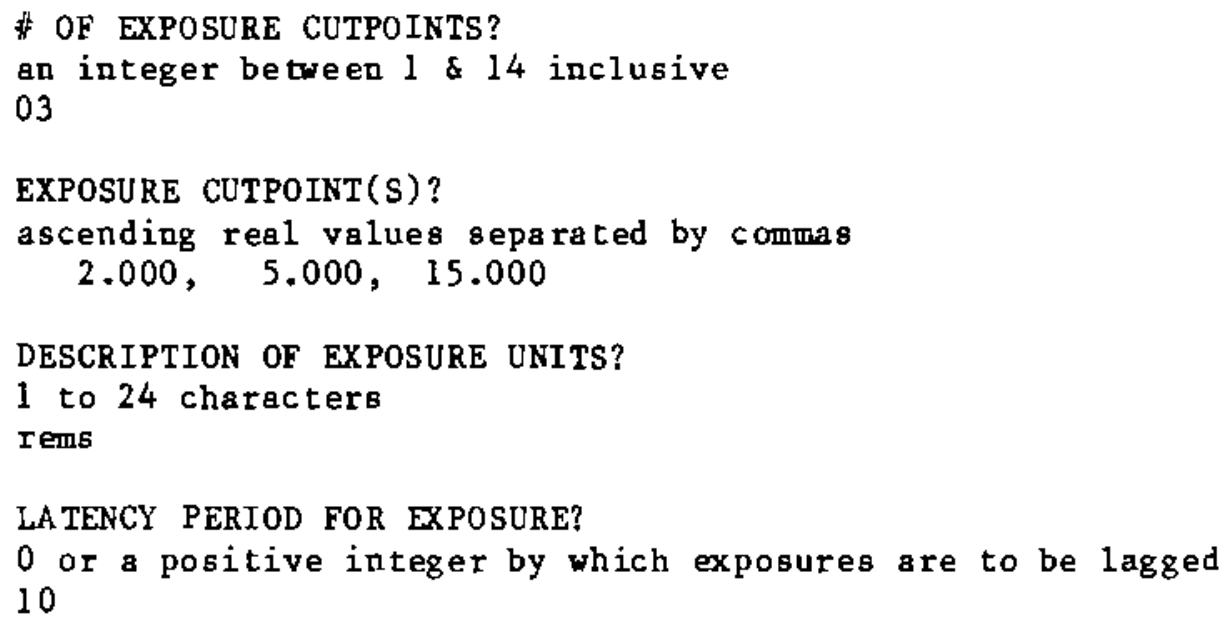


WOWER, UPPER RAWEE OF CODES UN DEATH TABLE 2 ?

non-debcendind integers between 1 \& 999 inclusive separated by comas 9999,9999

DEATH FABLLATYON DESCRIPTION FOR TABLE 2 ?

1 to 80 characters

* OF ICD CODE RANGES IN DEATH TABLE 3?

an integer betwen 1 \& 15 incluaive

01

LOWER, UPPER RANGE OF CODES IN DEATH TABLE 3?

non-debcending integers between 1 \& 999 inclusive separated by commo 9999,9999

DEATH TABULATION DESERTETION FOR TABLE 3 ?

1 to 80 characters

PRINT DOWE TOTAL.

Yes OR no

yes

PAINT UNGROUPED EXPOSUEE ANALYSTS RESULTS?

yes OR no

yes

PRINT GROURED EXPOSURE ANALYSIS RESULTS?

$y \in S$ OR no

yes

ASSIGI SCORES TO THE EXPOSURE CATEGORIES?

yes OR no

no

EXPOSURE CATWOOR SCORES?

(4 of exposure cutpoint +1 ) real values aeparated by tommas
$9,999000 \mathrm{E}+03$
3. $499000 \mathrm{E}+03$,
$9.999000 \mathrm{E}+03$
$9.99000 \mathrm{E}+03$ 
This command file could easily be modified to perform a variety of batch analyses. A $f$ ew examples of changes that could be made are (altered records are indicated by an $*$ ):

EXl. Specify single-year intervals for the secondary control variable.

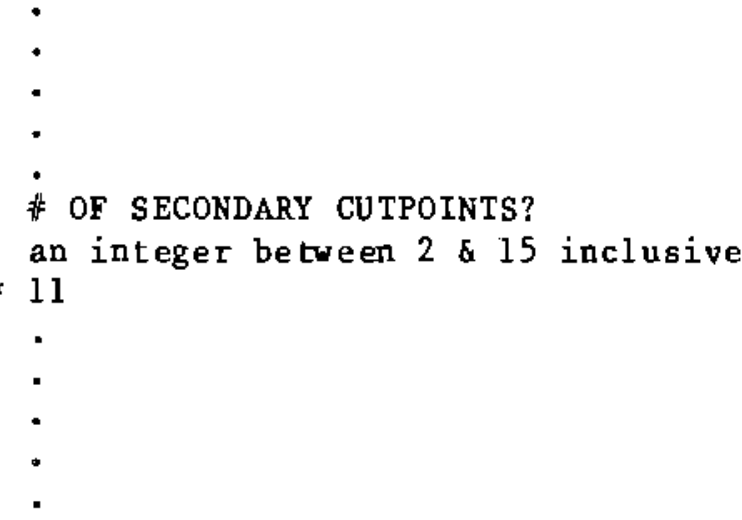

Ex2. Stratify by length of employment. Divide workers into two categories: employed less than 10 years and employed 10 or more years.

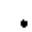

$$
\cdot
$$$$
\cdot
$$
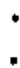
EX3. Stratify by job category. Divide workers into two categories: non-nuclear (job codes of $1 \& 4$ ) and nuclear (codes of $2 \& 3$ ).

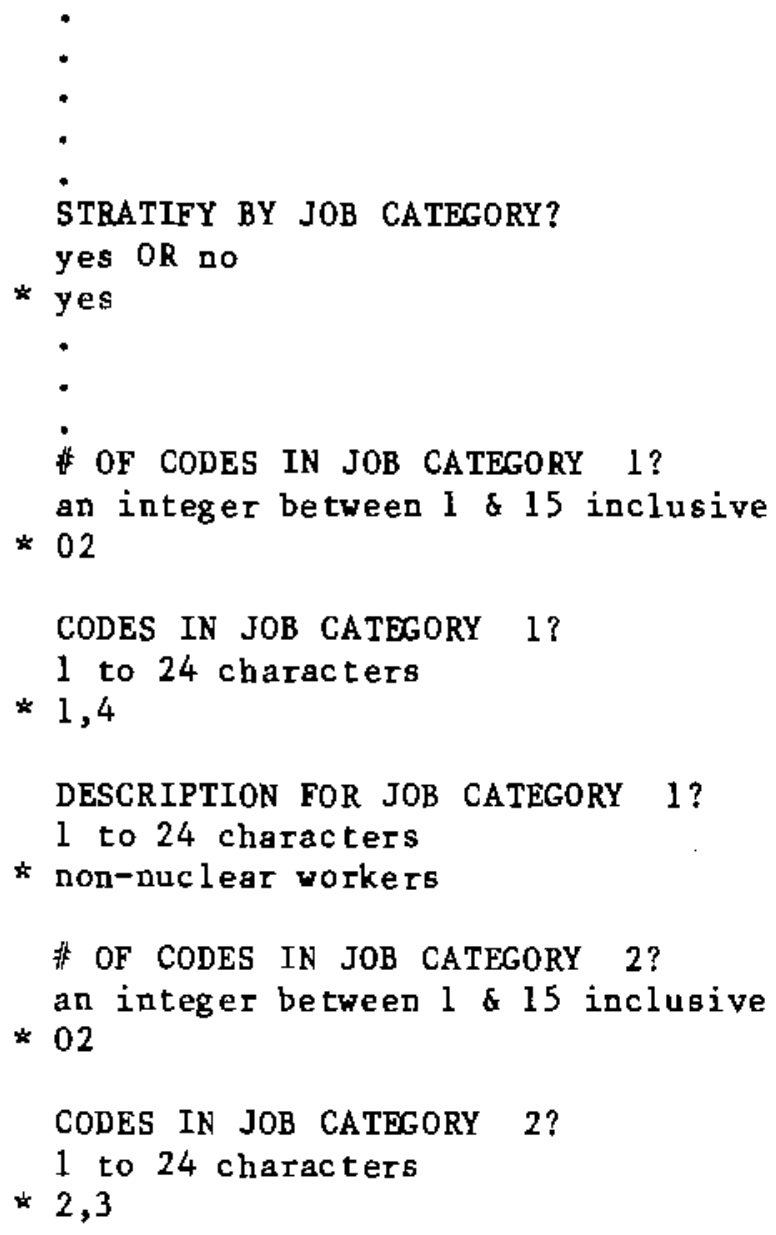


Keep the following thoughts in mind when modifying a Mox command file:

1. Never add or delete a record (except a multiple record list of cutpoints or ICD codes). This includes all blank records.

2. As in our examples, responseg are normally the only records changed. However, prompts may be reworded if so desired.

3. To nullify the action a positive response invokes, change only that response. For instance, in example 3 ve chose to stratify by job category. In a subsequent analysis (using this command file) we might decide not to control for job category. To nullify the control, all we have to do is change the first response in the example. Thus, once the particulars for each control variable are specified, they can simply be turned off and on to perform different analyses.

4. Follow the help or rule preceding each response you change. The responses are screened for gross errors, but a strange analysis could occur if the rules are violated.

You may feel more comfortable having MoX interactively prompt you for the specifications necessary to perform each analysis. In this mode, an incorrect response vill not be accepted and you can take immediate sction. You also have the option of performing an interactive analysis. The principal disadvantage of operating in this mode is that you must re-enter all of your specifications each time you perform an analysis. 
This output* was created by submitting the command file in Appendix $G$ as a batch job. The command used was:

submit sample

(The name of this file is SAMPLE. RPT)

MOX STARTED AT 12:01:04 ON 4-NOV-83

REPORT FILE NAME: sample.rpt

TASK NAME: white males start year=max ( 1 reading + latent +1 , $\$ 3$ reading +1 )

STARTING YEAR OF STUDY: 1944

ENDING YEAR OF STUDY: 1978

BINARY INPUT FILE: no

INPUT FILE NAME: sample.dat

CREATING A SUBFILE: yes

SUBFILE NAME: sample.sub

PRIMARY CONTROL VARIABLE: age

\# OF PRIMARY CUTPOINTS: 48

EQUAL PRIMARY CUTPOINT INTERVALS: no

$\begin{array}{llllllllll}\text { PRIMARY CUTPOINTS: } & 25 & 30 & 35 & 36 & 37 & 38 & 39 & 40 & 41 \\ & 42 & 43 & 44 & 45 & 46 & 47 & 48 & 49 & 50 \\ & 51 & 52 & 53 & 54 & 55 & 56 & 57 & 58 & 59 \\ & 60 & 61 & 62 & 63 & 64 & 65 & 66 & 67 & 68 \\ & 69 & 70 & 71 & 72 & 73 & 74 & 75 & 76 & 77 \\ & 78 & 79 & 80 & & & & & & \end{array}$

* The tables in this appendix have calendar year grouped into four categories $(-1959,1960-64,1965-69,1970-)$ to limit the width of the output for this manual. The death analyses results preaented, however, are actually based on calendar year being grouped into eleven categories ( $-1944,1945-49,1950-54$, $1955-59,1960-64,1965-69,1970-74,1975-75,1976-76,1977-77,1978-$ ). 
SECONDARY CONTROL VARIABLE: calendar year

\# OF SECONDARY CUTPOINTS: 03

EQUAL SECONDARY CUTPOINT INTERVALS: yes

FIRST SECONDARY CUTPOINT,LAST SECONDARY CUTPOINT: 19601970

STRATIFY BY LENGTH OF EMPLOYMENT: DO

STRATIFY BY FOLLOW-UP SINCE YEAR OF EMPLOYMENT: no

STRATIFY BY JOB CATEGORY: nO

STRATIFY BY USER-DEFINED CONTROL VARIABLE(S): no

\# OF EXPOSURE CUTPOINTS: 03

EXPOSURE CUTPOINT(S): $\quad 2.000 \quad 5.000 \quad 15.000$

DESCRIPTION OF EXPOSURE UNITS: rems

LATENCY PERIOD FOR EXPOSURE: 10

PRINT TABLES BY PRIMARY \& SECONDARY CATEGORIES ONLY: no

PRINT TABLES OF DEATHS FROM ALL CAUSES: yes

PRINT TABLES OF DEATHS FROM ALL MALIGNANT NEOPLASMS: yes

PRINT TABLES FOR OTHER SPECIFIED CAUSES OF DEATH: yes

\# OF OTHER DEATH TABLES: 01

\# OF ICD CODE RANGES IN DEATH TABLE 1: 01

LOWER, UPPER RANGE OF CODES IN DEATH TABLE 1 : 162162

DEATH TABUIATION DESCRIPTION FOR TABLE 1: lung cancer (162)

PRINT POWER TOTALS: yes

PRINT UNGROUPED EXPOSURE ANALYSIS RESULTS: yes

PRINT GROUPED EXPOSURE ANALYSIS RESULTS: yes

ASSIGN SCORES TO THE EXPOSURE CATEGORIES: no

SPACE AVAILABLE IS 500000 WORDS

11225 WORDS REQUIRED FOR THIS RUN

ELAPSED TIME IS 5.50 BEGIN PROCESSING WORKERS

ELAPSED TIME IS 1215.94 END PROCESSING WORKERS

RECORDS FOR 44502 WORKERS WERE READ

13462 WORKERS WERE PROCESSED 
age

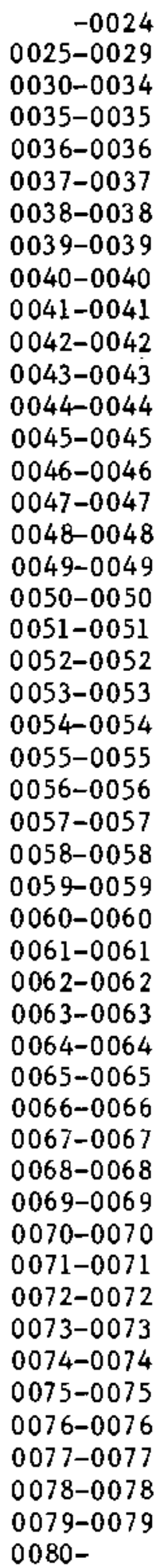

calendar year

\begin{tabular}{|c|c|c|c|c|}
\hline-1959 & $1960-1964$ & $1965-1969$ & $1970-$ & TOTAL \\
\hline 0 & 0 & 0 & 0 & 0 \\
\hline 66 & 92 & 130 & 66 & 354 \\
\hline 1146 & 2636 & 1856 & 2904 & 8542 \\
\hline 484 & 1048 & 927 & 1238 & 3697 \\
\hline 594 & 1156 & 1157 & 1412 & 4319 \\
\hline 645 & 1309 & 1347 & 1602 & 4903 \\
\hline 732 & 1339 & 1492 & 1774 & 5337 \\
\hline 796 & 1383 & 1593 & 1893 & 5665 \\
\hline 853 & 1406 & 1658 & 2068 & 5985 \\
\hline 850 & 1433 & 1684 & 2257 & 6224 \\
\hline 852 & 1428 & 1752 & 2400 & 6432 \\
\hline 854 & 1407 & 1776 & 2579 & 6616 \\
\hline 874 & 1419 & 1769 & 2764 & 6826 \\
\hline 861 & 1447 & 1730 & 2971 & 7009 \\
\hline 796 & 1403 & 1744 & 3146 & 7089 \\
\hline 720 & 1399 & 1713 & 3216 & 7048 \\
\hline 671 & 1345 & 1663 & 3308 & 6987 \\
\hline 629 & 1294 & 1651 & 3311 & 6885 \\
\hline 584 & 1237 & 1635 & 3286 & 6742 \\
\hline 546 & 1143 & 1589 & 3317 & 6595 \\
\hline 476 & 1057 & 1561 & 3277 & 6371 \\
\hline 445 & 973 & 1492 & 3237 & 6147 \\
\hline 402 & 887 & 1445 & 3159 & 5893 \\
\hline 334 & 835 & 1370 & 3097 & 5636 \\
\hline 299 & 775 & 1271 & 3022 & 5367 \\
\hline 292 & 685 & 1173 & 2905 & 5055 \\
\hline 307 & 613 & 1074 & 2817 & 4811 \\
\hline 308 & 557 & 976 & 2719 & 4560 \\
\hline 297 & 485 & 916 & 2551 & 4249 \\
\hline 274 & 452 & 844 & 2410 & 3980 \\
\hline 249 & 428 & 748 & 2258 & 3683 \\
\hline 223 & 432 & 664 & 2106 & 3425 \\
\hline 186 & 408 & 597 & 1950 & 3141 \\
\hline 172 & 385 & 524 & 1777 & 2858 \\
\hline 138 & 353 & 477 & 1600 & 2568 \\
\hline 122 & 319 & 443 & 1448 & 2332 \\
\hline 122 & 278 & 422 & 1258 & 2080 \\
\hline 113 & 237 & 379 & 1134 & 1863 \\
\hline 95 & 200 & 354 & 995 & 1644 \\
\hline 91 & 166 & 309 & 870 & 1436 \\
\hline 67 & 136 & 284 & 766 & 1253 \\
\hline 63 & 121 & 236 & 666 & 1086 \\
\hline 41 & 114 & 187 & 589 & 931 \\
\hline 32 & 88 & 145 & 523 & 788 \\
\hline 17 & 83 & 110 & 463 & 673 \\
\hline 9 & 57 & 99 & 399 & 564 \\
\hline 4 & 48 & 81 & 334 & 467 \\
\hline 0 & 30 & 78 & 273 & 381 \\
\hline 0 & 43 & 215 & 999 & 1257 \\
\hline 18731 & 36569 & 47340 & 95114 & 197754 \\
\hline
\end{tabular}




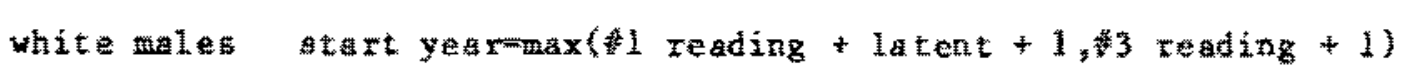

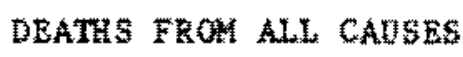

age

calendar yeat

-1959 1960-1964 1965-1969 1970- TOTAL

$-0024$

$0025-0029$

0030-0034

0035-0035

$0036-0036$

$0037-0037$

$0038-003$

$0039-0039$

$0040-0000$

$0041-0041$

$0042-00=2$

$0043-0043$

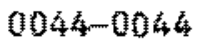

$0045-0045$

$0046-0046$

$0047-004 ?$

$0048-0048$

$0049 \cdots 0049$

$0050=0050$

$0051-0051$

$0052-0052$

$0053-0053$

$0054=0054$

$0055-0055$

$0056-0056$

$0057-0057$

$0058-0058$

$0059-0059$

$0060-0060$

$0061-0061$

$0062-0062$

$0063-0063$

$0064-0064$

$0065-0065$

$0066-0065$

$0067-0067$

$0068-0068$

$0069-0069$

$0070 \mathrm{mo0} 70$

$0071-0071$

0072-0072

$0073-0073$

$0074=0074$

$0075-0075$

$0076-0076$

$0077-0077$

$0078-0078$

$0079-0079$

oOBO-

0
0
1
1
1
3
0
2
3
1
1
1
5
7
5
6
5
3
7
2
4
1
2
7
3
2
5
3
6
10
7
7
5
8
2
4
4
4
2
5
5
3
1
1
2
0
0
5

0
0
1
1
1

0

2

0

3

4

5

$$
7
$$

3

5

6

7

5

6

6

等

12

8

7

12

18

15

14

17

10

13

16

15

12

12

15

23

16

1 器

1 橆

20

I6

11

16

18

14

17

$1 \mathfrak{l}$

9

7

6

名

22

310

338

1305

$\begin{array}{ll}0 & 0 \\ 0 & 0 \\ 4 & 8 \\ 1 & 3 \\ 0 & 5\end{array}$

11

130 
white males start yearmax ( $\$ 1$ reading +1 latent +1 , $\# 3$ reading +1$)$

DEATHS FROM ALL CANCERS

age

calendar year
$-1959 \quad 1960-1964 \quad 1965-1969$

$-0024$

0025-0029

0030-0034

0035-0035

0036-0036

0037-0037

0038-0038

0039-0039

0040-0040

0041-0041

0042-0042

0043-0043

0044-0044

0045-0045

0046-0046

0047-0047

0048-0048

0049-0049

0050-0050

$0051-0051$

0052-0052

0053-0053

0054-0054

0055-0055

0056-0056

0057-0057

0058-0058

0059-0059

0060-0060

0061-0061

0062-0062

0063-0063

0064-0064

0065-0065

0066-0066

0067-0067

0068-0068

0069-0069

0070-0070

0071-0071

0072-0072

0073-0073

0074-0074

0075-0075

0076-0076

0077-0077

0078-0078

0079-0079

0080-

\section{-1959 1960-1964 1965-1969}

$1970-$

TOTAL

$\begin{array}{ll}0 & 0 \\ 0 & 0 \\ 0 & 1 \\ 0 & 1 \\ 0 & 0\end{array}$

0

0

0

0

2

0

0

0

0

1

1

3
2

2
0

1

0

1

0

2

0

0

1

1

0

1

0
2

2

2

0

1

2

2

0

1

2

0

1

1

1

0
0

0 


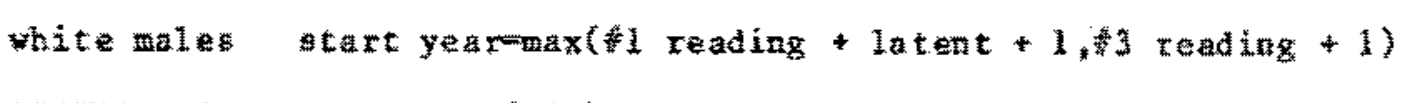

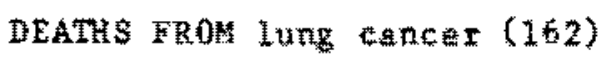

$\operatorname{age}$

calendat year

$-1959 \quad 1960-1964 \quad 1965-1969$

$1970 \mathrm{~m}$

TOTAL

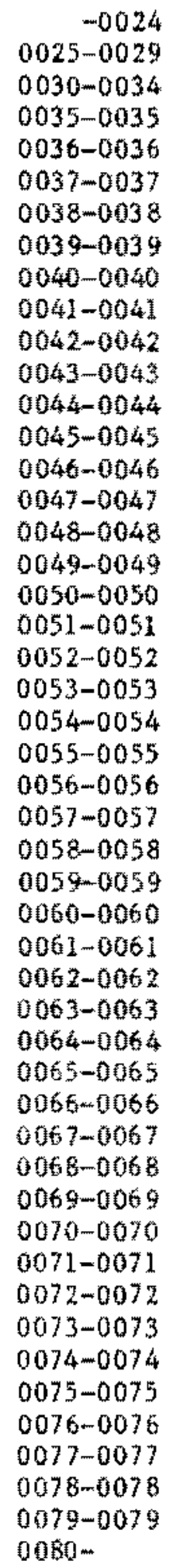

0

0

0

$0 \quad 0$

$0 \quad 0$

0

0

0

1

0

0

0

0

1

0

0

2

1

0

0

0

3

0

1

1

0

3

0

0

0

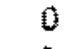

1

1

1

1

0

0

0

0

0

0

0

0

17

31

97 


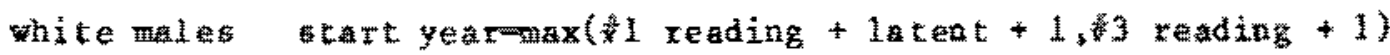

EXTOSURE MEAN

a ge

-0024
$0025-0029$
$0030-0034$
$0035-0035$
$0035-0036$
$0097-0037$
$0038-0038$
$0039-0039$
$0040-0040$
$0041-0041$
$0042-0042$
$0043-0043$
$0044-004$
$0045-0045$
$0046-0046$
$0047-0047$
$0045-0048$
$0045-0049$
$0050-0050$
$0051-0051$
$0052-0052$
$0053-0053$
$0054-0054$
$0055-0055$
$0056-0056$
$0057-0057$
$0058-0058$
$0059-0059$
$0050-0060$
$0061-0061$
$0062-0062$
$0063-0063$
$0064-0054$
$0065-0065$
$0066-0066$
$0067-0067$
$0068-0068$
$0069-0069$
$0070-0070$
$0071-0071$
$0072-0072$
$0073-0073$
$0074-0074$
$0075-0075$
$0076-0076$
$0077-0077$
$0078-0078$
$0079-0079$
$0080-$

calendar year

$-1959 \quad 1960-1964 \quad 1963 m 1969 \quad 1970-\quad$ TOTAL.

$0.0000 \mathrm{E}+00$

$0.0000 E+00$

$0.0000 E+00$

$0.0000 \mathrm{E}+00$

$0.0000 \mathrm{E}+00$

$2.8030 \mathrm{E}-02$

$9.9939 \mathrm{E}-02$

$2.0415 \mathrm{E}-\mathrm{mol}$

$3.0027 \mathrm{E}-01$

3.7874.

$3.8004 \mathrm{E}-01$

$3.6569 \mathrm{~L}-01$

$3.1537 \mathrm{E}-\mathrm{m}$

$3.2067 \mathrm{E}-11$

$3.275 \mathrm{~s}-01$

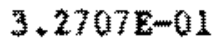

3.2.3001

3.3268 -01

$3.3707 \mathrm{~m}-01$

$3.53245-01$

$3.4283 \mathrm{E}-01$

3. $18305-01$

$3.0757 \mathrm{z}-01$

$2.9896 \mathrm{E}-01$

$3.0113 \mathrm{E}-01$

3. $1380 \mathrm{E}-01$

3.0684E-01

2. $8090 \mathrm{Em}-01$

$2.268 \mathrm{E}-01$

2. $1.664 \mathrm{z}-01$

2. $1570 \mathrm{E}-01$

2. $2136 \mathrm{E}-01$

2.31115 01

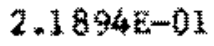

2. 1972 管而田

2.0726

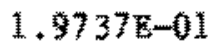

1.8581 $\mathrm{Em}$

$2.2290 \mathrm{~g}$-01

2. $2910 \mathrm{~g}$

$2.1651 \mathrm{E}-01$

2. $1407 \mathrm{E}-01$

2.0263E-m01

$1.870 .3 \mathrm{Em} 01$

2.0284 $\mathrm{E} 01$

$2.2603 \mathrm{E}-01$

$2.307 .3 \mathrm{E}-01$

$3.3406 \mathrm{E}-01$

$4.9235 \mathrm{E}-01$

$6.4778 \mathrm{E}-01$

$3.3750 \mathrm{E}-01$

$0.0000 \mathrm{E}+00$

0. $0000 \mathrm{E}+00$

8.0978E-02

$2.2656 \mathrm{E}-01$

3. $2006 \mathrm{E}-01$

3. 3624E-01

$3.5068 \mathrm{E}-01$

3. $8726 \mathrm{E}-01$

$4.5526 \mathrm{E}-01$

$5.1791 \mathrm{E}-01$

5. $3138 \mathrm{E}-01$

$5.6153 \mathrm{E}-01$

$5.5863 \mathrm{E}-01$

$5.5746 \mathrm{E}-01$

5. $4782 \mathrm{E}-01$

$5.59845-01$

$5.7457 \mathrm{E}-01$

$5.7959 \mathrm{E}-01$

$6.0390 \mathrm{E}-01$

6. $3447 \mathrm{E}-01$

$6.5050 \mathrm{E}-01$

$6.4335 \mathrm{E}-01$

$6.3017 \mathrm{E}-01$

$5.7785 \mathrm{E}-01$

$5.7968 \mathrm{E}-01$

6. 0494E-01

$5.5234 \mathrm{E}-01$

5. $6843 \mathrm{E}-01$

$5.2887 \mathrm{E}-01$

5. $0433 \mathrm{E}-01$

4. $443 \mathrm{E}-01$

4. $423 \mathrm{E}-01$

4.8729E-01

$5.0542 \mathrm{E}-0.1$

稪. $8565 \mathrm{~B}-01$

4, 毒2015-01

$4.1266 \mathrm{E}-01$

$4.20252-01$

3. $8000 \mathrm{E}-01$

$3.9865 \mathrm{E}-01$

4.2681 $\mathrm{E}-01$

4. $5816 \mathrm{E}-01$

4. 3942 $\mathrm{E}-01$

4. $8868 \mathrm{E}-01$

$3.8375 \mathrm{E}-0 \mathrm{l}$

$3.4735 \mathrm{E}-01$

$3.3263 \mathrm{E} \sim 01$

4. 3229E-01

$1.0469 \mathrm{E}-01$

$4.1685 \mathrm{E}-01$

$1.81 .97 \mathrm{E}-01$

6. $912.1 \mathrm{Em} 01$

$7.1876 \mathrm{E}-01$

$8.5815 \mathrm{E}-01$

$9.4845 \mathrm{E}-01$

1. $0065 \mathrm{E}+00$

1. . $726 \mathrm{E}+00$

1. $3880 \mathrm{E}+00$

$1.60025+00$

$1.81 .75 \mathrm{E}+00$

$1.1118 \mathrm{E}$

$1.1568 \mathrm{E}+00$

1. $1931 \mathrm{E}+00$

1. 2337 की

1. $2386 \mathrm{E}+00$

1. $2386 \mathrm{E}+0 \mathrm{O}$

$1.2547 \mathrm{zOO}$

1. $999 \mathrm{E}+40$

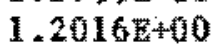

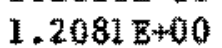

$1,1940 \mathrm{E}+00$

1.1508200

$1,1590 \mathrm{E}+00$

$1.2272 \mathrm{E}+00$

1. $2340 E+00$

1. $2938 \mathrm{E}+00$

1. $3125 \mathrm{E}+00$

1. $3209 \mathrm{E}+00$

$1.31020+00$

$1.3256 \mathrm{E}+00$

1. 1890400

$1.1903+40$

$1.2186 \mathrm{E}+00$

$1.1768 \mathrm{E}+00$

1.1158000

1. $1030 \mathrm{O}+100$

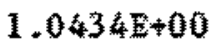

9.

$9.9255 \mathrm{E}-0$.

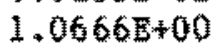

$1.0385 \mathrm{E}+00$

$8.7186 \mathrm{E}-01$

8. $1861 \mathrm{E}-01$

7. $5504 \mathrm{E}-01$

$8.3631 \mathrm{E}=01$

$7.4513 \mathrm{E}-01$

$7.7834 \mathrm{E}=01$

$6.6873 \mathrm{E}-01$

$6.4960 \mathrm{E}-01$

$5.8284 \mathrm{E}-01$

1.9701 E00

$2.06890+00$

2. 332500

2. $\$ 355+00$

2.46

2.86

2. 7812 等 +00

2.

$2.92 \mathrm{cot}+00$

$3.0356 \mathrm{E}+10$

3.0757500

3.1203 400

$3.1006+00$

$3.0827 \mathrm{E}+00$

$3.0382 \mathrm{E}+00$

2. $9834 \mathrm{E}+00$

$2.9250 \mathrm{E}+00$

$2.9568 \mathrm{BE}+00$

$2.9950 \mathrm{z}+00$

$2.99795+00$

$3.01552+00$

3.0584260

3.

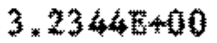

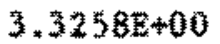

$3.3696+00$

3. 3810 ante

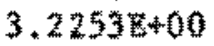

3.1290 策+00

3. $2090+00$

$3.07 \mathrm{E}+00$

$3.2313 \mathrm{E}+00$

$3.0125 \mathrm{E}+00$

$2.6407 \mathrm{E}+00$

$2.5501 \mathrm{E}+00$

$2,2446 \mathrm{E}+00$

1. $9963 \mathrm{E}+00$

$1.7759 \mathrm{E}+010$

3. $8200 \mathrm{E}-01$

$5.7346 \mathrm{E} 01$

$1.70482+00$

$1.4718 \mathrm{E}+00$

1. $1060 \mathrm{E}+00$

$6.0093 \mathrm{E}-01$

$3.8777 \mathrm{~m} .01$

6. $5318 \mathrm{E}-101$

$9.8644 \mathrm{E}-02$

$4.0888 \mathrm{E}-01$

$6.9036 \mathrm{E}-01$

8. $1497 \mathrm{E}-01$

$9.2687 \mathrm{E}-01$

I. $-03482+00$

1. $1335 \mathrm{E}+00$

1. $2020 \mathrm{E}+00$

$1,2975 \mathrm{E}+00$

1. $3823 \mathrm{E}+00$

1. $453 \mathrm{E}+00$

1.55 $11 \mathrm{E}+00$

1.6. $255+00$

1. $7162 \mathrm{~s}+00$

1. $7783 \mathrm{E}+00$

1. $8697 \mathrm{E}+00$

$1.9060 \mathrm{E}+00$

$1.9429 \mathrm{E}+00$

1. $9762 \mathrm{E}+00$

$2.0156 \mathrm{E}+00$

$2.0219 E+00$

$2.0244 \mathrm{E}+00$

$2.0289 \mathrm{E}+00$

$2.0775 \mathrm{E}+00$

2.1139E+00

$2.1375 \mathrm{E}+00$

2.1319E+00

2. $1665 \mathrm{~s}+00$

$2.2382 \mathrm{E}+00$

$2.2879 \mathrm{E}+00$

$2.3363 \mathrm{E}+00$

2.3789800

2. $37025+00$

$2.2657 \mathrm{E}+00$

2. $1992 \mathrm{E}+00$

$2,1122 \mathrm{E}+00$

$2.1462 \mathrm{E}+00$

2. $2036 \mathrm{E}+00$

$2.0625 \mathrm{E}+00$

1. $8460 \mathrm{E}+00$

$1.8077 \mathrm{E}+00$

$1.6397 \mathrm{E}+00$

$1.5246 \mathrm{E}+00$

1. $3864 \mathrm{E}+00$

1. $3640 E+00$

$1.2010 \mathrm{E}+00$

$9.3997 \mathrm{E}-01$

$6.0600 \mathrm{E}-0 \mathrm{z}$

$2.9074 \mathrm{E}-01 \quad 4.9967 \mathrm{E}-01 \quad 1.1188 \mathrm{E}+00 \quad 2.7119 \mathrm{E}+00 \quad 1.6921 \mathrm{E}+00$ 
white males wat yearmax

age

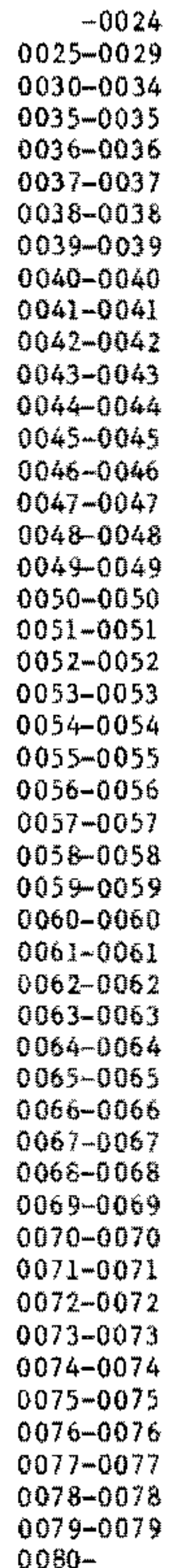

calendar yeat

$$
-1959 \quad 1960-1964 \quad 1965-1969 \quad 1970
$$

$0.0000 \mathrm{E}+00$

$3.2613 \mathrm{E}-03$

4. $1805 \mathrm{E}-02$

$1.6728 \mathrm{~mol}$

$3.2966 \mathrm{w}=1$

$4.2755 \mathrm{E}-01$

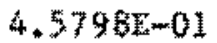

4. $1030 \mathrm{O}$

2. 8 整5 5 - 01

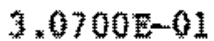

3.0150501

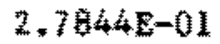

2. 8 (4) 22E-61

2. ${ }^{2}$ a $95 \mathrm{Em} 01$

2.8001 E-OL

2.9711.

$2.6811 \mathrm{Em}$

2. $448 \mathrm{E}-01$

2. $3588 \mathrm{E}-\mathrm{O} 1$

$2.0466 \mathrm{E}-01$

$2.1492 \mathrm{E}-\mathrm{O} 1$

$2.4065 \mathrm{E}-01$

2. $2596 \mathrm{E}-01$

$2.0934 \mathrm{E}-01$

1. $3133 \mathrm{E}-01$

$1.1971 \mathrm{E}=01$

$1 * 2195-01$

$1.6165 \mathrm{E}-\mathrm{b} 1$

1. $631 \mathrm{Em} 01$

1. $233 \mathrm{EE}$

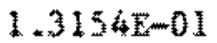

1. 2 a $70 \mathrm{E}-01$

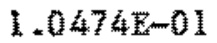

1.4231501

1. $4.315 \mathrm{y}-01$

1. $2850-51$

1. $16192-01$

1. $2484 \mathrm{E}$ mal

1.7050E-01

1. $\$ 142 \mathrm{Em} 01$

$1.8590 \mathrm{E}-01$

$2.5228 \mathrm{E}-01$

$1.6942 \mathrm{E}-01$

$2.3682 \mathrm{E}-01$

$4.1071 \mathrm{E}-01$

$6.4131 \mathrm{E}-0 !$

1. $12425=01$

$0.00005+00$

$0.0000 \mathrm{E}+00$
$0.0000 \mathrm{E}+00$

$3.6322 \mathrm{E}-02$

$1.5133 \mathrm{E}-01$

$2.6822 \mathrm{E}-01$

$2.9878 \mathrm{E}-01$

$3.1708 \mathrm{E}-01$

$3.6087 \mathrm{E}-01$

4. $8041 \mathrm{E}-01$

$6.2601 \mathrm{E}-01$

$6.1114 \mathrm{E}-01$

$6.6570 \mathrm{E}-01$

$6.0741 \mathrm{E}-01$

$6.1421 \mathrm{E}-01$

$5.8259 \mathrm{E}-01$

$5.5212 \mathrm{E}-01$

$6,1713 \mathrm{E}-01$

$5.8264 \mathrm{E}-01$

$6.1167 \mathrm{E}-01$

$7.1600 \mathrm{E}-01$

$8.3740 \mathrm{E}-01$

$8.0135 \mathrm{E}-01$

$7.6779 \mathrm{E}-01$

$5.3871 \mathrm{E}-01$

$5.6263 \mathrm{E}-01$

$6.7968 \mathrm{E}-01$

$5.6602 \mathrm{E}-01$

$6.5640 \mathrm{E}-01$

$5.5352 \mathrm{E}-01$

$5.4590 \mathrm{E}-01$

$3.5769 \mathrm{E}-01$

$3.6191 \mathrm{E}-01$

$4.6343 \mathrm{E}-01$

$5.6687 \mathrm{E}-01$

$5.3654 E-01$

$4.6772 \mathrm{E}-01$

$3.1026 \mathrm{E}-01$

$4.1718 \mathrm{E}-01$

$2.5522 \mathrm{E}-01$

$2.4563 \mathrm{E}-01$

$2.9185 \mathrm{E}-01$

$4.1503 \mathrm{E}-01$

$5.2528 \mathrm{E}-01$

$8.5030 \mathrm{E}-01$

$3.4308 \mathrm{E}-01$

$3.5499 \mathrm{E}-01$

$3.1267 \mathrm{E}-01$

$5.8256 \mathrm{E}-01$

$6.3350 \mathrm{E}-01$

$1.5022 \mathrm{E}+00$
$0.0000 \mathrm{E}+00$

$3.2894 \mathrm{E}-02$

$5.3235 \mathrm{E}-01$

$1.3093 \mathrm{E}+00$

$1.6610 \mathrm{E}+00$

$1.9473 \mathrm{E}+00$

$2.3626 \mathrm{E}+00$

$3.0663 \mathrm{E}+00$

$3.5032 \mathrm{E}+00$

$3.9099 \mathrm{E}+00$

$4.3264 \mathrm{E} 400$

$4.4958 \mathrm{E}+00$

$4.1933 E+00$

$3.9994 \mathrm{E}+00$

$3.6943 \mathrm{E}+00$

$3.6675 \mathrm{E}+00$

$3.7097 \mathrm{E}+00$

$3.7281 \mathrm{E}+00$

$3.2548 \mathrm{E}+00$

$3.2416 \mathrm{E}+00$

$3.7177 \mathrm{E}+00$

$3.5132 \mathrm{E}+00$

$4.0803 \mathrm{E}+00$

$4.6281 \mathrm{E}+00$

$5.0374 \mathrm{E}+00$

$4.8088 \mathrm{E}+00$

$5.2696 \mathrm{E}+00$

$3.5052 \mathrm{E}+00$

$3.3951 \mathrm{E}+00$

$3.6630 \mathrm{E}+00$

$3.5616 \mathrm{~B}+00$

$3.5901 \mathrm{~B}+00$

$3.8302 \mathrm{E} \div 00$

$3.4158 \mathrm{E}+00$

$3.1744 \mathrm{E}+00$

$3.4413 \mathrm{E}+00$

$4.3574 \mathrm{E}+00$

$4.1960 \mathrm{E}+00$

$2.7214 \mathrm{E}+00$

$2.1922 \mathrm{E}+00$

$1.6031 \mathrm{E}+00$

$2.3400 \mathrm{E}+00$

$1.7157 \mathrm{E}+00$

I. $5884 \mathrm{E}+00$

$1.1876 \mathrm{E}+00$

$1.2887 \mathrm{E}+00$

$1.3068 \mathrm{E}+00$

$1.4212 \mathrm{E}+00$

$6.7622 \mathrm{E}-01$
$0.0000 \mathrm{E}+00$

$1.5538 \mathrm{E}-01$

$1.4320 \mathrm{E}+00$

$3.2005 \mathrm{E}+00$

$4.5364 \mathrm{E}+00$

$\$ .6971 \mathrm{E}+00$

$7.4639 \mathrm{E}+00$

$9.2005 E+00$

$1.0810 \mathrm{E}+01$

$1.27418+01$

$1.4819 \mathrm{E}+01$

$1.6860 \mathrm{E}+01$

$2.0292 \mathrm{E}+01$

$2,2563 \mathrm{E}+01$

$2.4377 \mathrm{E}+01$

$2.5660 \mathrm{E} 401$

$2.8313 \mathrm{E}+01$

$2.9033 \mathrm{E}+01$

$3.1456 \mathrm{E} * 01$

$3.1680 \mathrm{E}+01$

$3.2608 \mathrm{E}+01$

$3.1654 \mathrm{E}+01$

$3.0128 \mathrm{E}+01$

$2.9096 \mathrm{E}+01$

$2.8741 \mathrm{E}+01$

$3.0246 \mathrm{E}+01$

$3.0460 \mathrm{E}+01$

$2.9606 \mathrm{E}+01$

$3.0571 \mathrm{E}+01$

$3.3674 \mathrm{E}+01$

$3.4422 \mathrm{E}+01$

$3.6564 \mathrm{E}+01$

$3.8696 \mathrm{E}+01$

$4.0105 \mathrm{E}+01$

$3.6421 \mathrm{E}+01$

$3.5156 \mathrm{E}+01$

$3.3080 \mathrm{E}+01$

$3.4044 \mathrm{E}+01$

$3.8467 \mathrm{E}+0 \mathrm{l}$

$3.581 .3 \mathrm{E}+0 \mathrm{I}$

$2.9739 E+01$

$2.9052 \mathrm{E}+01$

$2.1544 \mathrm{E}+01$

$1.9692 \mathrm{E}+01$

$1.5645 \mathrm{E}+01$

$1.5333 \mathrm{E}+01$

$1.2431 \mathrm{E}+01$

$6.5211 \mathrm{E}+00$

$1.8405 \mathrm{E}+00$ 


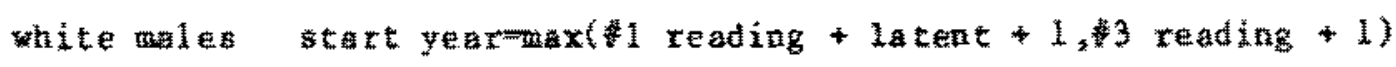
DERSON-YEARS WN EXPOSURE CATECORY $1 \quad \times 2.0$ IEM

\begin{tabular}{|c|c|c|c|c|c|}
\hline age & \multicolumn{4}{|c|}{ calendar year } & TOTAL. \\
\hline-0024 & 0 & 0 & 0 & 0 & 0 \\
\hline $0025-0029$ & 66 & 92 & 130 & 65 & 353 \\
\hline $0030-0034$ & 1145 & 2611 & 1769 & 2616 & 8141 \\
\hline $0035-0035$ & 479 & 1028 & 841 & 1018 & 3366 \\
\hline $0036-0036$ & 580 & 1130 & 1020 & 1115 & 3845 \\
\hline $0037-0037$ & 621 & 1284 & 1159 & 1227 & 4291 \\
\hline $0038-0038$ & 703 & 1304 & 1274 & 1.302 & 4583 \\
\hline $0039-0039$ & 768 & 1320 & 1335 & 1372 & 4795 \\
\hline $0040-0040$ & 834 & 1325 & 1385 & 1497 & 5041 \\
\hline $0041-0041$ & 834 & 1347 & 1409 & 1642 & 5202 \\
\hline $0042-0042$ & 837 & 1341 & 146 & 169 & 5332 \\
\hline $0043-0043$ & 836 & 1330 & 1486 & 1601 & 5453 \\
\hline $0042-0044$ & 854 & 1344 & 1470 & 1905 & 5573 \\
\hline $0045-0045$ & 847 & 1375 & 1416 & 2048 & 5688 \\
\hline $0046-0046$ & 777 & 1330 & 1454 & 2138 & 5699 \\
\hline $0047-0047$ & 701 & 1324 & 1417 & 2192 & 5634 \\
\hline $0048-0048$ & 661 & 1267 & 1384 & 2252 & 5564 \\
\hline $0049-0049$ & 619 & 1220 & 1387 & 2243 & 5469 \\
\hline $0050-0050$ & 575 & 1156 & 1381 & 2246 & 5358 \\
\hline $0051-0051$ & 539 & 1063 & 1343 & 2283 & 5228 \\
\hline $0052-0052$ & 470 & 990 & 1300 & 2268 & 5028 \\
\hline $0053-0053$ & 435 & 913 & 1251 & 2253 & 4852 \\
\hline $0054-0054$ & 395 & 839 & 1188 & 2207 & 4629 \\
\hline $0055-0055$ & 329 & 784 & 1130 & 2189 & 4432 \\
\hline $0056-0056$ & 298 & 725 & 1056 & 2119 & 4198 \\
\hline $0057-0057$ & 291 & 652 & 969 & 2031 & 3943 \\
\hline $0058-0058$ & 305 & 580 & 897 & 1973 & 3755 \\
\hline 00590059 & 306 & 534 & 821 & 1903 & 3564 \\
\hline $0060-0060$ & 294 & 467 & 762 & 1797 & 3320 \\
\hline $0061-0061$ & 271 & 440 & 704 & 1690 & 3105 \\
\hline $0062-0062$ & 247 & 415 & 636 & 1569 & 2867 \\
\hline $0063-0063$ & 232 & 417 & 57 & 1654 & 2670 \\
\hline $0064-0064$ & 185 & 389 & 52 告 & 13 & 2440 \\
\hline $0065-006$ & 170 & 371 & 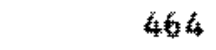 & 1.231 & 2236 \\
\hline $0066-0066$ & 136 & 344 & 432 & 1109 & 2021 \\
\hline $0067-0067$ & 121 & 310 & 401 & 1025 & 1857 \\
\hline $0068-0068$ & 22 & 269 & 376 & 893 & 1660 \\
\hline $0069-0069$ & 113 & 233 & 340 & 796 & 1482 \\
\hline $0070=0070$ & 94 & 196 & 323 & 702 & 1314 \\
\hline $0071-0071$ & 90 & 162 & 285 & 628 & 1165 \\
\hline $0072-0072$ & 66 & 131 & 26.3 & 578 & 1038 \\
\hline $0073-0073$ & 61 & 118 & 214 & 507 & 900 \\
\hline $0074-0074$ & 40 & 108 & 173 & 484 & 785 \\
\hline $0075-0075$ & 31 & 85 & 132 & 429 & 677 \\
\hline $0076-0076$ & 16 & 80 & 103 & 391 & 590 \\
\hline $0077-0077$ & 8 & 55 & 91 & 339 & 493 \\
\hline $0078-0078$ & 4 & 45 & 76 & 292 & 417 \\
\hline $0079-0079$ & 0 & 29 & 73 & 245 & 348 \\
\hline $0080-$ & 0 & 40 & 206 & 949 & 1195 \\
\hline & 18396 & 34912 & 40290 & 67998 & 161596 \\
\hline
\end{tabular}




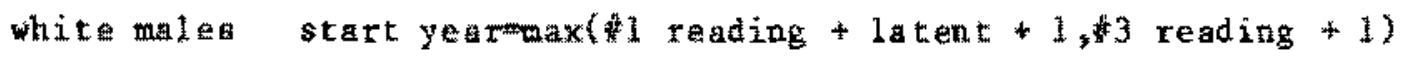

DEATES FWOM ALL GAUSES IN EXPOSURE CATERORY I

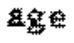

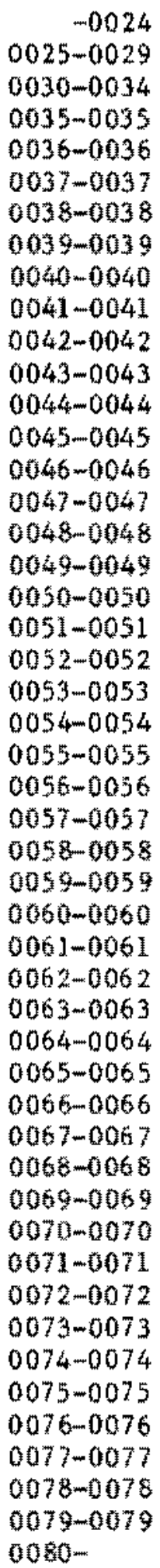

calendar year

$-1959 \quad 1960-1964 \quad 1965-1960$

1970

AT)

(1)

$$
0
$$

0

1

1

$$
2
$$$$
4
$$

1

4

\section{4}

4

4
6

\section{5}

10

11

\section{9}

\section{7}

5

5

9

11

17

10

\section{8}

5

t

10

13

7

8

9

17

13

11

10

9

10

\section{5}

\section{8}

4
5

$$
6
$$$$
6
$$$$
4
$$$$
0
$$

6

325

0
0
1
0
3
3
4
3
5
3
4
6
7
3
6
6
3
12
7
7
11
4

13

13

13

16

7

9

13

9

12

11

13

20

15

18

14

19

15

11

14

17

12

17

10

9

7

6

7

20

454

986
0

6

3

10

12

7

13

11

13

13

22

19

33

31

26

35

34

30

40

42

42

56

47

29

46

51

50

74

58

64

67

64

64

66

67

58

55

60

51

48

48

50

58

34

37

24

149

1922 
white males stat yearmaxt 1 reading + latent +1 ,

DEATHS FROM ALL CANCERS IN EXPOSURE CATECORY 1

age

$$
\text { calendar year }
$$

$$
-1959 \quad 1960-1964 \quad 1965-1969 \quad 1970-
$$

TOTAL

\begin{tabular}{|c|c|}
\hline 0 & 0 \\
\hline 0 & 0 \\
\hline 0 & 1 \\
\hline 0 & 1 \\
\hline 0 & 0 \\
\hline 0 & 1 \\
\hline 0 & 0 \\
\hline 0 & 0 \\
\hline 2 & $\mathfrak{1}$ \\
\hline 0 & 1 \\
\hline 0 & 0 \\
\hline f & 2 \\
\hline 0 & 0 \\
\hline 2 & $\hat{z}$ \\
\hline 1 & 3 \\
\hline 3 & 2 \\
\hline 2 & 1 \\
\hline 0 & 2 \\
\hline 1 & 1 \\
\hline 0 & 2 \\
\hline I & 0 \\
\hline 0 & 0 \\
\hline 1 & 1 \\
\hline 2 & 5 \\
\hline 0 & 3 \\
\hline 0 & 1 \\
\hline 1 & 2 \\
\hline I & 2 \\
\hline 0 & 1 \\
\hline 1 & 3 \\
\hline 0 & 3 \\
\hline 2 & 2 \\
\hline 2 & 1 \\
\hline$\hat{2}$ & 2 \\
\hline 0 & 4 \\
\hline 1 & 4 \\
\hline 2 & 3 \\
\hline 2 & 4 \\
\hline 0 & 2 \\
\hline 1 & 2 \\
\hline 2 & 1 \\
\hline 0 & 1 \\
\hline 1 & 0 \\
\hline 1 & 0 \\
\hline 1 & 0 \\
\hline 0 & 1 \\
\hline 0 & 1 \\
\hline 0 & 0 \\
\hline 0 & 0 \\
\hline
\end{tabular}

$$
\begin{aligned}
& -0024 \\
& 0025-0029 \\
& 0030-0034 \\
& 0035-0035 \\
& 0036-0036 \\
& 0037-0037 \\
& 0038-0038 \\
& 0039-0039 \\
& 0040-0040 \\
& 0041-0041 \\
& 0042-0042 \\
& 0043-0043 \\
& 0044-0044 \\
& 0045-004 \\
& 0046-0046 \\
& 0047-0047 \\
& 0048-0048 \\
& 0049-0049 \\
& 0050-0050 \\
& 0051-0051 \\
& 0052-0052 \\
& 0053-0053 \\
& 0054-0054 \\
& 0055-0055 \\
& 0056-0056 \\
& 0057-0057 \\
& 0058-0058 \\
& 0059-0059 \\
& 0060-0060 \\
& 0061-0061 \\
& 0062-0062 \\
& 0063-0063 \\
& 0064-0064 \\
& 0065-0065 \\
& 0066-0066 \\
& 0067-0067 \\
& 0068-0068 \\
& 0069-0069 \\
& 0070-0070 \\
& 0071-0071 \\
& 0072-0072 \\
& 0073-0073 \\
& 0074-0074 \\
& 0075-0075 \\
& 0076-0076 \\
& 0077-0077 \\
& 0078-0078 \\
& 0079-0079 \\
& 0080-
\end{aligned}
$$

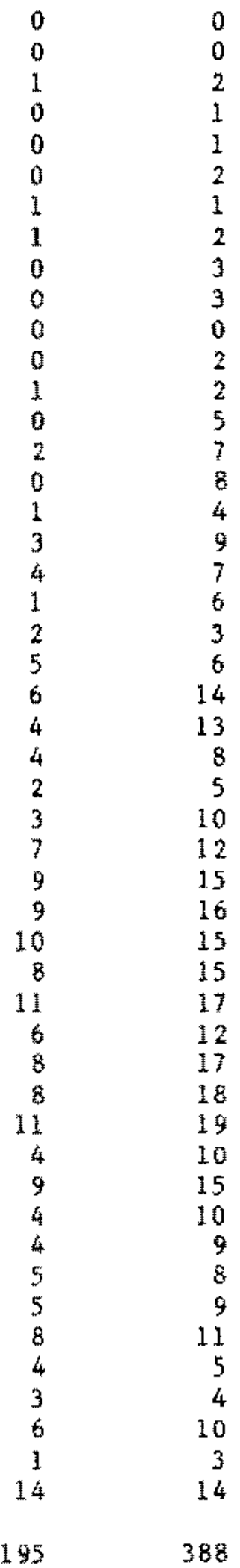


white males start yeamax $(1$ reading +1 atedt $+1,43$ reading + 1$)$

DEATHS FRod lung cancer $(162)$ In EXOSURE CATEGon 1

soge

caleudar yer

$-1959 \quad 1960-1964 \quad 1965-1969 \quad 1970$ ToThL

\begin{tabular}{|c|c|c|c|c|c|}
\hline-0024 & 0 & 0 & 0 & 0 & 0 \\
\hline $0025-0029$ & 0 & 0 & 0 & 0 & 0 \\
\hline $0030-0034$ & 0 & 0 & 0 & 0 & 0 \\
\hline $0035-0035$ & 0 & 0 & 0 & 0 & 0 \\
\hline $0036-0036$ & 0 & 0 & 0 & 0 & 0 \\
\hline $0037-0037$ & 0 & 0 & 1 & 0 & 1 \\
\hline $0036-0038$ & 管 & 0 & 0 & 0 & 0 \\
\hline $0039-0039$ & 0 & 0 & 0 & 0 & 0 \\
\hline $0040-0040$ & 0 & 0 & 0 & 0 & 0 \\
\hline $0041-0041$ & 0 & 0 & 0 & 0 & 0 \\
\hline $0042-0042$ & 0 & 0 & 0 & 0 & 0 \\
\hline $0043-0043$ & 0 & 0 & 0 & 0 & 0 \\
\hline $0044-0044$ & 0 & 0 & 0 & 0 & 0 \\
\hline $0045-0045$ & 0 & 1 & 0 & 0 & 1 \\
\hline $0046-0046$ & 0 & 0 & 1 & 1 & 2 \\
\hline $0047+0047$ & 0 & 0 & 1 & 0 & 1 \\
\hline $0048-6048$ & 1 & 0 & 0 & 0 & 1 \\
\hline $0049-0049$ & 0 & 2 & 0 & 1 & 3 \\
\hline $0050-0050$ & 0 & 0 & 0 & 1 & 1 \\
\hline $0051-0051$ & 0 & 1 & 1 & 0 & 2 \\
\hline $0052-0052$ & 1 & 0 & 0 & 0 & 1 \\
\hline $0053-0053$ & 0 & 0 & 0 & 1 & 1 \\
\hline $0054-0054$ & 1 & 0 & 1 & 4 & 6 \\
\hline $0055-0055$ & 0 & 3 & 0 & 1 & $a$ \\
\hline $0056-0056$ & 0 & 0 & 1 & 0 & 1 \\
\hline $0057-0057$ & 0 & 1 & 1 & 1 & 3 \\
\hline $0058-0058$ & 0 & 1 & 1 & 2 & $t$ \\
\hline $0059-0059$ & 1 & 0 & 0 & 3 & 去 \\
\hline $0060-0060$ & 0 & 0 & 1 & 4 & 5 \\
\hline $0061-0061$ & 1 & 3 & 0 & 亲 & 8 \\
\hline $0062-0062$ & 0 & 0 & 2 & 5 & 7 \\
\hline $0063-0063$ & 0 & 0 & 0 & 2 & 2 \\
\hline $0064-0064$ & 0 & 0 & 2 & 2 & 4 \\
\hline $0065-0065$ & 1 & 0 & 1 & 1 & 3 \\
\hline $0066-0066$ & 0 & 1 & 3 & 3 & 7 \\
\hline $0067-0067$ & 0 & 0 & 2 & 1 & 3 \\
\hline $0065-0068$ & 0 & 1 & 0 & 4 & \\
\hline $0069-0069$ & u & 1 & 0 & 1 & 2 \\
\hline $0070-0070$ & 0 & 1 & 3 & 5 & 9 \\
\hline $007-0071$ & 0 & 0 & 1 & 1 & 2 \\
\hline $0072-0072$ & s. & 0 & 0 & $z$ & \\
\hline $0073-0073$ & 0 & 0 & 2 & 1 & \\
\hline $0074-0074$ & 0 & 0 & 1 & 1 & 2 \\
\hline $0075-0075$ & 0 & 0 & 1 & 2 & \\
\hline $0076-0076$ & 0 & 0 & 0 & 0 & \\
\hline $0077-0077$ & 0 & 0 & 0 & 0 & $\mathrm{c}$ \\
\hline $0078-0078$ & 0 & 0 & 0 & 1 & \\
\hline $0079-0079$ & 0 & 0 & 1 & 1 & $=$ \\
\hline \multirow[t]{2}{*}{$0060-$} & 0 & 0 & 0 & 3 & \\
\hline & 7 & 16 & 28 & 59 & \\
\hline
\end{tabular}


white males start year-max $(\# 1$ reading +1 latent $+1, \$ 3$ reading +1$)$

PERSON-YEARS IN EXPOSURE CATEGORY $2 \quad 2.0$ UP TO 5.0 TEms

age

$$
\begin{aligned}
& -0024 \\
& 0025-0029 \\
& 0030-0034 \\
& 0035-0035 \\
& 0036-0036 \\
& 0037-0037 \\
& 0038-0038 \\
& 0039-0039 \\
& 0040-0040 \\
& 0041-0041 \\
& 0042-0042 \\
& 0043-0043 \\
& 0044-0044 \\
& 0045-0045 \\
& 0046-0046 \\
& 0047-0047 \\
& 0048-0048 \\
& 0049-0049 \\
& 0050-0050 \\
& 0051-0051 \\
& 0052-0052 \\
& 0053-0053 \\
& 0054-0054 \\
& 0055-0055 \\
& 0056-0056 \\
& 0057-0057 \\
& 0058-0058 \\
& 0059-0059 \\
& 0060-0060 \\
& 0061-0061 \\
& 0062-0062 \\
& 0063-0063 \\
& 0064-0064 \\
& 0065-0065 \\
& 0066-0066 \\
& 0067-0067 \\
& 0068-0068 \\
& 0069-0069 \\
& 0070-0070 \\
& 0071-0071 \\
& 0072-0072 \\
& 0073-0073 \\
& 0074-0074 \\
& 0075-0075 \\
& 0076-0076 \\
& 0077-0077 \\
& 0078-0078 \\
& 0079-0079 \\
& 0080-
\end{aligned}
$$

$$
\begin{aligned}
& \text { calendar year } \\
& -1959 \quad 1960-1964 \text {. }
\end{aligned}
$$

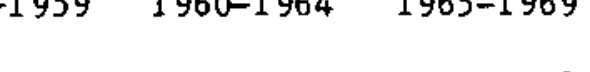

0
0

5

14

24

29

28

19

15

14

18

20

14

19

19

10

10

\section{7}

6
10

10
7

$$
5
$$

\section{1}

1

2

3

3

2

1

(1)

2

1

0

0

1

1

\section{1}

1

1
1
0

0
0
0

$\begin{array}{rr}0 & \\ 0 & \\ 24 & 8 \\ 19 & 74\end{array}$

113

148

172

182

191

179

185

183

206

219

199

208

193

184

181

169

180

157

162

151

129

128

115

109

108

93

73

56

45

37

27

22

24

21

20

15

14

15

9

9

6

7

4

4

9
$1970-$

0
1
231

158

195

223

259

290

306

329

371

410

441

445

495

483

487

486

464

480

477

465

450

435

437

427

402

383

337

324

310

285

267

247

242

209

190

183

156

127

104

87

66

54

36

30

21

16

37

4817

13358
TOTAL

0
1
338
256
346

417

493

561

594

606

652

685

738

745

782

779

766

752

730

732

725

683

666

642

613

586

548

515

463

432

398

356

331

300

278

241

222

208

181

147

123

106

81

67

46

40

28

21

49 


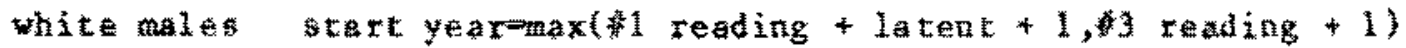

DEATHS FROH ALW CAUSES IN EXPOSURE CATEGORX 2

age

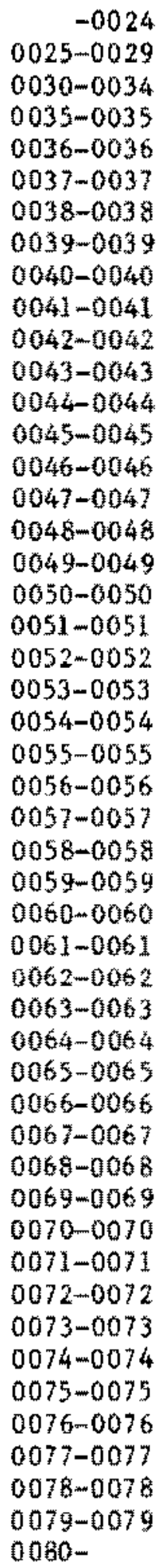

calendar yeat

$$
\begin{array}{lll}
-1959 \quad 1960-1964 \quad 1965-1969
\end{array}
$$

$1970-$

TOTAL

$\begin{array}{ll}0 & 0 \\ 0 & 0 \\ 0 & 0 \\ 0 & 0 \\ 0 & 0\end{array}$

0
0
1
0
0
1
1
0
0
1
0
0
1
0
0
0
1
0
0
0
1
0
0
1
0
1
1
3
2
2
1
1
1
0
1

0

0

0

0

0

0

0

0

0

0

0

0

0

0

0

0

0

0

0

0

0

0

0

0

0

0

0

0

0

0

0

0

0

0

0

0

0

0

0
37

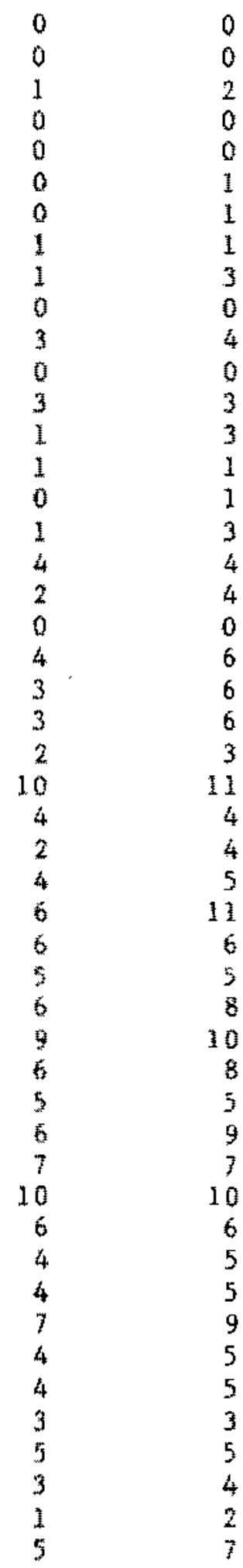


white males start yearmax (非 1 reading + latent +1 , \#3 reading +1 )

DEATHS FROM ALL CANCERS IN EXPOSURE CATEGORY 2

age

calendar year

$0025-0029$

0030-0034

0035-0035

$0036-0036$

$0037-0037$

$0038-0038$

0039-0039

0040-0040

0041-0041

0042-0042

0043-0043

0044-0044

0045-0045

0046-0046

0047-0047

0048-0048

0049-0049

0050-0050

0051-0051

0052-0052

0053-0053

0054-0054

0055-0055

0056-0056

0057-0057

0058-0058

0059-0059

0060-0060

0061-0061

0062-0062

0063-0063

0064-0064

0065-0065

0066-0066

0067-0067

0068-0068

0069-0069

0070-0070

0071-0071

0072-0072

0073-0073

0074-0074

0075-0075

0076-0076

$0077-0077$

0078-0078

0079-0079

0080-

\begin{tabular}{|c|c|c|}
\hline-1959 & $\begin{array}{r}\text { cale } \\
1960-1964\end{array}$ & $\begin{array}{l}\text { ndar year } \\
\qquad 1965-1969\end{array}$ \\
\hline 0 & 0 & 0 \\
\hline 0 & 0 & 0 \\
\hline 0 & 0 & 1 \\
\hline 0 & 0 & 0 \\
\hline 0 & 0 & 0 \\
\hline 0 & 0 & 0 \\
\hline 0 & 0 & 0 \\
\hline 0 & 0 & 0 \\
\hline 0 & 1 & 0 \\
\hline 0 & 0 & 0 \\
\hline 0 & 0 & 0 \\
\hline 0 & 0 & 0 \\
\hline 0 & 0 & 0 \\
\hline 0 & 0 & 1 \\
\hline 0 & 0 & 0 \\
\hline 0 & 0 & 0 \\
\hline 0 & 0 & 0 \\
\hline 0 & 0 & 0 \\
\hline 0 & 0 & 0 \\
\hline 0 & 0 & 0 \\
\hline 0 & 0 & 1 \\
\hline 0 & 0 & 0 \\
\hline 0 & 0 & 0 \\
\hline 0 & 0 & 0 \\
\hline 0 & 0 & 1 \\
\hline 0 & 0 & 0 \\
\hline 0 & 0 & 0 \\
\hline 0 & 0 & 0 \\
\hline 0 & 0 & 1 \\
\hline 0 & 0 & 0 \\
\hline 0 & 0 & 0 \\
\hline 0 & 0 & 0 \\
\hline 0 & 0 & 0 \\
\hline 0 & 0 & 0 \\
\hline 0 & 0 & 0 \\
\hline 0 & 0 & 1 \\
\hline 0 & 0 & 0 \\
\hline 0 & 0 & 0 \\
\hline 0 & 0 & 0 \\
\hline 0 & 0 & 0 \\
\hline 0 & 0 & 0 \\
\hline 0 & 0 & 1 \\
\hline 0 & 0 & 0 \\
\hline 0 & 0 & 0 \\
\hline 0 & 0 & 0 \\
\hline 0 & 0 & 0 \\
\hline 0 & 0 & 0 \\
\hline 0 & 0 & 0 \\
\hline 0 & 0 & 0 \\
\hline 0 & 1 & \\
\hline
\end{tabular}

$1970-$

TOTAL

0

$\begin{array}{ll}0 & 0 \\ 0 & 0\end{array}$

$\begin{array}{ll}0 & 1\end{array}$

$0 \quad 0$

$0 \quad 0$

$0 \quad 0$

$0 \quad 0$

$0 \quad 0$

$\begin{array}{ll}0 & 1\end{array}$

$0 \quad 0$

$0 \quad 0$

$0 \quad 0$

$\begin{array}{ll}1 & 1 \\ 0 & 1\end{array}$

0

$\begin{array}{ll}0 & 0\end{array}$

11

11

11

$\begin{array}{ll}0 & 0\end{array}$




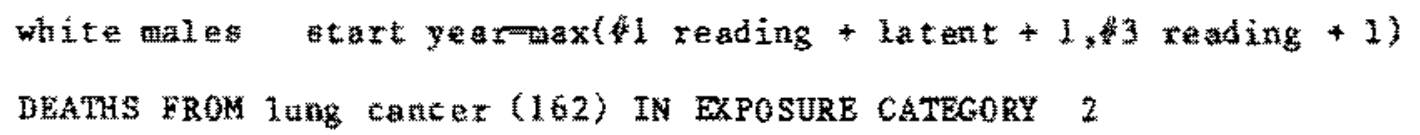

0
0
0
0
0
0
0
0
0
0
0
0
0
0
0
0
0
0
0
0
0
0
0
0
0
0
0
0
0
0
0
0
0
0
0
0
0
0
0
0
0
0
0
0
0
0
0
0
0
0
0
0
0
0
0
0
0

$\begin{array}{lll}0 & 0 \\ 0 & 0\end{array}$

0

$\begin{array}{ll}0 & 0 \\ 0 & 0\end{array}$

$0 \quad 0$

0 o

$0 \quad 0$

$0 \quad 0$

10

$0 \quad 0$

$0 \quad 0$

0

0

$0 \quad 0$

$0 \quad 0$

$0 \quad 0$

$\begin{array}{ll}0 & 0 \\ 0 & 0\end{array}$

$\begin{array}{ll}0 & 0 \\ 0 & 0\end{array}$

$\begin{array}{ll}0 & 0 \\ 0 & 0\end{array}$

$\begin{array}{ll}0 & 0 \\ 0 & 0\end{array}$

$\begin{array}{ll}0 & 0 \\ 0 & 0\end{array}$

$0 \quad 0$

00

$0 \quad 0$

$0 \quad 0$

$\begin{array}{ll}0 & 0 \\ 0 & 0\end{array}$

$\begin{array}{ll}0 & 0 \\ 0 & 0\end{array}$

0

$\begin{array}{ll}0 & 1 \\ 0 & 0\end{array}$

$\begin{array}{ll}0 & 0 \\ 0 & 0\end{array}$

$\begin{array}{ll}0 & 0 \\ 0 & 0\end{array}$

$\begin{array}{ll}0 & 0 \\ 0 & 0 \\ 0 & 0\end{array}$

0

$0 \quad 0$

$0 \quad 0$

$\begin{array}{ll}0 & 0 \\ 0 & 0\end{array}$

$\begin{array}{ll}0 & 0 \\ 0 & 0\end{array}$

0

$\begin{array}{ll}0 & 0 \\ 0 & 0\end{array}$

$\begin{array}{ll}0 & 0 \\ 0 & 0\end{array}$

$0 \quad 0$

$0 \quad 0$

$0 \quad 0$

$0 \quad 0$

$0 \quad 0$

0 0

$\begin{array}{ll}0 & 0 \\ 0 & 0\end{array}$


white males start year=max (非 1 reading + latent +1 , $\$ 3$ reading +1$)$

PERSON-YEARS IN EXPOSURE CATEGORY $3 \quad 5.0$ UP TO 15.0 rems

age

calendar year

$$
-19591960-1964 \quad 1965-1969
$$

$1970-$

TOTAL

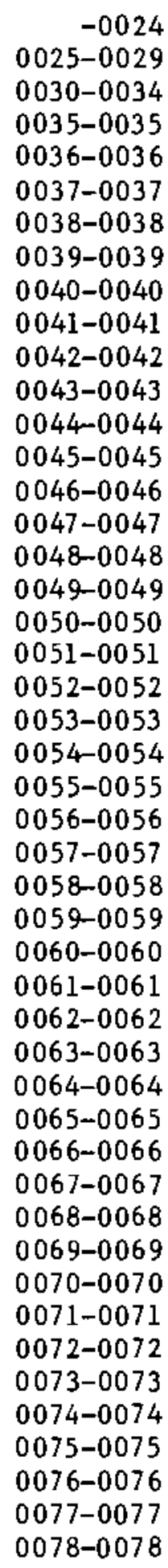

0

0

0

0

0

15

$1 \quad 12$

24

40

45

75

82

95

105

104

91

92

90

86

83

76

72

75

80

84

93

88

84

73

58

45

46

47

39

31

28

22

18

19

20

17

11

11
9

7

7

5

4

1

1

0

1

2191

0
57

0

63

$\begin{array}{rr}62 & 75 \\ 102 & 128\end{array}$

$151 \quad 194$

$207 \quad 254$

$218 \quad 295$

$239 \quad 324$

$275 \quad 374$

$282 \quad 393$

$295 \quad 402$

$314 \quad 409$

$348 \quad 445$

$371 \quad 465$

$382 \quad 474$

$389 \quad 474$

$405 \quad 483$

$397 \quad 474$

$373 \quad 452$

$349 \quad 434$

$341 \quad 434$

$340 \quad 434$

$322 \quad 410$

$315 \quad 403$

$294 \quad 370$

$287 \quad 349$

280

265

247

233

228

214

179

144

126

99

85

71

327

314

294

272

260

243

201

164

145

120

102

63

$47 \quad 55$

$39 \quad 47$

$34 \quad 40$

$22 \quad 26$

22

18

14

23

19

2

96

9563

11852 


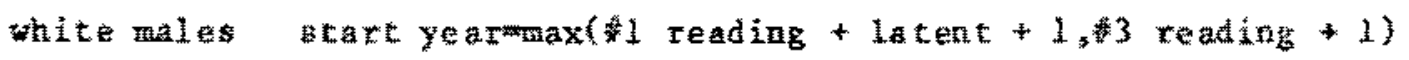

DEATHS FRON ALL CAUSES IN EXPOSURE CATESORY 3

age

calendar yeax

$-1959 \quad 1960-1964 \quad 1965-1969 \quad 1970-\quad$ ToTAL

-0024
$0025-0029$
$0030-0034$
$0035-0035$
$0036-0036$
$0037-0037$
$0038-0038$
$0039-0039$
$0040-0040$
$0041-0041$
$0042-0042$
$0043-0043$
$0044-0044$
$0045-0045$
$0046-0046$
$0047-0047$
$0048-0048$
$0049-0049$
$0050-0050$
$0051-0051$
$0052-0052$
$0053-0053$
$0054-0054$
$0055-0055$
$0056-0056$
$0057-0057$
$0058-0058$
$0059-0059$
$0060-0060$
$0061-0061$
$0062-0062$
$0063-0063$
$0064-0064$
$0065-0065$
$0066-0066$
$0067-0067$
$0068-0068$
$0069-0069$
$0070-0070$
$0071-0071$
$0072-0072$
$0073-0073$
$0074-0074$
$0075-0075$
$0076-0076$
$0077-0077$
$0078-0078$
$0079-0079$
$0080-$

$0 \quad 0$

0

0

$0 \quad 0$

0

0

$0 \quad 0$

0

0

0

0

0

0

0

0

0

0

0

0

0

0

0

0

0

0

0

0

0

1

0

0

0

0

0

0

0

0

0

0

0

0

0

0

0

0

0

0

0

0

1

16

$10 \%$ 
white males start year=max $(\# 1$ reading +1 atent +1 , 非 reading +1$)$

DEATHS FROM ALL CANCERS IN EXPOSURE CATEGORY 3

age

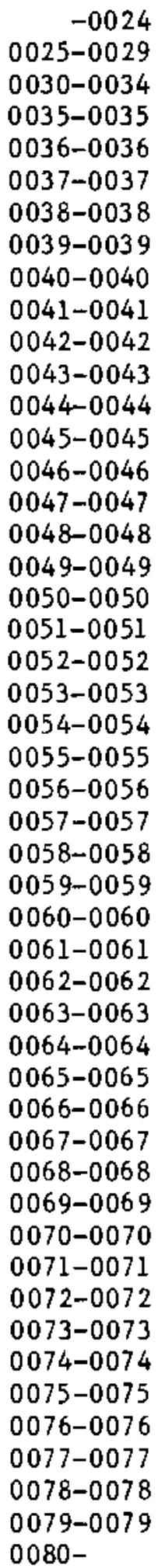

calendar year

$\begin{array}{llll}-1959 & 1960-1964 & 1965-1969 & 1970-\end{array}$

TOTAL

$\begin{array}{ll}0 & 0 \\ 0 & 0 \\ 0 & 0 \\ 0 & 0 \\ 0 & 0 \\ 0 & 0 \\ 0 & 0 \\ 0 & 0\end{array}$

0

0

0

0

0

0

0

0

0

0

0

0

0

0

0

0

0

0

0

0

0

0

0

0

0

0

0

0

0

0

0

0

0

0

0

0
0
0
0
0
0
0
0
0
0

0

0

0

0

0

0

0

0

0

0

0

0

0

0

0

2




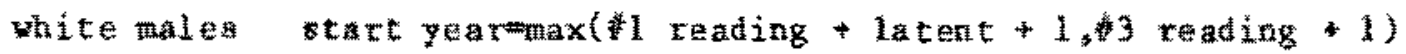

DEATHS FRON Iung canter (162) IN EXPOSURE CATEGORY 3

age

calendar year

$-19591960-1964 \quad 1965-1969 \quad 1970 \mathrm{~m}$

TOTAL

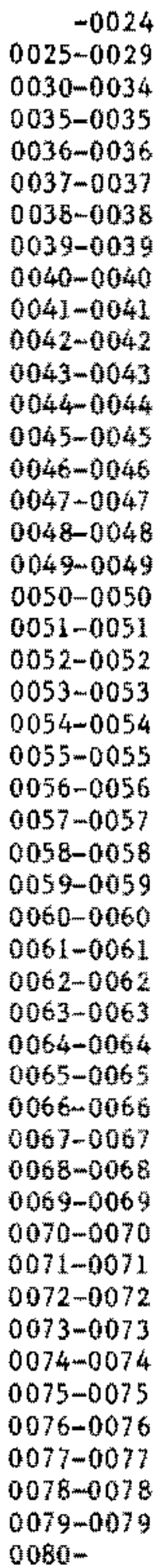

0

0

0

0035-0035

0

0

0

0

0

0

0

0

0 
white males start yearmax( 1 teading + latent $+1,3$ reading +1$)$ PERSON-ZEARS IN EXPOSURE CATEOORY $4=$ OR $\times 15.0$ rens

age

calendar year

$-19591960-1964 \quad 1965-1969 \quad 1970$

TOTAL

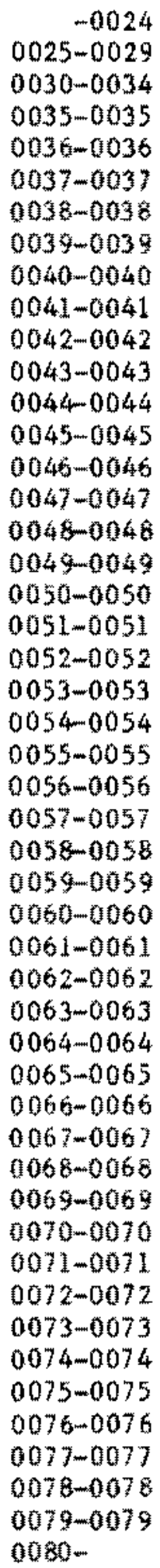

0

0
0
0
0
0
0
0
0

$\begin{array}{lll}0 & 0 \\ 0 & 0 & 0 \\ 0 & 0\end{array}$

$\begin{array}{lll}0 & 0 \\ 0 & 0 & 0 \\ 0 & 0\end{array}$

0

क

$13 \quad 14$

$26 \quad 26$

$41 \quad 42$

$54 \quad 55$

$73 \quad 76$

$104 \quad 106$

$130 \quad 131$

$142 \quad 143$

$159 \quad 161$

$180 \quad 183$

$177 \quad 181$

$179 \quad 180$

$181 \quad 183$

$183 \quad 184$

$178 \quad 178$

$162 \quad 164$

$151 \quad 152$

$151 \quad 153$

$153 \quad 156$

$155 \quad 159$

$153 \quad 15 \%$

$152 \quad 152$

$149 \quad 149$

$146 \quad 146$

$139 \quad 139$

$127 \quad 127$

$120 \quad 121$

$105 \quad 105$

8889

$76 \quad 78$

$70 \quad 71$

$67 \quad 67$

$52 \quad 52$

$37 \quad 37$

$33 \quad 33$

$25 \quad 25$

$18 \quad 18$

$14 \quad 14$

$12 \quad 12$

7 ?

33

33 
white males start yearmax( I reading + latent 1 , 3 reading 1 )

DEATHS FROM ALI CAUSES IN EXPOSURE CATEGORY 素

age

$1950 \quad 1960-1$ calendar year

$-19591960-1964 \quad 1965-196901970 m$

TOTAL.

$-0024$

$0025-0029$

$0030=0034$

$0035-0035$

$0036-0036$

$0037-0037$

$0038-0035$

$0039-0039$

$0040-0040$

$0041-0041$

$0042-0042$

0043-0043

$0044-0044$

$0045=0045$

$0046-0046$

$0047-0047$

$0048-0048$

$0049-0045$

$0050-0050$

$0051-0051$

$0052-005 \frac{2}{2}$

0053-0053

00540054

0055-0055

$0056-0056$

0

00

0

0

0

0

0

$0 \quad 0$

$0 \quad 0$

0

0

0

0

0

(1)

0

0

0

5

0

0

0

0

0

0

0

0

0

0

0

0

0

0

0

$0057-0057$

0058-0058

$0059-0059$

0060-0060

$0061-0051$

$0062-0062$

$0063-0063$

$0064-006$ 布

$0065-0065$

0066 -0066

$0067-0067$

$0068-0068$

0069-0069

0070-0070

$0071-0071$

$0072-0072$

$0073-0073$

$0074 m 0074$

$0075-0075$

0076-0076

$0077-0077$

$0078-0078$

$0079-0079$

$0080-$ 


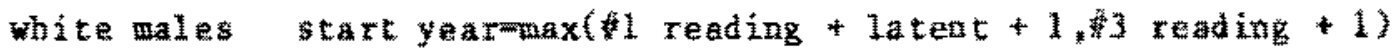

DEATHS FROM ALZ CANCERS IN EXPOSURE CATBGORY 4

age

calendar year

$-19591960-1964 \quad 1965-1969 \quad 1970$

TOTAL

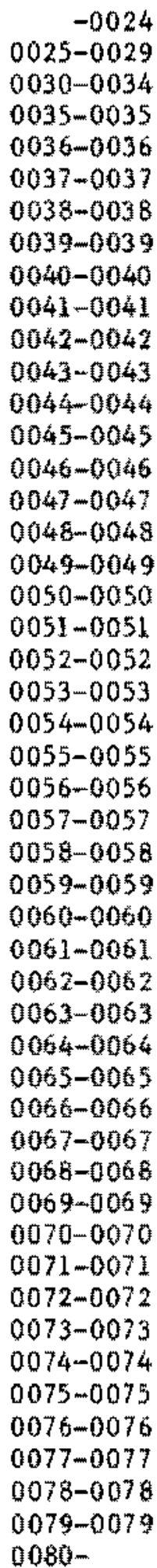

$$
\begin{aligned}
& 0 \\
& 0 \\
& 0
\end{aligned}
$$

0

0

0

0

0

0

0

0

0

0

0

$$
\text { a }
$$$$
\text { a }
$$$$
\text { o }
$$$$
\text { ( }
$$$$
\text { a }
$$$$
0
$$$$
0
$$$$
0
$$$$
0
$$$$
0
$$$$
0
$$$$
0
$$$$
0
$$$$
0
$$$$
0
$$$$
0
$$$$
\text { b }
$$$$
0
$$$$
0
$$$$
0
$$$$
0
$$$$
0
$$$$
0
$$$$
\text { o }
$$$$
0
$$$$
\text { o }
$$$$
0
$$$$
0
$$$$
0
$$$$
0
$$$$
0
$$$$
0
$$$$
0
$$$$
0
$$

$0 \quad 0$

0

0

0

12

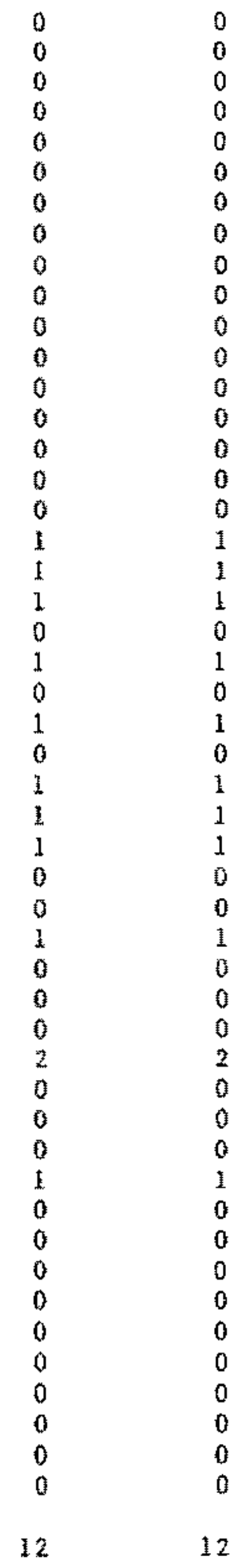


white males start yearmaxt

DEATHS FROM lung cancer (162) IN EXPOSURE CATECORY 4

age

calendar year
$-1959 \quad 1960-1964 \quad 1965-196$

$1970-$

TOTAL

$-0024$

$0025-0029$

$0030-0034$

$0035-0035$

0036-0036

$0037-0037$

$0038-0038$

$0039-0039$

0040-0040

$0041-0041$

$0042-0042$

0043-0043

$0044-0044$

0045-0045

0046-0046

$0047=0047$

$0048-0048$

$0049-0049$

0050-0050

$0051-0051$

$0052-0052$

$0053-0053$

$0054-0054$

$0055-0055$

$0056-0056$

$0057-0057$

$0058-0058$

$0059-0059$

$0060-0060$

$0061-0061$

$0062-0062$

$0063-0063$

0064-006

$0065-0065$

$0066=0066$

$0067-0067$

$0068-0068$

$006 \%-0069$

0070-0070

0071-0071

$0072-0072$

$0073-0073$

0074-0074

$0075-0075$

$0076=0076$

$0077-0077$

$0078-0078$

0079-0079

voon-

0

0
0

0

0

0

0

0

0

0

0

0

0

0

0

0

0

0

0

0

0

0

0

0

0

0

0

0

0

0

0

0

0

0

0

0

0

0

0

0

0

0

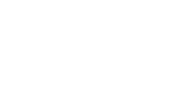

0

0

-

-

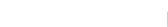

$-2$

0

0

0

0

0

0

0

0

0

0

0

0

0

0

0

0

0

0

0

0

0

0

0

0

0

0

0

0

0

0

0

0

0

0

0

0
0

0

0

0

0

0

0

0

0

0

0

0

0

0

0

0

0

0

0

0

0

0

0

0

0

0

0

0

0

0

0

0

0

0

0

0

0

0

0

0

0

0

0

0

0

0

0

$0 \quad 0$

$0 \quad 0$

$0 \quad 0$

$0 \quad 0$

$0 \quad 0$

$0 \quad 0$

$0 \quad 0$

00

0

0 D

$0 \quad 0$

$0 \quad 0$

$0 \quad 0$

$0 \quad 0$

0

0

$0 \quad 0$

$0 \quad 0$

00

$\begin{array}{ll}1 & 1 \\ 0 & 0\end{array}$

0

0

0

1

0

0 0

$0 \quad 0$

$0 \quad 0$

$0 \quad 0$

00

2

00

0

0

0

0

0

0

0
0

0

0

0

0

5

5 
TOTAI PERSON-YEARS AT RISR

\begin{tabular}{|c|c|c|c|c|c|}
\hline \multirow[t]{2}{*}{ age } & \multicolumn{4}{|c|}{ calendar yeax } & \multirow[b]{2}{*}{ TOTAL } \\
\hline & -1559 & $1960-1964$ & $1965+1969$ & $1970 m$ & \\
\hline-0024 & 0 & 0 & 0 & i & 0 \\
\hline $0025-0029$ & 66 & 92 & 130 & 66 & 354 \\
\hline $0030 m-0034$ & 1146 & 2636 & 1856 & 2904 & 8542 \\
\hline $0035-0035$ & 484 & 1048 & 927 & 1238 & 3697 \\
\hline $0036-0036$ & 594 & 1156 & 1157 & 1412 & 4319 \\
\hline $0037-0037$ & 645 & 1309 & 1347 & 1602 & 4903 \\
\hline $0038-0038$ & 732 & 1339 & 1492 & 1774 & 5337 \\
\hline $0039-0039$ & 796 & 1383 & 1593 & 1893 & 5665 \\
\hline $0040-0040$ & 853 & 1406 & 1658 & 2068 & 5985 \\
\hline $00451-0041$ & 850 & 1433 & 1684 & 2257 & 6224 \\
\hline $0042-0042$ & 852 & 1428 & 1752 & 2400 & 6432 \\
\hline $0043-0043$ & 854 & 1407 & 1776 & 2579 & 6616 \\
\hline $0044-0044$ & 874 & 1419 & 1769 & 2764 & 6826 \\
\hline $0045-0045$ & 861 & 1447 & 1.730 & 2971 & 7009 \\
\hline $0046-0046$ & 796 & 1403 & 1744 & 3146 & 7089 \\
\hline $0047-0047$ & 720 & 1399 & 1713 & 3216 & 7048 \\
\hline 00480048 & 671 & 1345 & 1663 & 3308 & 6987 \\
\hline 00490049 & 629 & 1294 & 1651 & 3311 & 6885 \\
\hline $0050-0050$ & 584 & 1237 & 1635 & 3286 & 6742 \\
\hline $0051-0051$ & 546 & 1143 & 1589 & 3317 & 6595 \\
\hline $0052=0052$ & 496 & 1057 & 1561 & 3277 & 6371 \\
\hline $0053-0053$ & 45 & 973 & 1292 & 3237 & 6147 \\
\hline $0054=0054$ & 402 & 887 & 1445 & 3159 & 3893 \\
\hline $0055-0055$ & 334 & 835 & 1370 & 3097 & 5636 \\
\hline $0056-0056$ & 299 & 775 & 1271 & 3022 & 5367 \\
\hline $0057-0057$ & 292 & 685 & 1173 & 2905 & 5055 \\
\hline 0058-0058 & 307 & 613 & 1074 & 2817 & 4811 \\
\hline 00590059 & 308 & 557 & 976 & 2719 & 4560 \\
\hline $0060-0060$ & 297 & 485 & 316 & 2551 & 4249 \\
\hline $0061-0061$ & 274 & 452 & 844 & 2410 & 3980 \\
\hline $0062-006 \hat{2}$ & 2.59 & 428 & $7 / 45$ & 2258 & 3683 \\
\hline $0063-0063$ & 223 & 432 & 664 & 2105 & 3425 \\
\hline $0064-0064$ & $16 \%$ & 408 & 597 & 1950 & 3141 \\
\hline $0065-0065$ & 172 & 385 & 524 & 1777 & 2858 \\
\hline 00660066 & 138 & 353 & 477 & 1600 & 2568 \\
\hline $0067-0067$ & 122 & 319 & 443 & 1448 & 2332 \\
\hline $0068-0068$ & 122 & 278 & 422 & 1258 & 2080 \\
\hline $0069-0069$ & 113 & 237 & 379 & 1134 & 1863 \\
\hline $0070-0070$ & 95 & 200 & 354 & 995 & 1644 \\
\hline $0071-0071$ & 9 & 166 & 309 & 870 & 1436 \\
\hline $0072-6072$ & 6 & 136 & 258 & 766 & 1253 \\
\hline $0073=0073$ & 63 & 121 & 236 & 656 & 1086 \\
\hline $0074-0074$ & 41 & 114 & 137 & 509 & 931 \\
\hline $0073-0075$ & 32 & 88 & 1.45 & 523 & 738 \\
\hline 00760076 & 17 & 83 & 110 & 463 & 673 \\
\hline $0077-0077$ & 9 & 57 & 99 & 399 & 564 \\
\hline $0078-0078$ & 4 & 48 & 81 & 334 & 467 \\
\hline $0079 m 0079$ & 0 & 30 & 78 & 273 & 381 \\
\hline $0080=$ & 0 & 43 & 215 & 999 & 1257 \\
\hline & 18731 & 36569 & 47340 & 95114 & 197754 \\
\hline
\end{tabular}


TOTAL EXOSURE

ag

$-002$

$0025-0029$

$0030-0034$

$0035-0035$

$0036-0036$

$0037-0037$

$0038-0038$

0039-0039

0040-0040

$0041-0041$

0042-0042

$0043-0043$

$0043-0044$

$0045-0045$

0046 -00

$0047-004$

$0048=0048$

0049-0049

âs0-0050

$0051-0051$

$0052-0052$

0053-003

$0054-0054$

0055.0055

$0056-0056$

$0057-0057$

0058-0058

$0059-0059$

$0060-0060$

$0061-006$

006 2-0062

0063-0063

$0064-0064$

0065-0065

0056 moft5

$0067-005 \%$

$0068+0068$

$0069 \mathrm{~m} 0069$

$0070=0070$

$0071-0071$

$0072-0072$

$0073-0073$

$0074-0074$

$0075-0075$

poty $5=0076$

0077-0077

$0078-0078$

$0079-0079$

$0080-$

\section{$-1959$}

$0.00000+200$

$1.8500 \mathrm{E}+00$

1.14531002

. $8810 \mathrm{E}+01$

1. $7336 \mathrm{E}+02$

2. $4429 \mathrm{E}+02$

$2.7819 \mathrm{E}+02$

2.91095002

$2.60015+02$

$2.7257 \mathrm{E}+02$

2. $7906 \mathrm{E}+02$

2.7932E+02

$2.8755 \mathrm{E}+02$

$2.8644+12$

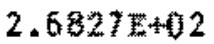

2.5433 整+02

$2.3004+02$

2. $0021 \mathrm{~g}+02$

1. $7968 \mathrm{E}+02$

1.6323 E+02

1. $4334 \mathrm{~s}+02$

1.3964 整+口2

1.23 3502

$9.3820 \mathrm{E}+0 \mathrm{I}$

$6.6580 \mathrm{E}+01$

6. $3260 \mathrm{E}+0$

6. $6220 \mathrm{E}+01$

6.8180 tond

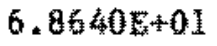

$5.9390 \mathrm{~g}+01$

5. $2220 \mathrm{E}+01$

4.6220E+0I

$3.6710 \mathrm{E}+01$

$3.19600+01$

$3.0760 \mathrm{E}+01$

2.79600 +01

$2.6170 \mathrm{E}+01$

$2.4190 \mathrm{E}+01$

1.9250E+OL

1. $7020 \mathrm{E}+0 \mathrm{I}$

$1.3590 \mathrm{E}+01$

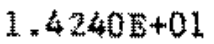

$9.4000 \mathrm{O}+00$

1. $0690 \mathrm{O}+01$

$8.3700 \mathrm{E}+0 \mathrm{O}$

5. $8300 E+00$

1. $3500 \mathrm{E}+00$

$0.0001 \mathrm{E}+00$

$0.0000 \%+00$

$5.4458+03$

calexda year

$1960-1964 \quad 1965-1969 \quad 1970-$

$0.0000 \mathrm{E}+00$

$0.0000 \mathrm{E}+100$

$0.0000 \mathrm{E}+00$

$7.4500 \mathrm{E}+00$

5. 9721.62

3. $3542 \mathrm{E}+\mathrm{CO}$

$3.8569 \mathrm{E}+02$

$4.5904 \mathrm{E}+02$

$5.1554 \mathrm{E}+02$

$6.2962 \mathrm{a}+02$

$7.28 .80+2$

$7.7580 \mathrm{E}+02$

8. $0187 \mathrm{E}+02$

3. $28 \mathrm{~B}+02$

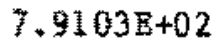

$7.9270 \mathrm{E}+02$

7.8546402

$8.0382+12$

$7.7955+02$

3.8144E+02

$7.8484 \mathrm{E}+02$

$7.4352 \mathrm{E}+02$

$6.8002 \mathrm{E}+02$

6.1316 策+42

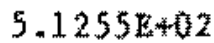

$4.8403 \mathrm{E}+02$

$4.6883 \mathrm{E}+02$

3. $8520 E+02$

$3.4545 \mathrm{E}+02$

$2.9458 \mathrm{E}+02$

2. 4.460 t

$2.0043 \mathrm{E}+02$

1. $9013 \mathrm{E}+02$

2. $1051 \mathrm{E}+02$

2. $0621 \mathrm{E}+02$

1. $8736 \mathrm{E}+02$

$1.5603 \pm+02$

$1.3164+02$

$1.1683 \mathrm{E}+02$

9. $0060 \mathrm{~m}+01$

7.9730E+01

7. $050 \mathrm{E}+0 \mathrm{~L}$

$6.2310 \mathrm{OE}+01$

$5.3170 \mathrm{x}+01$

$5.57 .00+01$

$3.3770 \mathrm{c}+0$

2. $8830 \mathrm{E}+01$

1. $8960 \mathrm{E}+01$

$2,0750 \mathrm{E}+01$

1. $1460 \mathrm{E}+01$

$2.5840 \% 01$

$1.3610 \mathrm{E}+01$

$7.7367 \mathrm{E}+02$

$6.6629 \mathrm{E}+02$

$9.9288 \mathrm{E}+02$

$1.2776 \mathrm{E}+03$

1. $5016 \mathrm{E}+03$

$1.7710 \mathrm{E}+03$

$1.9180 \mathrm{E}+03$

$2.0092 \mathrm{E}+03$

2. $1515 \mathrm{E}+03$

2. $.997 \mathrm{E}+03$

2. $910 \mathrm{E}+03$

2.1706503

$2.0927 \pm+13$

2.0584 然韧

$2.0090 \mathrm{E}+03$

$1.9714 \mathrm{E}+03$

1. $* 16 \mathrm{E}+03$

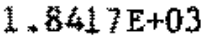

$1.9157 \mathrm{E}+03$

$1.8411 \mathrm{E}+03$

$1.8695 \mathrm{E}+03$

1. $7982 \mathrm{E}+03$

1. $6788 \mathrm{E}+03$

$1.5369 \mathrm{E}+03$

1. $4237 \mathrm{E}+03$

1. $1595 \mathrm{E}+03$

$1.0903 \mathrm{E}+03$

$1.0285 \mathrm{E}+03$

$8.8028 \mathrm{E}+02$

$7.4092 \mathrm{E}+02$

6. $3648 \mathrm{a}+02$

$5.4672 \mathrm{E}+02$

$4.7111 \mathrm{E}+02$

4.3970 E+12

$4.5009 \mathrm{~s}+02$

$3.9361 \mathrm{E}+02$

3. $0064 \mathrm{E}+02$

2. $295 \mathrm{E}+02$

$2,1443 E+02$

$1.9737 \mathrm{E}+02$

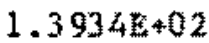

$1.12860+02$

$1.2010 \mathrm{E}+01$

$2.0073 \mathrm{E}+03$

$1.4517 \mathrm{E}+03$

$1.9599 \mathrm{E}+03$

$2.56 .35 \mathrm{E}+03$

$3.2243 E+03$

$3.7294 \mathrm{E}+03$

$4.2785 \mathrm{E}+03$

$5.0179 \mathrm{E}+03$

$5.6483 \mathrm{a}+03$

$6.3627 \mathrm{~N}+03$

7.3500503

$8.2628 \mathrm{E}+03$

$9.0195 \mathrm{E}+03$

$9.4165 \mathrm{E}+13$

$1.0045 \mathrm{E}+04$

$1.018 \mathrm{E}+04$

I.0253 304

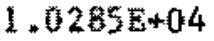

1. $0102 \mathrm{E}+04$

$9.8348 \mathrm{E}+03$

$9.4244 \mathrm{E}+03$

$9.0588 \mathrm{E}+\mathrm{O}^{3}$

8. $33565+03$

$8.7005 \mathrm{E}+03$

$8.450+2+03$

8. 1993 E903

$7.8019 \mathrm{E}+93$

$7.6190 \mathrm{E}+03$

$7.30331+03$

7.004 $\mathrm{E}+03$

6. $006 \mathrm{E}+03$

6. $0080 \mathrm{E}+03$

$5.1604 \mathrm{E} 403$

$4.5293 \mathrm{E}+03$

$3.8003 \mathrm{E}+13$

$3.4905 \mathrm{E}+03$

$3.2152 \mathrm{E}+03$

2.62095+03

2.0 $228 \mathrm{E}+03$

1. $6994+5.3$

1.3221 紫政学

1. $0441 \mathrm{E}+03$

$7.3560 \mathrm{E}+01$

\%.2226E+02

$6.4310 \mathrm{E}+01$

$6.8121 \mathrm{E}+02$

4. $915 \mathrm{E}+02$

4.7210E+01

蛙毒 $700 \mathrm{E}+01$

$3.0194 \mathrm{E}+02$

$8.3370 \mathrm{E}+01$

$6.5253 E+12$

$0.0000 \mathrm{E}+00$

$3.4920 \mathrm{E}+01$

$3.4927 \mathrm{E}+0.3$

$2.5523 \mathrm{E}+03$

$3.5198 \mathrm{E} * 03$

$4.5444 \mathrm{E}+03$

$5.5226 E+03$

$6.4211 \mathrm{E}+03$

$7.1937 \mathrm{E}+03$

$8.0755 \mathrm{E}+03$

$8.8908 \mathrm{E}+03$

$9.6200 \mathrm{E}+03$

$1.0624 \mathrm{E}+04$

$1.1513 \mathrm{E}+04$

$1.2166 \mathrm{E}+04$

$1.2533 \mathrm{E}+0.4$

$1.3064 \mathrm{E}+0 \mathrm{4}$

$1.3137 \mathrm{E}+04$

1. $3099 \mathrm{E}+04$

$1.3033 \mathrm{E}+04$

$1.2841 \mathrm{E}+04$

$1.2429 E \div 04$

$1.1930 \mathrm{E}+04$

$1.1435 \mathrm{E}+04$

1. $1150 \mathrm{z}+04$

1. $0655 \mathrm{E}+04$

$1.02835+04$

$9.72155+03$

$9.2054 \mathrm{E}+03$

$8.9079 \mathrm{E}+03$

$8.4259 \mathrm{E}+03$

$8.00172+03$

$7.37208+03$

$6.7740 \mathrm{E}+03$

$5.8183 \mathrm{E}+03$

$5,1286 \mathrm{E}+03$

4. $3934 \mathrm{E}+03$

$3.9984 \mathrm{E}+0.3$

$3.6228 \mathrm{E}+03$

2.96175403

2. $3131 \mathrm{E}+03$ 
TOTAI EX EOSURE**2

age

$-0025$

0025-0029

$0030-0034$

$0035-0035$

$0036-0036$

0037-0037

$0038-0038$

$0039-0039$

$0040-0040$

0041-0041

$0042-0042$

0043-0043

$0044-0044$

$0045-0045$

0046-0045

0047-00赫

$0048-1048$

0049-0049

0050-0050

$005 k-0051$

0052-0052

$0053-0053$

$0054-0054$

$0055-0055$

$0056-0056$

$0057-0057$

$0058-0058$

00590059

$0060 \mathrm{~m} 0060$

$0051-0061$

0062-0062

0063-0063

$0064-0064$

0065-0065

0068-0066

0067-006

0068-0068

0069-0069

0070-0070

$0071-0071$

$0072-0072$

$0073-0073$

0074-0074

0075-007s

$0076-0076$

0077-0077

$007 \mathrm{~B}-0078$

0079-0079

0080 -

\section{$-1959$ \\ calendat year \\ 1960-1964 1965-1969}

$0.0000 \mathrm{E}+00$

$2.6710 \mathrm{x}-01$

$5.9355 \mathrm{E}+01$

$1.0114 \mathrm{E}+02$

$2.4938 \mathrm{E}+02$

$3.6829 \mathrm{E}+02$

$4.4097 \mathrm{E}+02$

4. $3305 \mathrm{E}+02$

3. $3105 \mathrm{E}+02$

$3.4836 \mathrm{E}+02$

$3.4853 E+02$

$3.2915 \mathrm{E}+02$

$3.4301 \mathrm{E}+02$

3. $3202 \mathrm{E}+02$

$3.13305+02$

$3.0376 \mathrm{E}+02$

$2.5877 \mathrm{E}+02$

$2.1624 \mathrm{E}+02$

$1.9304 \mathrm{E}+02$

$1.6054 \mathrm{E}+02$

$1.45472+02$

$1.509 \mathrm{E}+02$

$1.286 \mathrm{E}+02$

$9.6273 \mathrm{E}+01$

$5.4093 \mathrm{E}+01$

$4.8659 \mathrm{E}+01$

$5.172 .4 \mathrm{E}+01$

$6.4880 \mathrm{E}+01$

$6.8227 \mathrm{E} \div 01$

$4.69435+01$

$4.3706 \mathrm{E}+01$

$3.7388 \mathrm{E}+01$

$2.6727 \mathrm{E}+0 \mathrm{I}$

$2.5255 \mathrm{E}+01$

$2.6611 \mathrm{E} \div 01$

2. $2091 \mathrm{E}+01$

$1.9789 \mathrm{E}+01$

1. $9282 \mathrm{E}+01$

$2.0098 \mathrm{E}+01$

1. $9692 \mathrm{E}+0$ l

$1.5212 \mathrm{E}+01$

1. $91.12 \mathrm{E}+01$

9. $1290 \mathrm{~F}+00$

1.11 絫然 +01

$1.1103 \mathrm{E}+01$

9. $3483 \mathrm{E}+00$

$9.0530 \mathrm{E}-01$

$0.0000 \mathrm{E}+00$

$0.0000 \mathrm{E}+00$

6.3229003

$0.0000 \mathrm{E}+00$

$0.0000 \% 400$

$5.7011 E+00$

$3.9449 \mathrm{E}+00$

$5.3420 \mathrm{E}+02$

$3.8844 \mathrm{E}+02$

$4.7608 \mathrm{E}+02$

$5.7603 E+02$

6. $8402 \mathrm{E}+02$

$9.5105 \mathrm{E}+02$

$1.25738+03$

$1.295 \mathrm{BE}+03$

$1.4009 \mathrm{E}+03$

$1.2940 \mathrm{E}+03$

$1.3125 \mathrm{E}+03$

$1.2773 \mathrm{E}+03$

$1.214 .45+03$

$1.3252 \mathrm{E}+03$

$1.2355 \mathrm{~B}+0.3$

1. $2634 \mathrm{E}+03$

1. $3836 \mathrm{E}+03$

$1.4408 \mathrm{E}+03$

$1.2845 \mathrm{E}+03$

$1.1335 \mathrm{E}+03$

$7.7401 \mathrm{E}+02$

$7.5038 \mathrm{E}+02$

$8.1037 \mathrm{E}+02$

$6.0434 \mathrm{E}+02$

$6.0045 \mathrm{E}+02$

4. $6411 \mathrm{E}+02$

$3.8812 \mathrm{z}+02$

$2.5055 \mathrm{E}+02$

$2.3936 \mathrm{E} .02$

$3.0278 \mathrm{E}+02$

$3.3551 \mathrm{E}+02$

$2.9775 \mathrm{E}+02$

$2.3407 \mathrm{E}+02$

$1.5329 \mathrm{E} 402$

$1.65075 * 02$

$9.4710 \mathrm{E}+01$

$8.0910 \mathrm{E}+01$

$7.8587 \mathrm{E}+01$

B. $4.991 \mathrm{E}+01$

$8.6925 \mathrm{E}+01$

$1.2416 \mathrm{E}+02$

$4.31515+01$

$3.9479 \mathrm{E}+01$

2. $4129 \mathrm{E}+0 \mathrm{I}$

$3.6933 \mathrm{E}+01$

2. $3383 \mathrm{E}+01$

8,0121E+01

$1.3106 \mathrm{E}+03$

1. $6926 \mathrm{E}+03$

2. $7738 \mathrm{E}+03$

3. B $348 \mathrm{E}+03$

$5.0363 \mathrm{E}+03$

$6.8535 \mathrm{E}+03$

8.02708003

8.98165403

$1.0257 \mathrm{E}+04$

1. $.0709 E+04$

$1.0132 \mathrm{E}+04$

$9.6424 \mathrm{E}+03$

$8.9540 \mathrm{~s}+03$

$8.7559 \mathrm{~g}+03$

$8.5961 \mathrm{E}+03$

$8.5090 \mathrm{E}+03$

7. $4870 \mathrm{E}+03$

$7,2855 \mathrm{E}+03$

$8.154420+03$

$7.5137 \mathrm{C}+03$

$8.3147 \pm+03$

6.7006 +03

$8.6201 \mathrm{E}+03$

$7.6543 \mathrm{E}+03$

$7.5466 \mathrm{E}+03$

$4.7985 \mathrm{E}+03$

$4.4077 \mathrm{E}+03$

$4.3449 \mathrm{E}+03$

$3.7000 \mathrm{E}+03$

$3.2106 \mathrm{E}+03$

3. $0129 \mathrm{E}+03$

$2.3603 \mathrm{E}+03$

$1.9795 \mathrm{E}+03$

$1.9609 \mathrm{E}+03$

$2.3189 \mathrm{E}+03$

1. $9991 \mathrm{E}+03$

1. $2325 \mathrm{E}+03$

8. $8447 \mathrm{E}+02$

$6.1717 \mathrm{E}+02$

$7.1730 \mathrm{E}+02$

$4.2466 \mathrm{E}+02$

$3.1817 \mathrm{E}+02$

1. $7983 \mathrm{E}+02$

$1.6936 \mathrm{E}+02$

1. $3336 \mathrm{E}+02$

$1.3651 \mathrm{E}+02$

$1.77715+02$

$0.0000 \mathrm{E}+00$

$1.2441 \mathrm{E}+01$

$5.5461 \mathrm{~B}+03$

$5.6646 \mathrm{~B}+03$

$9.125 \mathrm{EE}+03$

$1.3229 \mathrm{E}+04$

$1.9101 \mathrm{E}+0.5$

$2.4764 \mathrm{E}+64$

$3.1208 \mathrm{E}+04$

$3.9913 E+04$

$4.8859 \mathrm{E}+04$

$5.9181 \mathrm{E}+04$

$7.5680 \mathrm{E}+04$

$9.0015 E+04$

$1.0255 \mathrm{E}+0 \mathrm{5}$

$1.1009 \mathrm{E}+0 \mathrm{~S}$

$1.2416 \mathrm{E}+05$

1. $275 \mathrm{EE}+05$

1. $3536 \mathrm{E}+05$

$1.3697 \mathrm{E}+05$

$1.3800 \mathrm{E} 405$

$1.3234 \mathrm{E}+05$

$1.2329 \mathrm{E} \div 05$

$1.1661 \mathrm{E}+03$

1. $1328 \mathrm{BE}+05$

1. $13928+05$

$1,1112 \mathrm{E}+05$

$1.0522 \mathrm{E}+05$

$1.01855+05$

$1.05248+05$

$1.0135 \mathrm{E}+05$

$1.0030 \mathrm{E}+05$

$9.7596 \mathrm{E}+04$

$9.1580 \mathrm{E}+04$

7.49175404

$6.5073 \mathrm{E}+0.4$

$5.3094 \mathrm{E}+04$

4. $9350 \mathrm{E}+04$

4. $8664 \mathrm{E}+04$

$3.9052 \mathrm{E}+04$

2. $8121 \mathrm{E}+04$

$2.3680 \mathrm{E}+04$

$1.5657 \mathrm{E}+0.4$

1. $2383 \mathrm{E}+0.4$

$8.70408+03$

$7+2775 \mathrm{E}+03$

$4.8755 E+03$

$2.1142 \mathrm{E}+03$

$2.26495+03$

$0,0000 \mathrm{E}+00$

$2.2354 \mathrm{E}+01$

$7.4502 \mathrm{E}+0.3$

$7.6468 \mathrm{E}+03$

$1.2625 \mathrm{E}+04$

$1.8008 \mathrm{E}+04$

$2.5262 \mathrm{E}+104$

$3.3001 \mathrm{E}+04$

$4.0823 \mathrm{E}+04$

$5.0538 \mathrm{E}+04$

$6.0655 \mathrm{E}+04$

$7.1313 \mathrm{~B}+04$

$8.7467 \mathrm{E}+04$

$1.0127 \mathrm{E}+0 \mathrm{~s}$

$1.1303 \mathrm{E}+0.5$

$1.2048 \mathrm{E}+05$

$1.342 \$ B+05$

1. $3744 \mathrm{E}+05$

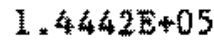

$1.4586 E+0.5$

$1.4758 \mathrm{E}+0.5$

1. $4114 \mathrm{E}+0 \mathrm{~S}$

1. $3251 \mathrm{E}+05$

$1.2616 \mathrm{E}+05$

1.2.276505

$1.22230+05$

$1.19328+05$

1. $1055 E+05$

$1.0671 \mathrm{E}+0.5$

$1.0988 \mathrm{E}+05$

$1.0533 \mathrm{E}+05$

$1.03855+05$

$1.0097 \mathrm{E}+05$

$9.42636+04$

$7.7157 \mathrm{E}+04$

$6.7209 E+04$

$5.5598 \mathrm{E}+04$

$5.1463 \mathrm{E}+04$

$4.9991 \mathrm{E}+04$

$4.0035 E+04$

$2.88395+04$ 
ge

-0024
$0025-0029$
$0030-0034$
$0035-0035$
$0036-0036$
$0037-0037$
$0038-0038$
$0039-0039$
$0040-0040$
$0041-0041$
$0042-0042$
$0043-0043$
$0044-0044$
$0045-0045$
$0046-0046$
$0047-0047$
$0048-0048$
$0049-0049$
$0050-0050$
$0051-0051$
$0052-0032$
$0053-0053$
$0054-0054$
$0055-0055$
$0056-0056$
$0057-0057$
$0058-0058$
$0059-0059$
$0060-0060$
$0061-0061$
$0062-0062$
$0063-0063$
$0064-0064$
$0055-0065$
$0066-0066$
$0067-0067$
$0068-0068$
$0069-0059$
$0070-0070$
$0071-0071$
$0072-0072$
$0073-0073$
$0074-0074$
$0075-0075$
$0076-0076$
$0077-0077$
$0078-0078$
$0079-0079$
$0080-$

calenda year

$-1959 \quad 1950-1964 \quad 166 \%-1969 \quad 1970-$

$0.0000 \mathrm{E}+00$

$5.64+3$

6. $14645+01$

1. $7310 \mathrm{E}+02$

$5.5021 \mathrm{E}+02$

8. $4690 \mathrm{E}+02$

1. $0710 \mathrm{0E}+03$

1. $0065 \mathrm{E}+03$

6. $398 \mathrm{C}+62$

8. 285 , + + 2

$8.2123 \mathrm{E}+02$

$6.0283 \mathrm{E}+02$

6. $4013 \mathrm{E}+02$

$5.1607 \mathrm{E}+02$

$6.0732 \mathrm{z}+02$

5. $69180+02$

$4.6662 \mathrm{z}+02$

$3.7637 \mathrm{E}+02$

$3.3891 \mathrm{E}+02$

$2.4881 \mathrm{E}+02$

$2.3071 \mathrm{E}+02$

$2.6321+02$

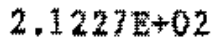

1. $5414 \mathrm{E}+02$

$6,7457 \mathrm{E}+01$

$5.8777 \mathrm{E}+01$

$7.09565+01$

1.3609 +02

$1.5638 \mathrm{E}+02$

$6.5683 \mathrm{~s}+0$

$8.0776 \mathrm{E}+\mathrm{OI}$

$6.9919 \mathrm{E}+\mathrm{DL}$

3. $9220 \mathrm{E}+01$

$4.3572 \mathrm{E}+01$

$4.5542 \mathrm{E}+01$

$2.8746 \mathrm{a}+01$

$2.4137 \mathrm{~s}+01$

$2.4870 \mathrm{E}+01$

$4.3214 \mathrm{~F}+01$

4. $7057 \mathrm{E}+0$

$3.9919 \mathrm{E}+01$

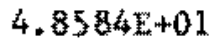

1.493601

$1.75658+01$

1. $.9611 \mathrm{E}+01$

$2.0979 \mathrm{E}+\mathrm{OI}$

$6.6208 \mathrm{E} \times 01$

$0.0000 \mathrm{E}+00$

$0.0000+00$

$1.2527 \mathrm{E}+04$
$4.3628 \mathrm{E}+00$

$9.6642 E+02$

$9.0327 \mathrm{E}+02$

$1.1838 \mathrm{E}+03$

1. $4790 \mathrm{E}+03$

1. $7302 \mathrm{E}+03$

$2.5217 \mathrm{E}+03$

3.731 .5203

$3.4940 \mathrm{E}+03$

4. $0757 \mathrm{E}+03$

$3.5324 \mathrm{E}+03$

$3.8687 \mathrm{E}+03$

$3.833 \mathrm{E}+03$

$3.171 .72+03$

$3.9314 \mathrm{E}+03$

$3.1436 \mathrm{E}+03$

$3.2521 \mathrm{E}+03$

a. $1077 \mathrm{E}+03$

5. $1703 \mathrm{E}+03$

$4.4833 \mathrm{E}+03$

$3.9575 \mathrm{E}+03$

$1.954002+03$

1.8747003

$2.3916 \mathrm{E}+03$

1.6171E403

I. $833 \mathrm{~s}+03$

$1.3502 \mathrm{w}+13$

1. 233 然 +03

5.7390002

$5.6343 \mathrm{E}+02$

$7.9191 \mathrm{E}+02$

$1.0190 \mathrm{E}+03$

8. $7480 \mathrm{E}+02$

$7.26255+02$

$3.3949 \mathrm{E}+02$

$4.7691 \mathrm{eq2}$

$1.9050 \mathrm{E}+02$

$1,2688 \mathrm{E}+02$

$1 \times 4457 \mathrm{E}+02$

$2.2035 \mathrm{E}+02$

$3.5819 \mathrm{~g}+02$

6.7650 w02

$9.6891+01$

$9.3501 \mathrm{E}+01$

5. $7002 \mathrm{E} \div 01$

1. $0564 \mathrm{E}+02$

$8.3762 \mathrm{z}+01$

3.642602

$8.2770 \mathrm{5}+04$
$0.0000 \mathrm{E}+00$
$0.00005+00$

$3.3719 \mathrm{E}+00$

$3.7663 \mathrm{E}+03$

$7.2774 \mathrm{E}+03$

1. $32.5 \mathrm{E}+04$

i. $930 \mathrm{OE}+04$

$3.0769 \mathrm{E}+04$

4. $5914 \mathrm{E}+0$ 年

5.7101004

$6.82 \mathrm{~J} 4 \mathrm{E}+\mathrm{O} 4$

8. $2213 E+04$

$9.0245 \mathrm{E}+04$

8. $0539 \mathrm{E}+04$

$7.2585 \mathrm{E}+04$

$6.671 .4 \mathrm{E}+04$

$6.7404 \mathrm{E}+04$

$6.8021 \mathrm{E} * 04$

$6.9762 \mathrm{E}+04$

5. $5183 \mathrm{E}+04$

5. $203 E+04$

$6.13148+04$

$5.0226 \mathrm{E}+04$

6.1860 整+口素

$7.2470 \mathrm{E}+04$

$7.8189 \mathrm{E}+04$

$6,671 \mathrm{E}+04$

$7.3998 \mathrm{E}+04$

$3.6252 \mathrm{E}+0$

$3.1292 \mathrm{E}+\mathrm{O}^{4}$

3.2311 管 +4

2.7232 些地毒

$2.4735 E+04$

2. $6190 \mathrm{E}+04$

$2.00708+04$

$1.5713 \mathrm{E}+04$

$1.63 \widehat{G 2} \mathrm{E}+4$

$2.28345+04$

1.8587 E0

马. $8679 \mathrm{E}+03$

b. $996 \mathrm{E}+03$

$3.5026 \mathrm{E}+0.3$

5. $44608+03$

2.9516 w03

$1.7421 \mathrm{t}+03$

1. $0566 \mathrm{E}+03$

1. $0277 \mathrm{E}+03$

4. $2092 \mathrm{E}+02$

$9.4374 \mathrm{E}+02$

$7.0238 \mathrm{E}+02$

$1.72004+06$
$0.0000 \mathrm{E}+00$

$2.0575 \mathrm{E}+0$.

2.5674E+

$3.4783 \mathrm{E}+04$

$6.6079 \mathrm{E}+04$

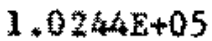

1.7061 $8+05$

2. $4940 \mathrm{E}+05$

$3.5215 \mathrm{E}+05$

$4.9475 \mathrm{E}+\mathrm{O}$

$6.632 \mathrm{E}+05$

8.6324 $4+05$

1. $107 \mathrm{E}+06$

$1.5065 \mathrm{E}+06$

$1.7997 \mathrm{E}+06$

1.9798 406

$2.3555 \mathrm{E}+0 \mathrm{E}$

2. $483 \mathrm{k}+06$

$2.8106 \mathrm{E}+06$

2. $8964 \mathrm{~g}+06$

$3.0095 \mathrm{z}+06$

$2.8594 \mathrm{E}+06$

$2.6245 \mathrm{E}$ 埋

$2.4349 \mathrm{E}+06$

2. $2561 \mathrm{E}+06$

2. $3605 \mathrm{E}+06$

$2.3255 \mathrm{E}+06$

2. $1090 \mathrm{E}+06$

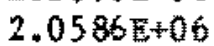

$2.2798 \mathrm{E}+0$

$2.1868 \mathrm{E}+0 \mathrm{6}$

$2.2456 \mathrm{E}+06$

2. 2 . $4 \mathrm{E}+06$

2. $20532+06$

1.73838+06

$1.4836 \mathrm{E}+06$

$1.1904 \mathrm{E}+06$

$1.1097 \mathrm{E}+06$

1.13 $76 \mathrm{E}+06$

9. $36125+05$

$6.624,5+05$

$5.71325+05$

$3.26992 \times 0$

$2.6104 \mathrm{E}+4$

$1.6035 \mathrm{E}+\mathrm{S}$

$1.3542 \mathrm{E}+05$

$8.31779+04$

$2.8955 \mathrm{E}+14$

$2.2372 \mathrm{E}+04$

$6.3160 \mathrm{E}+27$
$0.0000 \mathrm{E}+00$

$2.8366 \mathrm{E}+01$

$3.0468 \mathrm{E}+04$

$4.3136 \mathrm{E}+04$

$8.105 \mathrm{BE}+04$

$1.2407 \mathrm{E}+05$

$2.0418 \mathrm{E}+05$

$2.9835 E \div 05$

$4.1366 \mathrm{E}+05$

$5.6729 \mathrm{E}+0$

$7.5043 E+05$

$9.5762 \mathrm{E} * 05$

$1.2958+06$

$1.58352+06$

$1.8701 \mathrm{E}+06$

$2.0517 \mathrm{E}+06$

$2.4271 \mathrm{E}+0 \mathrm{E}$

$2.5217 \mathrm{E}+06$

$2.8702 \mathrm{E}+06$

$2.9530 \mathrm{E}+06$

$3.0755 \mathrm{E}+06$

$2.9138 \mathrm{E}+06$

$2.6885 E+06$

$2.5094 \mathrm{E}+06$

$2.3667 \mathrm{E}+06$

2. $42.9 \mathrm{E}+06$

$2.40062+06$

$2.1468 \mathrm{E}+06$

$2,0913 E+06$

$2.3127 \mathrm{E}+06$

2.2147 E+06

$2.2712 \mathrm{E}+06$

2.3056006

$2.22635+06$

$1.7548 \mathrm{E}+06$

$1.5003 \mathrm{E}+06$

$1.2137 \mathrm{E}+06$

$1.1285 \mathrm{E}+06$

$1.1576 \mathrm{E}+06$

$9.43118 * 05$

$6.6626=05$

$5.7717 \mathrm{E}+05$

$3.3063 E+05$

$2.6290 \mathrm{E}+05$

1. $6152 \mathrm{E}+05$

$1.3653 \mathrm{E}+0.5$

8. $920505+04$

$2.9983 \mathrm{E}+04$

$2.3438 \mathrm{E}+04$

$6.4975 \mathrm{E}+10$ 
g g fa calendst yax

$1999 \quad 1960-1964 \quad 1965-3969 \quad 1970-$

$0.0000 \mathrm{E}+000$

$1.3336 \mathrm{E}-02$

$8.7711 \mathrm{E} * 01$

$3.6399 \mathrm{E}+02$

$1.5196 \mathrm{E}+03$

$2,4203 \mathrm{E} * 03$

$3.2359 \mathrm{E} * 03$

$2.9518 \mathrm{~s} * 03$

$1,8193 \mathrm{E}+03$

$2.9863 \mathrm{E}+\mathrm{Da}$

$3.0281 \mathrm{E}+03$

$1.3947+403$

$1,4878 \mathrm{E}+03$

$1.5041 \mathrm{E}+03$

$1.5701 \mathrm{E}+03$

$1.3803 E+03$

$1.0884 \mathrm{E}+03$

$8.27090+02$

$7.7000 \mathrm{E}+02$

毒. $8932 \mathrm{E}+02$

$4.6405 \mathrm{E}+02$

$5.7543 \mathrm{E}+0.2$

$4.2986 \mathrm{E}+02$

$3.0643 \mathrm{~B}+02$

$1.0177 \mathrm{E}+02$

$8.6353 \mathrm{E}+01$

$1.2834 \mathrm{E}+02$

$4.41698+02$

$5.4970 \mathrm{E}+02$

$1.2135 \mathrm{E}+02$

2.2.1. 2E+02

$2,0154 E+02$

$8.0108 \mathrm{E}+0 \mathrm{I}$

$1.0221 \mathrm{E}+02$

$1.0447 \mathrm{E}+02$

$4.6420 \mathrm{E}+01$

$3.5492 \mathrm{E}+01$

3.7686501

$1.18511+02$

$1.3923 \mathrm{E}+02$

$1.2 \% 616+02$

$1.4535 E+02$

2. $3003 \mathrm{E}+01$

$3.2316 \mathrm{E}+01$

$3.8198 \mathrm{E}+01$

$5.1741 \mathrm{E}+01$

$5.0521 \mathrm{E}-01$

$0.0000 \mathrm{E}+00$

$0.0000 \mathrm{E}+00$

$0.0000 E+00$

$6.2634 \mathrm{E}+00$

$2.5701 \mathrm{E}+03$

$3.1756 \mathrm{E}+03$

$4.1584 \mathrm{E}+03$

$5.4070 \mathrm{E}+03$

$6.0549 \mathrm{E}+03$

$8.8191 \mathrm{E}+03$

1. $4894 \mathrm{E}+04$

1. $1946 \mathrm{E}+04$

$1.5 .598 \mathrm{E}+0.4$

$1.2655 \mathrm{E}+04$

$1.5984 \mathrm{E}+04$

$1.8726 \mathrm{E}+04$

$1.1403 \mathrm{E}+04$

$1.6745 \mathrm{E}+04$

$1.0448 \mathrm{E}+04$

$1.0857 \mathrm{E}+04$

$1.6908 \mathrm{E}+04$

$2.8103 \mathrm{E}+04$

$2.3172 \mathrm{E}+04$

$1.9883 \mathrm{E}+04$

$7.0992 \mathrm{E}+03$

$5.9779 \mathrm{E}+03$

$9.3671 \mathrm{E}+03$

$5.8043 \mathrm{E}+03$

$8 * 1196 \mathrm{E}+03$

$5.6078 \mathrm{E}+03$

$5.7286 \mathrm{E}+03$

$1.8378 \mathrm{E}+03$

$1.8616 \mathrm{E}+03$

$2.79038+03$

$4.1458 \mathrm{E}+03$

3. $3203 \mathrm{E}+03$

$3.0673 E+03$

$1.0424 \mathrm{E}+03$

$1.8562 \mathrm{E}+03$

$5.6887 \mathrm{E}+02$

2. $5032 \mathrm{E}+02$

$3.4303 E+02$

$0.0377 \mathrm{E}+02$

$2.08642+03$

$4.9359 \mathrm{E}+03$

$2.6362 \mathrm{E}+02$

$2.5978 \mathrm{E}+02$

$1.6440 \mathrm{E}+02$

3. $4337 \mathrm{E}+02$

$3.4209 \mathrm{E}+02$

$1.7655 \mathrm{E} \div 03$

0.0000000

$2.2942 \mathrm{E}+00$

$1.4332 \mathrm{E}+\mathrm{DA}$

$4.1000 \mathrm{E}+04$

$8.4710 \mathrm{E}+04$

$1.3037 \mathrm{E}+0.5$

$2.6627 \mathrm{E}+0.5$

4. $111 \mathrm{BE}+05$

$5.1834 \mathrm{E}+05$

$6.5724 \mathrm{E}+05$

$8.2459 \mathrm{E}+05$

$9.582 .3 \mathrm{E}+05$

$8.1063 \mathrm{E}+05$

$6.9281 \mathrm{et} 05$

$6.3719 \mathrm{E}+05$

$6.8031 \mathrm{E}+05$

$7.1910 \mathrm{E}+05$

$7.7580 \mathrm{E} 405$

$5.5107 \mathrm{E} 405$

4.74885805

$6.09700+05$

$4.1635 \mathrm{E}+05$

$5.3527 \mathrm{E}+0.5$

$7.6906 \mathrm{E}+05$

$9.3245 \mathrm{E}+05$

$7.3569 \mathrm{E}+05$

$8.9185 \mathrm{E}+0.5$

$3.6612 \mathrm{E}+05$

2. $8124 \mathrm{E}+05$

$3.0621 \mathrm{E} .05$

2.5111 E+05

$2.31710+05$

$2.82 .31 \mathrm{E}+0.5$

$2.23578+05$

$1.5372 \mathrm{E}+05$

$1.6991 \mathrm{k}+05$

$2.8248 \mathrm{E}+05$

$2.08778+05$

$1.0011 \mathrm{x}+05$

$7.2300 \mathrm{E} 404$

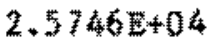

$5.4618 \mathrm{E}+04$

2. $975 \mathrm{BE}+04$

$1.2321 \mathrm{E}+04$

$8.5721 \mathrm{E}+03$

$8.4440 E+03$

$8.068 .5 \mathrm{E}+0.3$

$8.1647 \mathrm{E}+03$

$3.1815 \mathrm{E}+03$

$0.0000 \mathrm{E}+00$

$3.8914 \mathrm{E}+01$

$1.5209 \mathrm{E}+05$

$2.6444 E+05$

$5.9086 \mathrm{E}+0 \mathrm{~S}$

$9.5801 \mathrm{E}+05$

$1.8646 \mathrm{E}+06$

$3.0320 \mathrm{E}+06$

4.83142006

$7.4737 \mathrm{E}+06$

$1.1031 \mathrm{E}+07$

$1.5307 \mathrm{E}+07$

$2.3405 \mathrm{E}+07$

$2.9994 \mathrm{E}+07$

$3.7579 \mathrm{E}+07$

$4.2409 \mathrm{E}+07$

$5.3199 \mathrm{E}+07$

$5.5783 \mathrm{E}+07$

$7.0943 \mathrm{E}+07$

$7.4487 \mathrm{E}+07$

$7.9276 \mathrm{E}+07$

$7.4673 \mathrm{~B}+09$

$6.8465 \mathrm{~B}+07$

$6.2227 \mathrm{E}+07$

$5.5586 \mathrm{E}+07$

$5.8718 \mathrm{E}+07$

$5.8266 \mathrm{E}+07$

$5.0343 \mathrm{E}+0$ ?

$4.93448+07$

$5.9456 \mathrm{E}+07$

$5.6302 \mathrm{E}+07$

$6.00052+07$

$6.3519 E+07$

$6.3116 \mathrm{E}+07$

$4.8093 \mathrm{E}+0$ ?

$3.9179 \mathrm{E}+07$

$3.0877 \mathrm{E}+07$

$2.8827 \mathrm{E}+0$ ?

$3.0815 \mathrm{E}+07$

$2.5753 \mathrm{~B}+07$

$1.7941 \mathrm{E}+0.7$

$1.6060 \mathrm{E}+07$

$8.1845 \mathrm{E}+06$

$6.3951 \mathrm{E}+06$

$3.4286 \mathrm{E}+06$

$2.9113 \mathrm{E}+0 \mathrm{G}$

1. $8574 \mathrm{E}+06$

$4.6674 \mathrm{E}+05$

$2.9979 E+05$

$0.0000 \mathrm{~B}+00$

$4.7485 \mathrm{E}+01$

$1.6908 \mathrm{E}+05$

$3.0898 \mathrm{E}+05$

$6.8124 \mathrm{E}+05$

$1.0962 \mathrm{E}+06$

2. $1401 \mathrm{E}+06$

$3 * 45492 \div 06$

$5.3665 \mathrm{E}+06$

$8.1 .4595 * 06$

$1.1874 E+07$

$1.6279 \mathrm{E}+07$

$2.4233 \mathrm{E}+07$

$3.0707 \mathrm{E}+07$

$3.8230 \mathrm{E}+07$

4. $3108 E+07$

$5.3930 \mathrm{E}+07$

$5.6571 \mathrm{E}+07$

$7.1511 \mathrm{E}+07$

$7.4991 \mathrm{E}+07$

$7.9910 \mathrm{E}+07$

$7.51 .10 \mathrm{~B}+07$

$6.9058 \mathrm{E}+07$

$6.3003 \mathrm{E}+07$

$5.6528 \mathrm{E}+07$

$5.9459 \mathrm{E}+07$

$5.9166 \mathrm{E}+07$

$5.0115 E+07$

$4.9632 \mathrm{E}+07$

5.5764007

$5.6555 \mathrm{~B}+07$

$6.0239 \mathrm{E}+07$

$6.3605 E+07$

$6.3343 \mathrm{E}+07$

$4.8250 \mathrm{E}+07$

$3.9350 \mathrm{E}+07$

$3.1162 \mathrm{E}+07$

$2.9036 \mathrm{E} \times 07$

$3.091 .5 \mathrm{E}+07$

2. $5825 \mathrm{E}+07$

$1.70658+07$

$1.6117 \mathrm{E}+0)$

$8.2182 \mathrm{E}+06$

$6.4077 \mathrm{E}+06$

$3.4375 \mathrm{E}+06$

$2.9200 \mathrm{E}+06$

1. $8658 \mathrm{E}+06$

4. $7524 \mathrm{E}+05$

$3.04732+05$ 


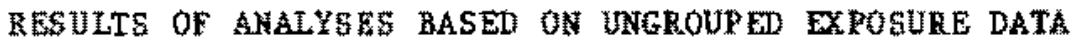

ALL CAUSES $(0-999)$

NURBER OF DEATHS

ODSERVED MEAN

\# 2313

EXPECTED MEAN

$=1.667768 \mathrm{E}+00$

TREND TEST STATISTIC

$=1.726937 \mathrm{E}+00$

$=-7.497727 \mathrm{E}-01$

UNADJUSTED ONE-TAILED P-VALUT $=7.732343 \mathrm{E}-01$

ADJUSTED ONE-TALED P-VAIUE

TOWAL VARIANCE

$-7.712489 \mathrm{E}-01$

$=3.331769 \mathrm{E}+04$

NO CERTIFICATE (0)

NUMEER OF DEATHS

OBSERVEO MEAN

$=65$

EXPECTED MEAN

$=2.180 .308 \mathrm{E}+00$

$=2.579965 \mathrm{E}+00$

TREND TEST STATHSTIC

$=-6.311903 \mathrm{E}-01$

UNADJUSTED ONE-TAILED PWVALUE

$=7.359831 \mathrm{E}-\mathrm{E}$

ADJUSTED ONE-TATLED P-VALUE

TOTAL VARIAWCE

$=7.201983 \mathrm{E}-\mathrm{-01}$

$=1.693 \mathrm{~B} 72 \mathrm{E}+03$

ALL NON-CANCERS $(1-139,210-999)$

NUMB ER OF DEATHS

$=\quad 1767$

OUSERVED MEAN

EXPECTED MIAN

TREND TEST STATISTIC

$=1.626284 \mathrm{E}+00$

$=1.663149 \mathrm{E}+00$

$=-4.209799 \mathrm{E}-0 \mathrm{~d}$

UNADJUSTED ONE-'TAILED P-VALUE

ADJUSTED ONE-TAILED P-VALUE

TOTAL. VARIANCE

$=6.631017 \mathrm{E}-01$

$=6.578649 \mathrm{E}-01$

$=2.394278 \mathrm{E}+04$

ALL CANCERS $(140-209)$

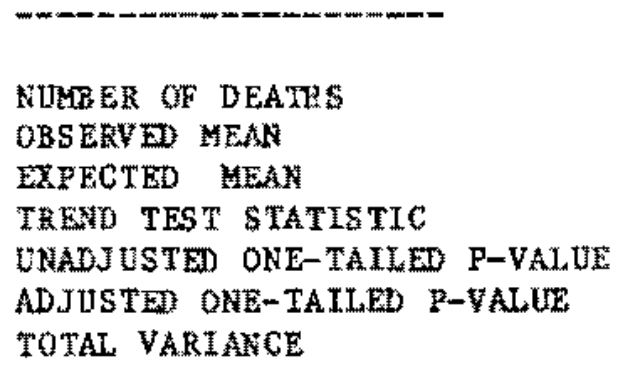

$=481$

$=1.750895 \mathrm{E}+00$

$=1.846005 \mathrm{E}+00$

$=-5.219822 \mathrm{E} m 01$

$=6.991166 \mathrm{E}-01$

$=6.909091 \mathrm{E}-01$

$=7.681221 \mathrm{E}+03$ 
RESULTS OF ANALYSES BASED ON UNGROUPED FXPOSURE DATA

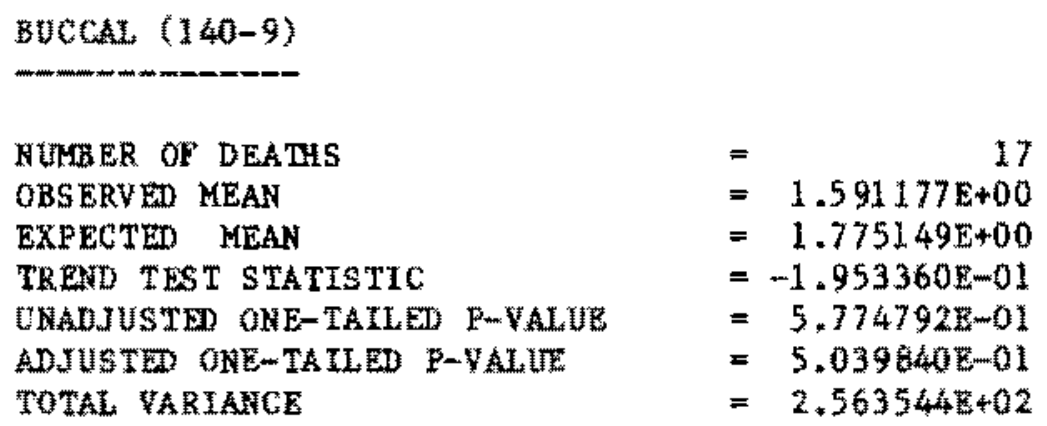

STOMACH (151)

\begin{tabular}{|c|c|}
\hline \multicolumn{2}{|l|}{ NLDER OF DEATHS } \\
\hline OBSERVED MEAN & $2.533478 \mathrm{E}+00$ \\
\hline 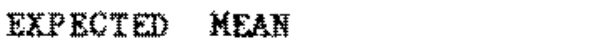 & $1.822402 \mathrm{E}+00$ \\
\hline TREND TES STETISTIC & $8.8003695-02$ \\
\hline UNADJUSTED ONE-TEILED E-VALUE & $1.894507 E-01$ \\
\hline ADJUSTED ONE-TAILED P-VALUE & $1.829632 \mathrm{E}-01$ \\
\hline TOTAL, VARTANCE & $3.453717 \mathrm{E}+02$ \\
\hline
\end{tabular}

LARGE INTESTINE (153)

NUMEER OF DEATHS

OBSERVED HEAE

EXPETTE MENAN

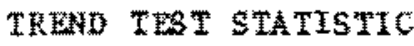

URADJUSTED ONE-TALLE PWVALUE

ADJUSTED ONE-TAILED P-VALUE

TOTAL VARTANCE
$=51$

$=1.046863 \mathrm{E}+00$

$=1.567400 \mathrm{E}+00$

$=-1.026820 \mathrm{E}+00$

$=8.46860401$

$=8.499640 \mathrm{E}-01$

$=6.686595 \mathrm{E}+02$ 
RECTUK (154)

NUMBER OE DEATHS

OBSERVED MEAN

EXPECTED MEAN

TREDD TEST STATISTIC

UNADJUSTED OWE-TAILET T-VALUE

ADIUSTED OUE-TALED R-VALUE

TOMAL VARTANCE
" 16

$=1.135000 \mathrm{E}+00$

$=1.635225+00$

$=-5.686434 \mathrm{E}-01$

$=7.151523 \mathrm{E}-01$

$=6.60581 .4 \mathrm{E}-01$

$=2.396849 \mathrm{E}+02$

PANCREAS (157)

NUKSER OF DEATHS

OBSERVED HEAN

EXPECTED MEAN

TREAD TST STATHSTC

UNADJUSTED ONE-TAILEO P-VALUE

ADJUSTED ONEWTALED P-YALUE

TOTAL, VARIARCE
\# 34

$=2.053824 \mathrm{E}+00$

$=1.547341 \mathrm{E}+00$

$=8.640711 \mathrm{E}-01$

$=1.938459 \mathrm{E}-01$

$=1.864136 \mathrm{E}-01$

$=3.971810 \mathrm{E}+02$

ALI OTHER CANCERS $(160-1,163,170-3,166-7,190,193-9)$

\begin{tabular}{|c|c|}
\hline NUYB ER OF DEATHS & \\
\hline OBSERVEO MEAN & $1.487308 \mathrm{E}+00$ \\
\hline EXPQETED MEAN & $=1.861886 \mathrm{E}+00$ \\
\hline TREND TEST STATISTIC & $=-6.813782 \mathrm{E}-01$ \\
\hline UNADJUSTED ONE-TAILED P-VALUE & $=7.521191 \mathrm{E}-01$ \\
\hline ADJUSTED ONE-TAILED P-VALEE & $7.3391595-01$ \\
\hline TOTAL VARIANCE & 8.171771002 \\
\hline LUNG $(162)$ & \\
\hline NESBER OT DEATHS & 152 \\
\hline OBSERYED MEAN & $2.222500 \mathrm{E}+00$ \\
\hline EXPECTED MEAN & $2.1641482+00$ \\
\hline TER TEST THATSTIC & $=1.595358 \mathrm{E}-01$ \\
\hline UNADJUSTED ONE-TALLED P-VALUE & $=4.365759 \mathrm{E}-01$ \\
\hline ADJUSTED ONE-TAILE P-VALUE & $=4.174632 \mathrm{E}-01$ \\
\hline "WOTAL VARLAMCE & $=3.090926 \mathrm{E}+03$ \\
\hline
\end{tabular}


BEAST $(174)$

NUMBER OF DEATHS

OBSERYED MEAN

EXPECTED MEAN

TREAD TEST STATISTIC

UWADUUSTI ONE-TAILED P-VALUE

ADJUSTED ONE-TAILED P-VALUE

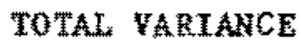

PosTate (185)

NUMBER OF DEATHS

OBSERVED MEAN

EXEECT MEAN

TREND TEST STATISTIC

UNADUUSTED ONE-TAILIS PALUE

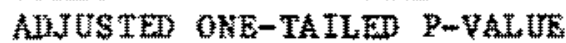

TOTAL VARIAHCE

BLADDER \& URTNARY (188-9)

NUMB ER OF DEATHS

OBSERV WED WEA

EXPECTED HEAN

TREND T⿱艹⿻三丨口

UNADJUST ONE-TAILED P-VALUE

NDJUSTED ONE-TAYLE P-YALET

TOTAL VARTANCE

BRAIN (191-2)

WUTER ON DEATHS

OBS

EXPECTED MEA

TRED TES STATSTIC

UNADUUSTE ONE-TANLED P-VALUE

ADJUSTEO ONE-TAILED P-YALUE

TOTAL VARTANCE
$=1$

$=0.000000 \mathrm{E}+00$

$=9.876519 \mathrm{E}-01$

$=-5.543386 \mathrm{E}-01$

$=7.102805 \mathrm{E}-01$

$=4.353584 \mathrm{E}-01$

$=3.174370 \mathrm{E}+00$

$=39$

$=1.269487 \mathrm{E}+00$

$=1.904819 \mathrm{E}+00$

$=-9.310567 \mathrm{E}-01$

$=8.240188 \mathrm{E}-01$

$=8.191673 \mathrm{E}-01$

$=7.082361 \mathrm{E}+02$

$=\quad 17$

$=1.262941 \mathrm{E}+00$

$=1.362512 \mathrm{E}+00$

$=-1.314525 \mathrm{E}-01$

$=5.52338 \mathrm{~g}-01$

$=4.727300 \mathrm{E}-0 \mathrm{~L}$

$=1.658139 \mathrm{E} * 02$
$=15$

$=9,253334 \mathrm{E}-101$

$=1.740059 \mathrm{E}+00$

$=-9.152 \% 1 \mathrm{E}-01$

$=8.199121 \mathrm{E}-01$

$=8.126065 \mathrm{E}-0 \mathrm{l}$

$=1,782848 \mathrm{E}+02$ 
LYMFHOSARCOMA (200)

\begin{tabular}{|c|c|}
\hline NUMBER OF DEATHS & \\
\hline OBSERVED MEAN & $1.143846 \mathrm{E}+00$ \\
\hline EXPECTED MEAN & $1.694287 \mathrm{E} \div 00$ \\
\hline TREND TEST STATTSTIC & $=-5.482950 \mathrm{E}-01$ \\
\hline DNADJUETED ONE-TATLED P-VALUE & $=7.082106 \mathrm{E}-0$ \\
\hline ADJUSTED OHE-TAILED P-VALUE & $6.469836 \mathrm{E}-0$ \\
\hline TOTAL VARI筑CE & $1,702638 \mathrm{E}+0$ \\
\hline
\end{tabular}

HODWKIN'S DISEASE (201)

\begin{tabular}{|c|c|}
\hline NUMBER OCOFATHS & \\
\hline OBSERVED MEAN & $4.433334 \mathrm{E}-01$ \\
\hline EXPECTED BEAN & $1.365158 \mathrm{E}+00$ \\
\hline TREND IEST STATLSTIC & $=-8.030005 \mathrm{Em} 01$ \\
\hline UNAOJUSTED ONE-TEALE P-VALUE & $41 \mathrm{E}-01$ \\
\hline ADJUSTED ONE-TALLE PMVLUE & $7.690995 \mathrm{E}-01$ \\
\hline TOFAI YARIANCE & $4.744251 \mathrm{E}+01$ \\
\hline
\end{tabular}

OTERR LYMPHATIC NEOPLASMS $(202,208-9)$

NUTEER OR DEATHS

OBSERYED MEAN

EXPECTED MEAN

TEEND TW STATISTTC

VNADJUSTED ONE-TAILED E-VALUS

ADJUESTE ONE-TALLED P-VALIE

TOTAL YARIANCE

MULTELW WELOMA (20.3)

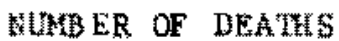

OBS ERVE MEAN

EXPECTED MEAN

TREND TEST STATIS TIC

UNADJUSTE ONE-TAILUE PW YALUE

ADJUSTED ONE-TATLED P-VALUE

TUTAL VARIANCE
$=6$

$=2.683333 \mathrm{E}-01$

$=1.772424 \mathrm{E}+00$

$=-9.822353 \mathrm{E}-01$

$=8.369419 \mathrm{E}-01$

$=8.381217 \mathrm{E}-01$

$=8.441 .49 \mathrm{E}+01$

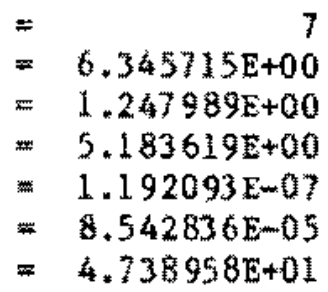


OTHES LEVERTA $(204,206-7)$

NUMB ER OF DEATHS

OBSERVED MEAN

EXPECTED MEAN

TREND TEST STATISTIC

UNADJUSTED ONE-TALEED P-YALUE

ADJUSTED ONEMTAILED P-VALUE

TOTAL VARIANCE

MYELOTD LEUKEMIA $(205)$

$$
\begin{aligned}
& = \\
& =1.866667 \mathrm{E}-01 \\
& =1.391125 \mathrm{E}+00 \\
& =-9.589486 \mathrm{E}-01 \\
& =8.311401 \mathrm{E}-01 \\
& =8.293951 \mathrm{E}-01 \\
& =5.679305 \mathrm{E}+01
\end{aligned}
$$

M-

NUMBER OF DEATHS

OBSERYED MEAN

EXPECTED KEAN

TREND TEST STATISTIC

UNADUYSTE ONE-TAILED PNALVE

ADUUS

TOTAL VARTANCE

$$
\begin{array}{lr}
= & 8 \\
= & 2.743750 \mathrm{E}+00 \\
= & 2.745691 \mathrm{E}+00 \\
= & -1.066683 \mathrm{E}-03 \\
= & 5.004264 \mathrm{E}-01 \\
= & 4.267560 \mathrm{E}-01 \\
= & 2.119388 \mathrm{E}+0 .
\end{array}
$$

INE ECTLOS $(1-136)$

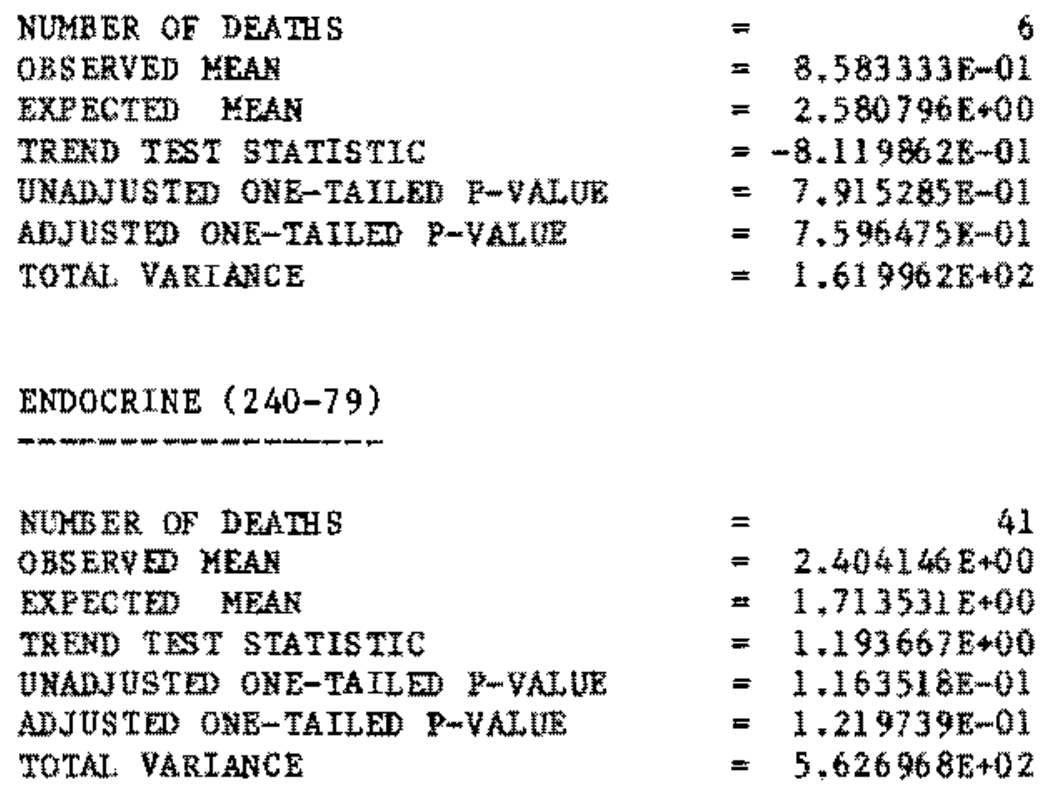

$$
\begin{aligned}
& = \\
& =8.589333 \mathrm{E}-01 \\
& =2.580796 \mathrm{E}-00 \\
& =-8.119802 \mathrm{E}-01 \\
& =7.915285 \mathrm{E}-01 \\
& =7.596 .55 \mathrm{E}-01 \\
& =1.619962 \mathrm{E}+02
\end{aligned}
$$

$$
\begin{array}{lr}
= & 41 \\
= & 2.404446 \mathrm{E}+00 \\
= & 1.713531 \mathrm{E}+00 \\
= & 1.193667500 \\
= & 1.163518 \mathrm{E}-01 \\
= & 1.219739 \mathrm{E}-01 \\
= & 5.626968 \mathrm{E}+02
\end{array}
$$


RESULTS OF ANALUSES BASED ON UNGROUPED EXPOSURE DATA

BLOOD $(280-9)$

NUMBER OF DEATHS

OBSERVED MEAN

EXPECTED MEAN

TREND TEST STATISTIC

UNADJUSTED ONE-TAILED P-VALUE ADJUSTED ONE-TAILED P-YALUE

TOTAL VARANCE

$\begin{array}{rr}= & 3 \\ = & 5.253334 \mathrm{E}+00 \\ = & 2.196561 \mathrm{E}+00 \\ = & 1.168814 \mathrm{E}+00 \\ = & 1.212894 \mathrm{E}-01 \\ & 1.211008 \mathrm{E}-01 \\ = & 6.155709 \mathrm{E}+01\end{array}$

MEXTaL (290-315)

NUMBER OT DEATHS

OBSERVED HEN

DXPECTED MEAN

TREND TEST STATISTIC

UNADUUSTED OKE-TALED P-VALUE

ADVUSTED ONE-TAILED P-VALUE

TOTAL VARIANCE

NERVOUS SENSORY (320.89)
$=12$

$=3,934167 \mathrm{E}+00$

$=2.027063 \mathrm{E}+00$

$=1.505560 \mathrm{E}+00$

$=6.610996 \mathrm{E}-02$

$=8.026239 \mathrm{E}-02$

$=2.310549 \mathrm{E}+02$
NUMBER OF DEATHS

OBSERY ED MEAN

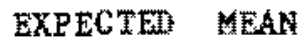

TREND TEST STATISTIC

UNADJUSTED ONE-TAILED P-VALUE

ADJUSTED ONE-TAILED P-VALUE

TOMAL VARIANCE

CIRCULATORY $(390-458)$
$=17$

$=3.829412 \mathrm{E}+00$

$=2.009433 \mathrm{E}+00$

$=1.747004 \mathrm{E}+00$

$=4.032487 \mathrm{E}-02$

$=5.71 .9397 \mathrm{E}-02$

$=3.136483 \mathrm{E}+02$

$=\quad 1263$

$=1.600490 \mathrm{E}+00$

$=1.668530 \mathrm{E}+00$

$=-6.481745 \mathrm{E}-01$

$=7.415028 \mathrm{E}-01$

$=7.375623 \mathrm{E}-01$

$=1.731962 \mathrm{E}+04$ 
RESUL; $S$ OF ANALYSES BASED ON UNGROUPEO EXPOSURE DATA

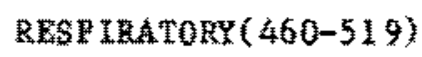

NUMEER OF DEATHS

OBSERVED MTAN

EXPECTED MEAN

TREND TEST STATISTIC

UNADUVSTED ONE-TAILED R-VALVE

ADJUSTED ORE-TATRED P-VALUE

TOTAL VARIANCE

$=122$

$=1.727459 \mathrm{E}+00$

$=1.548601 \mathrm{E}+00$

$=5.602764 \mathrm{E}-01$

$=2.876925 \mathrm{E}-0 \mathrm{l}$

$=2.735422 \mathrm{E}-0.1$

$=1.516820 \mathrm{E}+03$

DTGESTVE (520-77)

NUMBER OF DEATHS

OBSERVED MEAN

EXPECTED MEAN

TREND TEST STATISTIC

UNADUUSTED ONE-TAILED F-VALU ADJUSTE ONE-TAIIED P-YALIE

TOTALE VARIANCE

$=95$

$=1.648948 \mathrm{E}+00$

$=1.797532 \mathrm{E}+00$

$=-3.799962 \mathrm{E}-0 \mathrm{I}$

$=6.480243 \mathrm{E}-01$

$=6.253619 \mathrm{E}-01$

$=1.379301 \mathrm{E}+03$

RESTDUAL $(210-39,580-799)$

NLELBER OF DEATHS

$=43$

ONSERV WE WAN

EXPECTED MEAN

TREND TEST STATISTIC

$=9.699536 \mathrm{E}-01$

$=1.514855 \mathrm{E}+00$

UNADUUSTE ONE-TAILED F-VALUE

ADJUSTE ONE-TAILED P-VALUE

TOTAL, VARIANCE

$=-1.039032 \mathrm{E}+00$

$=8.505431 \mathrm{E}-0 \mathrm{~L}$

$=8.53256 \mathrm{E} \mathrm{E}-01$

$=5.197897 \mathrm{E}+02$

EXTERNAL（800-999)

\begin{tabular}{|c|c|}
\hline NUMUER OF DEATHS & 165 \\
\hline OBSERVED MEAN & 1.278485600 \\
\hline EXIX & $1.550225 \mathrm{E}+00$ \\
\hline ThEND TES STATISTIC & $=-1.0352652600$ \\
\hline UNADUUSTE ONE-TATLE SMALUE & $=8.496652 \mathrm{E}-0.1$ \\
\hline ADJUSTED ONE-TAILED P-VALUE & $8.509423 \mathrm{E}-01$ \\
\hline TOWAL VARIANCE & $=1.8757445+03$ \\
\hline
\end{tabular}


REGULTS OF ANALYBS BASED ON GROUPED EXPOSURE DAIA

ALL CAUSES $(0-999)$

\begin{tabular}{|c|c|c|c|c|c|}
\hline \multicolumn{2}{|l|}{ NUMBER OF DEATHS } & \multicolumn{4}{|c|}{2313} \\
\hline \multicolumn{2}{|l|}{ OBSERVED WEAN SCORE } & \multicolumn{4}{|c|}{$=1.663160 \mathrm{E} * 00$} \\
\hline \multicolumn{2}{|l|}{ EXEECTED NEAN SCORE } & \multicolumn{4}{|c|}{$=1.701086 \mathrm{E}+00$} \\
\hline \multicolumn{2}{|l|}{ TREND TEST STAFTIS } & \multicolumn{4}{|c|}{$=-5.032300 \mathrm{E}-01$} \\
\hline UNADUYSTED ONE-算ALED & $\mathrm{P}-\mathrm{VAL}$ 政 & $=$ & $6.925668 \mathrm{E}-01$ & & \\
\hline \multicolumn{5}{|c|}{ TOTAZ YARTANCE } & \\
\hline \multicolumn{6}{|c|}{ CHI-SQQUAE TEST FOR HOHOGGNEITY } \\
\hline OBSERVED FREQUENCTES & $1,922000 \mathrm{E}+$ & +03 & $2,110000 \mathrm{E}+02$ & $1.260000 \mathrm{E}+02$ & $3.400000 \mathrm{E}+01$ \\
\hline EXPECTED FREOUUENCIES & $1,916978 \mathrm{E}$ & +03 & $2.139498 \mathrm{E}+02$ & $1.233539 \mathrm{E}+02$ & $5.872012 \mathrm{E}+01$ \\
\hline 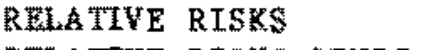 & $1.017156 \mathrm{E}+$ & +00 & $9.8432342-01$ & $1.0235735+00$ & $9.144483 E-01$ \\
\hline RELATIVE RISKS LANDS & $9.073025 \mathrm{E}$ & -01 & $8.524367 \mathrm{E}-01$ & $8.5229 .41 \mathrm{E}-01$ & $6.943008 E-01$ \\
\hline REATIVE RISKS UDNDS & $1.140310 \mathrm{E}$ & +60 & $1.136615 E+00$ & $1.229272 \mathrm{E}+00$ & $1.2044008+00$ \\
\hline 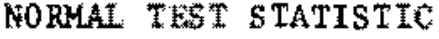 & $2.917196 \mathrm{E}$ & & $-2.152814 \mathrm{E}-01$ & $2.493765 \mathrm{E}-01$ & $-6.364610 \mathrm{~s}-01$ \\
\hline
\end{tabular}

NO CERTIF LCATE (0)

\begin{tabular}{|c|c|c|c|c|}
\hline NUMBER OF DEATHS & & & & \\
\hline OBS ERYED MEAN SCORE & & $2.256118 \mathrm{E}+00$ & & \\
\hline EXPECTED MEAN SCOQRE & $=$ & $=2.4150330+00$ & & \\
\hline TREND TEST STATISTYC & & $-2.757545 \mathrm{E}-01$ & & \\
\hline UNADJUSTEE ONE-TAILEW & POVALUE & $6.086594 \mathrm{E}-0 \mathrm{D}$ & & \\
\hline ADJUSTED ONE-TAILED & $P-V A D$ AE & $5.856334 \mathrm{E}-01$ & & \\
\hline TOTAL VARIANCE & $=$ & $1.403183 \mathrm{E}+03$ & & \\
\hline CUL-SQUARE TEST TOR H & MOGENEITH & $2.282088 \mathrm{E}+00$ & & \\
\hline OASERVED FREQUENCIES & $5.300000 \mathrm{E}+01$ & $4.000000 \mathrm{E} \div 00$ & $5.000000 \mathrm{E}+00$ & $3.000000 \mathrm{E}+00$ \\
\hline EXPECTES SREOUENCIES & $4.903926 \mathrm{E}+01$ & $7.780671 \mathrm{E}+00$ & $5.245467 \mathrm{E}+00$ & $2.934611 \mathrm{~g}+00$ \\
\hline RELATTVE RES & $1.461451 \mathrm{E}+0 \mathrm{C}$ & $4.692206 \mathrm{E}-01$ & $9.4831095-01$ & $1.023983 \mathrm{E}+00$ \\
\hline RELATIVE BISKS LBNDS & $7.862435 \mathrm{E}-01$ & $1.708529 \mathrm{E}-01$ & $3.800814 E-01$ & $3.173085 \mathrm{E}-01$ \\
\hline DELATIVE RTSKS UDNDS & $2.716512 \mathrm{E}+00$ & $1.288641 \mathrm{E}+00$ & $2.366055 \mathrm{E}+000$ & $3.304484 \mathrm{E}+00$ \\
\hline NORUAL TEST STATISTIC & $1.1996462+00$ & $0-1.460020 \mathrm{~B}+00$ & $-1.137736 \mathrm{E}-01$ & $3.964869 \mathrm{E}-02$ \\
\hline
\end{tabular}


ALL NON-CANCERS $(1-139,210-999)$

\begin{tabular}{|c|c|}
\hline NLMEER OF DEATHS & 1767 \\
\hline OBSERUED MEAN SCORE & $1.604339 \mathrm{E}+00$ \\
\hline EXPECTED MEAN SCORE & $1.647659 \mathrm{E}+00$ \\
\hline 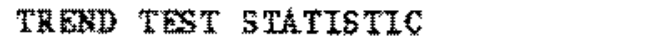 & $=-5.146660 \mathrm{z}-01$ \\
\hline UNADUUSTE ONE-TAILED P-VALUE & $=6.965694 \mathrm{k}-01$ \\
\hline ADJUSTED ONE-TAIEED E-VALUE & $6.9243995-01$ \\
\hline $\begin{array}{l}\text { TOTAL VARLAKCE } \\
\text { CHI-SQUARE TEST FOR HOKOGENET } W\end{array}$ & $\begin{array}{l}=2.212082004 \\
=4.09810801\end{array}$ \\
\hline
\end{tabular}

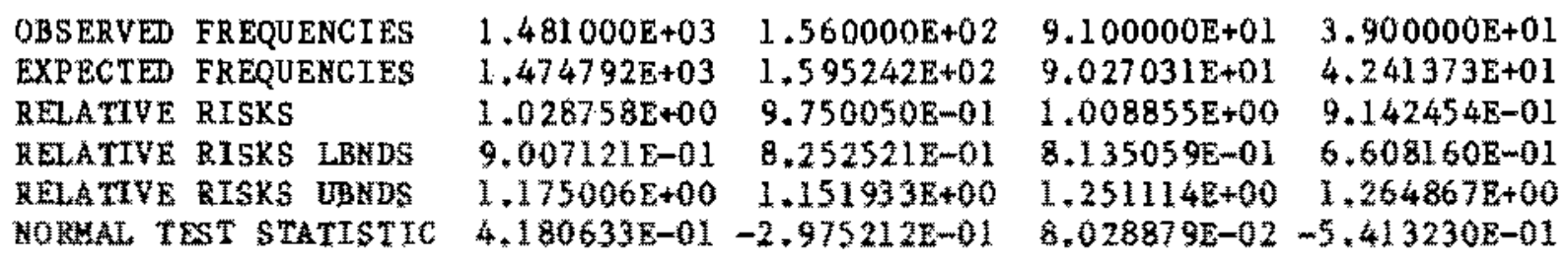

ALI CANCERS (140-209)

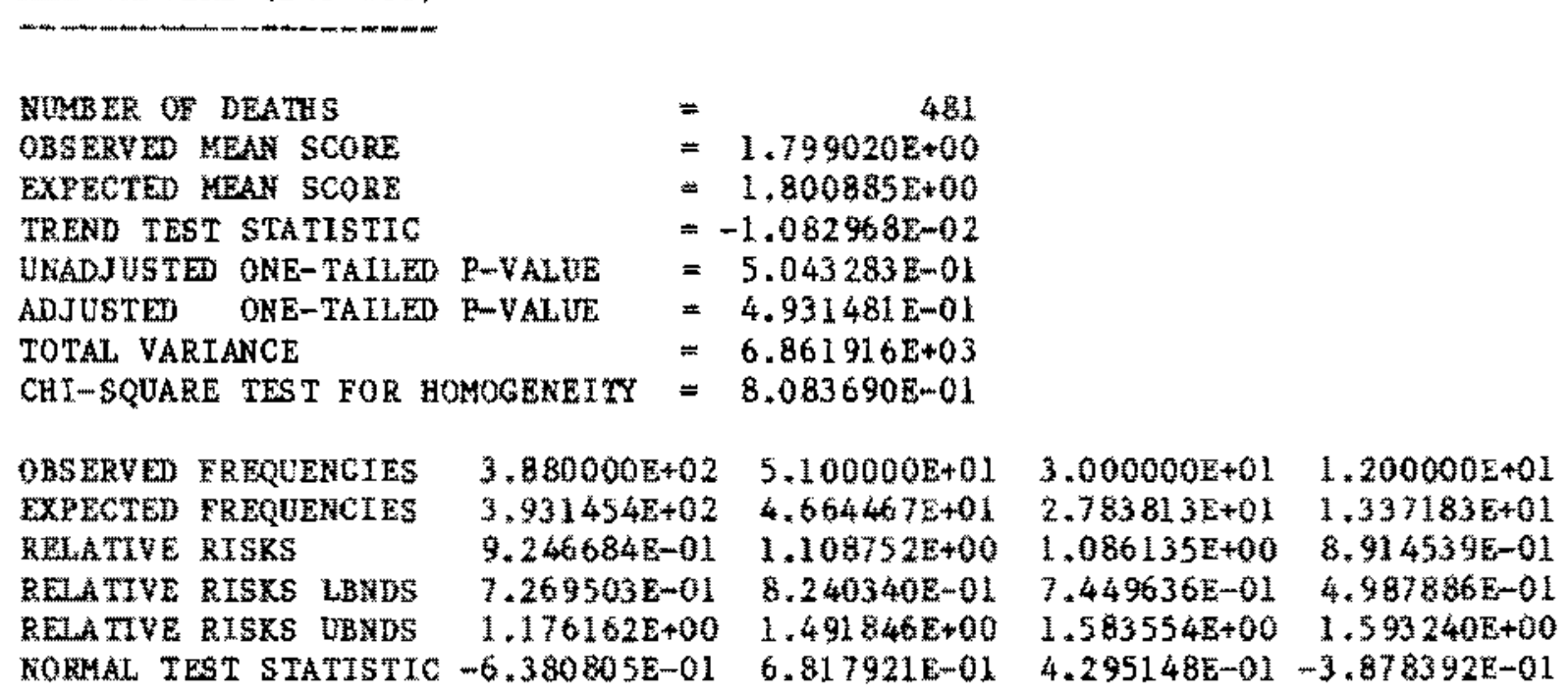


BUCEAL $(140-9)$

NUMBER OF DEATHS

OBSERY ED MEAN SCORE

EXPECTED MEAN SCORE

TREND TEST STATISTIC

UNADJUSTE ONE-TALLED P-VALUE

ADNUSTED ONE-TALLED P-VALUE

TOTAL VARIANCE

CHI-SQUARE TEST FOR HOYOGENET T
$=$

$=1.584050 \mathrm{E}+00$

$=1.698320 \mathrm{E} \div 00$

$-1.307275 \mathrm{E}-01$

$=5.520521 \mathrm{E}-01$

$=4.870790 \mathrm{E}-01$

$=2.208169 \mathrm{E}+02$

$=1.941449 \mathrm{E}+00$
OBSERVED FREUENCIES $1,400000 \mathrm{~F}+01 \quad 1.000000 \mathrm{E}+00$

EXPECTED FREQUENCIES $1.405674 \mathrm{E} * 01 \quad 1.604907 \mathrm{E}+00$

RELATIVE RISRS

RELATIVE RISRS LBENDS

RELATTVE RISKS UANDS

$9.729527 \mathrm{E}-01 \quad 5.889165 \mathrm{E}-01$

$2.381258 \mathrm{E}-01 \quad 7.673796 \mathrm{E}-02$

$3.575365 \mathrm{E}+00 \quad 4.519571 \mathrm{E}+00$

NOML TEST STATISTIC $-3.818225 \mathrm{E}-02-5.092345 \mathrm{E}-01$
$2.000000 \mathrm{E}+00$

$9.165787 \mathrm{E}-01$

$2.500902 \mathrm{E}+00$

$5.487171 \mathrm{E}-01$

$1.139542 \mathrm{E}+01$

$1.134473 E+00$
$0.000000 \mathrm{E}+00$

$4.217739 \mathrm{E}-01$

$0.000000 \mathrm{E}+00$

$0.000000 \mathrm{E}+00$

$0.000000 \mathrm{E}+00$

$-6.6976072-01$

OTHER DIGESTIVE $(150,152,154-6,158-9)$

NUNB ER OF DEATHS

OBSERVED HEAN SCOKE

EXPECTED MEAN SCORE

TREND TEST STATSTIC

UNADJUSTED ONE-TAILD P-VALUE

ADJUSTED ONE TAILED P-VALUE

TOTAL VARQ

CHT-SQUARE TEST FOR HOMOEENEITY
$=18$

$=1.682847 \mathrm{E}+00$

$=1.473972 \mathrm{E}+00$

$=2.776402 \mathrm{E}-01$

$=3.906171 \mathrm{E}-01$

$=3.383525 E-01$

$-1.833808 \mathrm{E}+02$

$=\quad 3.993554 \mathrm{E}+00$

\begin{tabular}{|c|c|c|c|c|c|}
\hline & & & & & \\
\hline & UENGTES & & $\div 00$ & $8.666132 \mathrm{E}-01$ & \\
\hline & RISKS & & $\$ 00$ & & \\
\hline $\mathbf{E}$ & 民SKS LBHDE & & & & \\
\hline & & & & & \\
\hline & & & $41 E+00$ & 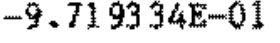 & \\
\hline
\end{tabular}


STOHACH (151)

NUABER OF DEATHS

OBSERVED MEAN SCORE

EXPECTED MEAN SCORE

TAEND TEST STATISTIC

UNADJUSTLE ONE-TALLED POLLUE

ADJUSTED ONEWTALED F-VALE

TOZAL VARIANOE

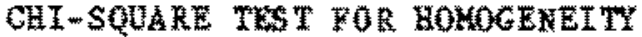

$=\quad 23$

$=2.930220 \mathrm{E}+00$

$=1.841094 \mathrm{E}+00$

- 1.346813E+00

$=8.905315 \mathrm{E}-02$

$=1.002516 \mathrm{Em}$

$=3.459373 \mathrm{E}+02$

$=2,802805 \mathrm{E}+00$

\begin{tabular}{|c|c|c|c|c|c|}
\hline 3S BRY & 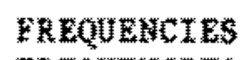 & $1.800000 \mathrm{E}+01$ & $2.000000 \mathrm{E}+00$ & $1.000000 \mathrm{E}+00$ & \\
\hline$T$ & 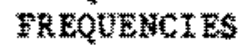 & & & & \\
\hline & 紫堇SKS & & & & \\
\hline ELATIV & RISKS & & & & \\
\hline QLATIVE & R.SKS UBNDS & $0125 E+$ & $84408+00$ & 00 & $629 \mathrm{E}+0$ \\
\hline ORMAL T & 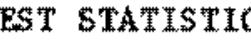 & & & & $61082 \mathrm{E}+$ \\
\hline
\end{tabular}

LARGE INTESTINE (153)

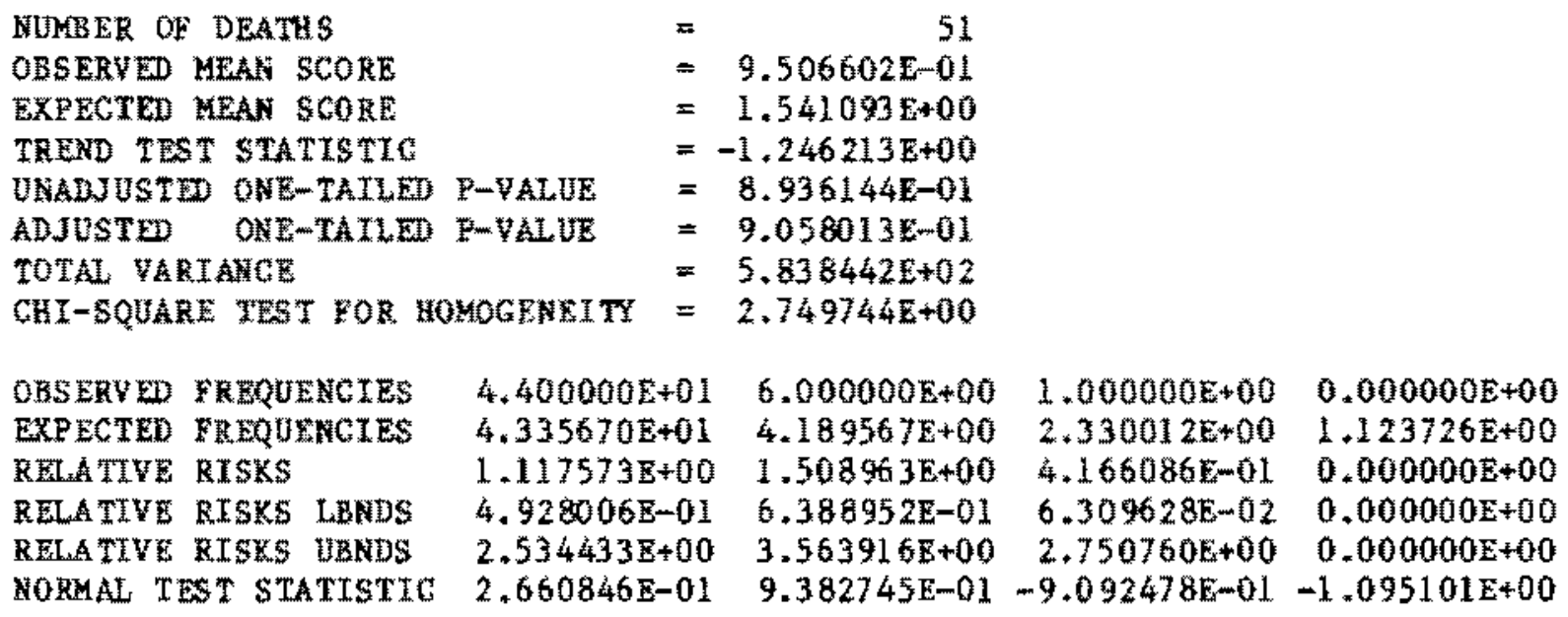


RESULAS OF ANALYSES BASED OH GROUPED EXPOSURE DATA

RECTIN (154)

NUMBER OF DEATHS

OBSERVD HEAN SCORE

EXECETE MEAN SCORE

TREND TEST STATISTIC

UNADUUSTED ONE-TALLED R-VALUE

ADNUSTED ONE-TAILED PMVALU:

TOTAL VARIANCE

CHI-SQUARE TEST EOR HOHOGENEITY
$=$

$=1.151781 \mathrm{E}+00$

$=1.667137 \mathrm{E}+00$

$=-5.73350 \mathrm{5}-01$

$=7.167573 \mathrm{E}-01$

$=6.689884 \mathrm{E}-01$

$=2.068080 \mathrm{E} 402$

$=5.741913 \mathrm{E}-01$

\begin{tabular}{|c|c|c|c|c|c|}
\hline & FREQ & 1.40 & $E+00$ & & \\
\hline KECTE & UENCI. & & & & \\
\hline GATIVE & & & & & \\
\hline & & & & & \\
\hline & & & & & $0008+00$ \\
\hline & & & & $2.077785 \mathrm{E}-01$ & 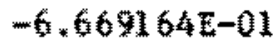 \\
\hline
\end{tabular}

PANCREAS (157)

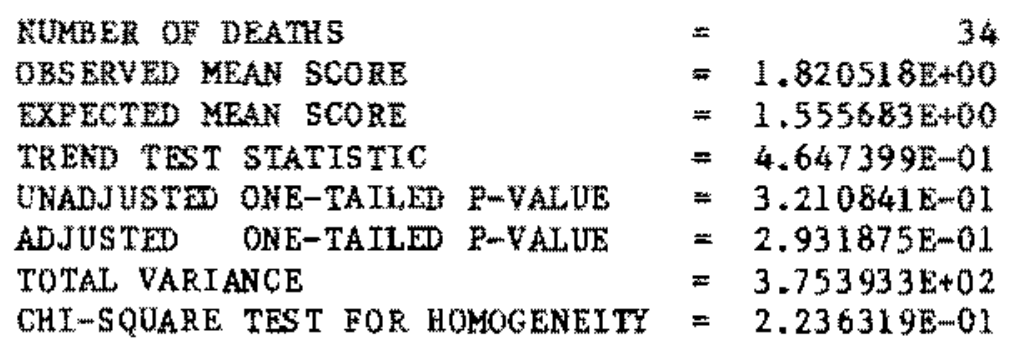

\begin{tabular}{|c|c|c|c|c|c|}
\hline & & $800000 \mathrm{E}+01$ & $100 z+00$ & $0 \mathrm{E}+00$ & \\
\hline & FREC & & & & \\
\hline & & & & & \\
\hline & UISTS & & & & \\
\hline & & & & & 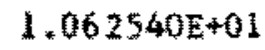 \\
\hline RMAI II & & & & $.516951 \mathrm{E}-01$ & $3.819040 \mathrm{E}$ \\
\hline
\end{tabular}


ALL OMHER CANCERS $(160-1,163,170 m, 186-7,190,193-9)$

NUMB ER OF DEATHS

OBSERVED MEAN SCORE

EXPECTED MEAL SCORE

THENI TT STATISTIG

UNADUUSTEO ONE-TALED P-VALUE

ADJUSTED ONE-TALLED PWVAUE

TOTAL VARIANCE

CHI-SQQUARE TEST FOR HONOGENETTY
$=52$

$=1.613249 \mathrm{E}+00$

$=1.823216 \mathrm{E} 400$

$=-4.0155248-01$

$=6.559854 \mathrm{E}-01$

$=6.270502 \mathrm{E}-01$

$=7.393069 \mathrm{E}+02$

$=1.635214 \mathrm{E}-01$
OASERVED FREQUENCIES

EXPECTED FREQUENCIES

RELATIVE RISKS

RELATIVE RISKS LBWDS

RELATTVE RISKS UBHDS

NORMAL, TEST STATISTIC
4. $300000 \mathrm{E}+01$

$4.221653 \mathrm{E}+01$

$1.120721 \mathrm{E}+00$

$5.18547 \mathrm{gE}-01$

$2.422181 \mathrm{E}+00$

2.484317500

$-6.88104 \mathrm{~g} g \mathrm{E}$
$3.000000 \mathrm{E}+00$

$3.233085 \mathrm{E}+00$

$9.209498 \mathrm{E}-01$

$2.812768 \mathrm{E}-01$

$3.015351 \mathrm{E}+00$

$-1.360847 \mathrm{E}-\mathrm{OI}$
$1.000000 \mathrm{E}+00$

$1.403783 \mathrm{E}+00$

$6.935410 \mathrm{E}-01$

$9.024 .472 \mathrm{E}-02$

$5.330001 \mathrm{E}+00$

LUNG (162)

NUNEE OF DEATS

OBSERVED MEAN SCORE EXPECTED WEAN SCORE

TRETO TEST STATISTIC

UNADJUSTE ONE-TAILED P-VALIUE ADJUSTED ONE-TAILED P-VALUE TOTAL, VARIANCE

CHI-SQUARE TEST FOR HOMOGENEITY
$=152$

$=2.324907 \mathrm{E}+00$

$=2.065086 \mathrm{E}+00$

$=7.663189 \mathrm{E}-01$

$=2.218139 \mathrm{E}-01$

- $2.169881 \mathrm{Em} 01$

$=2.655935 \mathrm{E}+03$

$=5.0275528+00$
OHSERVED FREOQUENCIES EXPECTE TREOUENCIES RELATE RISKS RELATIVE NISKS LBNDS

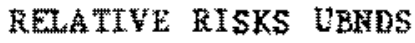
NORMAL TEST STATISTIC $-2.048474 E+00$
$1.100000 \mathrm{E}+02$ 1. $199385 \mathrm{E}+02$ $6.737381 \mathrm{E}-01$ 4.617318E-01 $3.830882 \mathrm{E}-01$

$2.300000 \mathrm{E}+01$ $1.666103 \mathrm{E}+01$ 1.47 $1953 \mathrm{E}+00$ $9.355650 \mathrm{E}-01$ $2.315867 \mathrm{E}+00$ $1.671345 \mathrm{E}+00$
$1.400000 \mathrm{E}+01$ $1.013538 \mathrm{E}+01$ $1.439758 \mathrm{E}+00$ $8.225650 \mathrm{E}-0 \mathrm{~L}$ $2.520045 \mathrm{E}+00$ $2.293548 \mathrm{E}+00$
$-1.634043 \mathrm{E}-01$

$5.000000 \mathrm{E}+00$ $5.365156 \mathrm{E}+00$ $9.272803 \mathrm{E}-01$ $3.7499008-01$ 
BREAST (174)

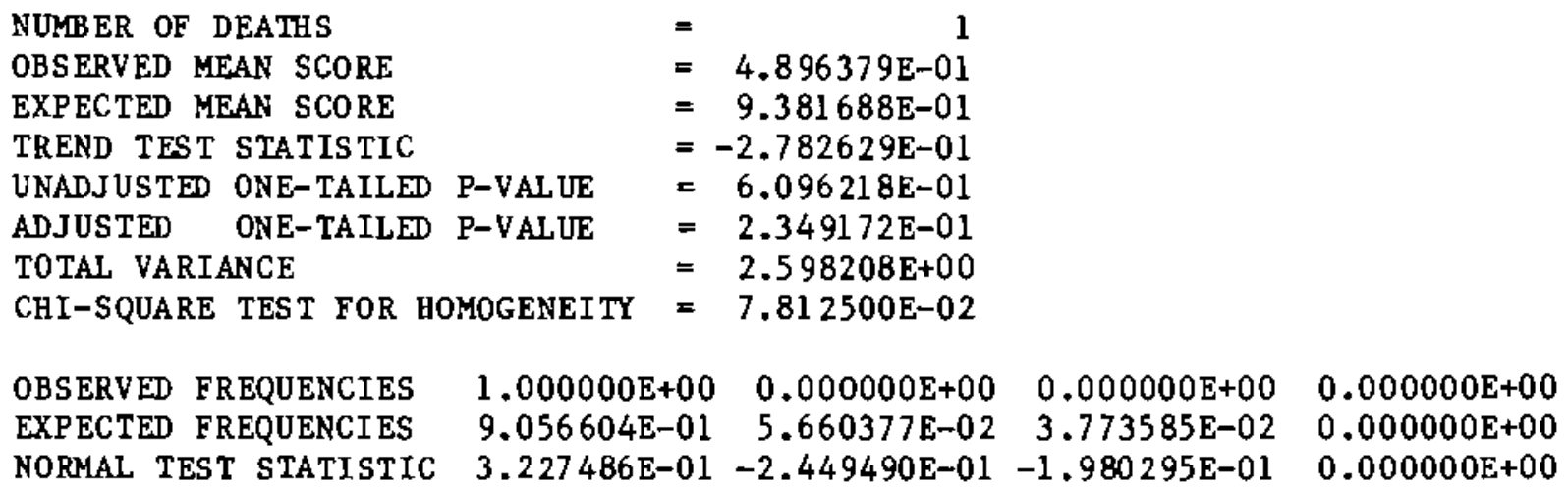

PROSTATE (185)

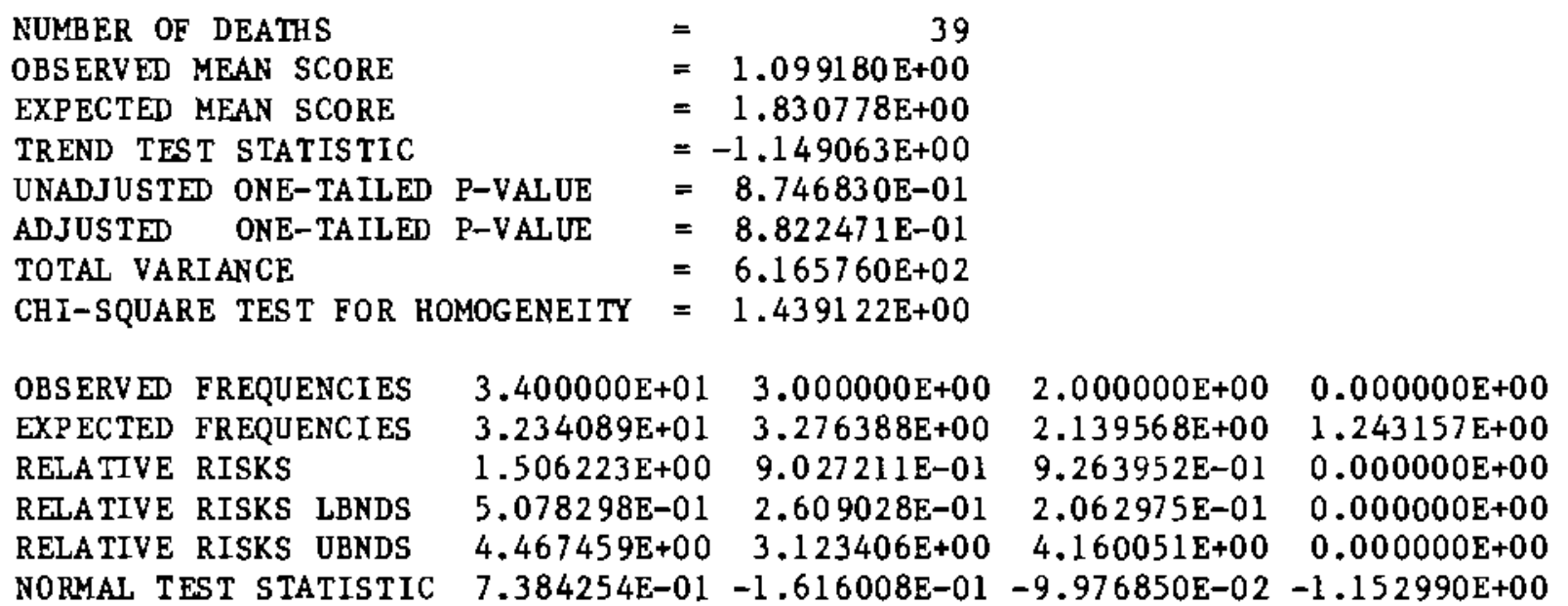


BLADDER \& URINARY (188-9)

$\begin{array}{llr}\text { NUMBER OF DEATHS } & = & 17 \\ \text { OBSERVED MEAN SCORE } & =1.112831 \mathrm{E}+00 \\ \text { EXPECTED MEAN SCORE } & =1.395479 \mathrm{E}+00 \\ \text { TREND TEST STATISTIC } & =-3.768041 \mathrm{E}-01 \\ \text { UNADJUSTED ONE-TAILED P-VALUE } & =6.468397 \mathrm{E}-01 \\ \text { ADJUSTED ONE-TAILED P-VALUE } & =5.754958 \mathrm{E}-01 \\ \text { TOTAL VARIANCE } & =1.626135 \mathrm{E}+02 \\ \text { CHI-SQUARE TEST FOR HOMOGENEITY } & =5.352263 \mathrm{E}-01\end{array}$

$\begin{array}{lrlllr}\text { OBSERVED FREQUENCIES } & 1.500000 \mathrm{E}+01 & 1.000000 \mathrm{E}+00 & 1.000000 \mathrm{E}+00 & 0.000000 \mathrm{E}+00 \\ \text { EXPECTED FREQUENCIES } & 1.467892 \mathrm{E}+01 & 1.329416 \mathrm{E}+00 & 6.931067 \mathrm{E}-01 & 2.985588 \mathrm{E}-01 \\ \text { RELATIVE RISKS } & 1.211519 \mathrm{E}+00 & 7.225786 \mathrm{E}-01 & 1.480194 \mathrm{E}+00 & 0.000000 \mathrm{E}+00 \\ \text { RELATIVE RISKS LBNDS } & 2.513332 \mathrm{E}-01 & 8.835857 \mathrm{E}-02 & 1.990417 \mathrm{E}-01 & 0.000000 \mathrm{E}+00 \\ \text { RELATIVE RISKS UBNDS } & 5.839973 \mathrm{E}+00 & 5.909102 \mathrm{E}+00 & 1.100761 \mathrm{E}+01 & 0.000000 \mathrm{E}+00 \\ \text { NORMAL TEST STATISTIC } & 2.391044 \mathrm{E}-01 & -3.030618 \mathrm{E}-01 & 3.831010 \mathrm{E}-01 & -5.617968 \mathrm{E}-01\end{array}$

BRAIN (191-2)

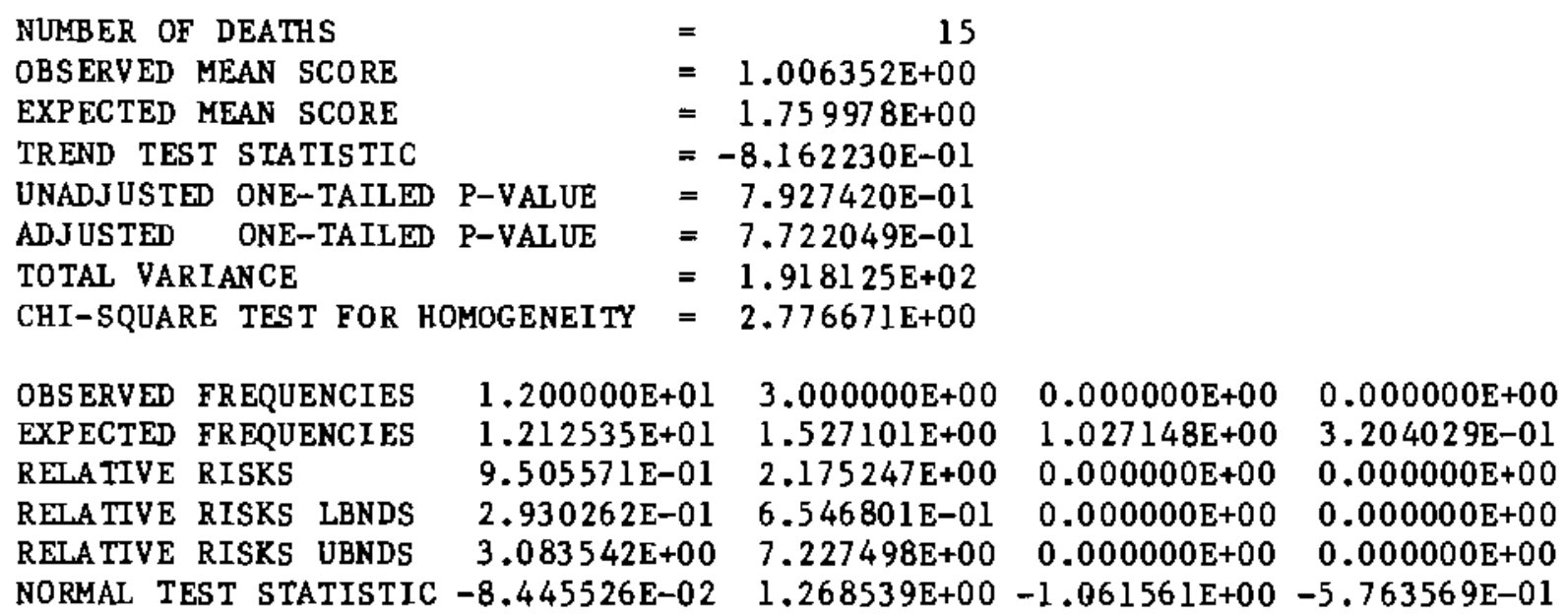


LYMPHOSARCOMA (200)

$\begin{array}{llr}\text { NUMBER OF DEATHS } & = & 13 \\ \text { OBSERVED MEAN SCORE } & =1.503319 \mathrm{E}+00 \\ \text { EXPECTED MEAN SCORE } & =1.693167 \mathrm{E}+00 \\ \text { TREND TEST STATISTIC } & =-2.007466 \mathrm{E}-01 \\ \text { UNADJUSTED ONE-TAILED P-VALUE } & =5.795950 \mathrm{E}-01 \\ \text { ADJUSTED ONE-TAILED P-VALUE } & =5.082139 \mathrm{E}-01 \\ \text { TOTAL VARIANCE } & =1.511486 \mathrm{E}+02 \\ \text { CHI-SQUARE TEST FOR HOMOGENEITY } & =7.103999 \mathrm{E}-01\end{array}$

$1.000000 \mathrm{E}+01 \quad 2.000000 \mathrm{E}+00$ EXPECTED FREQUENCIES $1.058341 \mathrm{E}+01 \quad 1.420938 \mathrm{E}+00$ RELA TIVE RISKS $\quad 7.614824 \mathrm{E}-01 \quad 1.490017 \mathrm{E}+00$ RELATIVE RISKS LBNDS $2.308635 \mathrm{E}-01 \quad 3.391553 \mathrm{E}-01$ RELAATIVE RISKS UBNDS $2.511681 \mathrm{E}+00 \quad 6.546120 \mathrm{E}+00$ NORMAL TEST STATISTIC $-4.475102 \mathrm{E}-01$
$1.000000 \mathrm{E}+00 \quad 0.000000 \mathrm{E}+00$ $6.987175 \mathrm{E}-01 \quad 2.969379 \mathrm{E}-01$ $1.473354 \mathrm{E}+00 \quad 0.000000 \mathrm{E}+00$ $1.972836 \mathrm{E}-01 \quad 0.000000 \mathrm{E}+00$ $1.100331 \mathrm{E}+01 \quad 0.000000 \mathrm{E}+00$ $3.777783 \mathrm{E}-01-5.723923 \mathrm{E}-01$

HODGKIN'S DISEASE (201)

NUMBER OF DEATHS

OBSERVED MEAN SCORE

EXPECTED MEAN SCORE

TREND TEST STATISTIC

UNADJUSTED ONE-TAILED P-VALUE

ADJUSTED ONE-TAILED P-VALUE

TOTAL VARIANCE

CHI-SQUARE TEST FOR HOMOGENEITY
$=$

$=4.896379 \mathrm{E}-01$

$=1.385803 \mathrm{E}+00$

$=-7.751489 \mathrm{E}-01$

$=7.808033 \mathrm{E}-01$

$=7.293989 \mathrm{E}-01$

$=4.811806 \mathrm{E}+01$

$=\quad 1.157359 \mathrm{E}+00$
OBS ERVED FREQUENCIES
$6.000000 \mathrm{E}+00$
$0.000000 \mathrm{E}+00$
$0.000000 \mathrm{E}+00$
$5.412361 \mathrm{E}-01$
$3.051906 \mathrm{E}-01$
$0.000000 \mathrm{E}+00$
RELA TIVE RISKS
$5.082157 \mathrm{E}+00$
$0.000000 \mathrm{E}+00$
$0.000000 \mathrm{E}+00$
$7.141691 \mathrm{E}-02$
RELATIVE RISKS LBNDS
$3.828108 \mathrm{E}-06$
$0.000000 \mathrm{E}+00$
$0.000000 \mathrm{E}+00$
$0.000000 \mathrm{E}+00$
RELATIVE RISKS UBNDS
$3.871445 \mathrm{E}+18$
$0.000000 \mathrm{E}+00$
$0.000000 \mathrm{E}+00$
$0.000000 \mathrm{E}+00$
NORMAL TEST STATISTIC 
OTHER LYMPHATIC NEOPLASMS $(202,208-9)$

$\begin{array}{llr}\text { NUMB ER OF DEATHS } & = & 6 \\ \text { OBSERVED MEAN SCORE } & =4.896379 \mathrm{E}-01 \\ \text { EXPECTED MEAN SCORE } & =1.793769 \mathrm{E}+00 \\ \text { TREND TEST STATISTIC } & = & -8.401386 \mathrm{E}-01 \\ \text { UNADJUSTED ONE-TAILED P-VALUE } & =7.995129 \mathrm{E}-01 \\ \text { ADJUSTED ONE-TAILED P-VALUE } & =7.625324 \mathrm{E}-01 \\ \text { TOTAL VARIANCE } & =8.674473 \mathrm{E}+01 \\ \text { CHI-SQUARE TEST FOR HOMOGENEITY } & =1.456770 \mathrm{E}+00\end{array}$

$\begin{array}{lrrrrr}\text { OBSERVED FREQUENCIES } & 6.000000 \mathrm{E}+00 & 0.000000 \mathrm{E}+00 & 0.000000 \mathrm{E}+00 & 0.000000 \mathrm{E}+00 \\ \text { EXPECTED FREQUENCIES } & 4.888952 \mathrm{E}+00 & 6.171119 \mathrm{E}-01 & 3.251053 \mathrm{E}-01 & 1.688308 \mathrm{E}-01 \\ \text { RELATIVE RISKS } & 4.660073 \mathrm{E}+06 & 0.000000 \mathrm{E}+00 & 0.000000 \mathrm{E}+00 & 0.000000 \mathrm{E}+00 \\ \text { RELATIVE RISKS LBNDS } & 6.849656 \mathrm{E}-05 & 0.000000 \mathrm{E}+00 & 0.000000 \mathrm{E}+00 & 0.000000 \mathrm{E}+00 \\ \text { REILATIVE RISKS UBNDS } & 3.170429 \mathrm{E}+17 & 0.000000 \mathrm{E}+00 & 0.000000 \mathrm{E}+00 & 0.000000 \mathrm{E}+00 \\ \text { NORMAL TEST STATISTIC } & 1.206534 \mathrm{E}+00 & -8.355736 \mathrm{E}-01 & -5.941058 \mathrm{E}-01 & -4.238072 \mathrm{E}-01\end{array}$

MULTIPLE MYELOMA (203)

\begin{tabular}{|c|c|c|c|c|c|}
\hline NUMBER OF DEATHS & & $=$ & 7 & & \\
\hline OBSERVED MEAN SCORE & & $=$ & $5.846665 E+00$ & & \\
\hline EXPECTED MEAN SCORE & & $=$ & $1.262257 \mathrm{E}+00$ & & \\
\hline TREND TEST STATISTIC & & $=$ & $4.519057 \mathrm{E}+00$ & & \\
\hline UNADJUSTED ONE-TAILED & P-VALUE & $=$ & $3.099442 \mathrm{E}-06$ & & \\
\hline ONE-TAILED & P-VALUE & $=$ & $1.103023 \mathrm{E}-03$ & & \\
\hline TOTAL VARIANCE & & $=$ & $5.042746 \mathrm{E}+01$ & & \\
\hline CHI-SQUARE TEST FOR HC & MOGENEITY & $=$ & $2.413103 \mathrm{E}+01$ & & \\
\hline OBSERVED FREQUENCIES & $4.000000 \mathrm{E}+$ & +00 & $0.000000 \mathrm{E}+00$ & $2.000000 \mathrm{E}+00$ & $1.000000 \mathrm{E}+00$ \\
\hline EXPECTED FREQUENCIES & $6.032353 \mathrm{E}+$ & +00 & $6.185393 \mathrm{E}-01$ & $2.738355 \mathrm{E}-01$ & $7.527228 \mathrm{E}-02$ \\
\hline RELATIVE RISKS & $1.667236 \mathrm{E}-$ & -01 & $0.000000 \mathrm{E}+00$ & $1.204375 \mathrm{E}+01$ & $2.371498 E+01$ \\
\hline RELATIVE RISKS LBNDS & $3.540778 \mathrm{E}-$ & -02 & $0.000000 \mathrm{E}+00$ & $2.857560 \mathrm{E}+00$ & $3.875204 \mathrm{E}+00$ \\
\hline RELATIVE RISKS UBNDS & $7.850466 \mathrm{E}-$ & -01 & $0.000000 \mathrm{E}+00$ & $5.076071 \mathrm{E}+01$ & $1.451280 E+02$ \\
\hline NORMAL TEST STATISTIC & $-2.266146 \mathrm{E}+$ & +00 & $-8.298516 \mathrm{E}-01$ & $3.390537 \mathrm{E}+00$ & $3.425636 \mathrm{E}+00$ \\
\hline
\end{tabular}


RESULTS OF ANALYSES BASED ON GROUPED EXPOSURE DATA

OTHER LEUKEMIA $(204,206-7)$

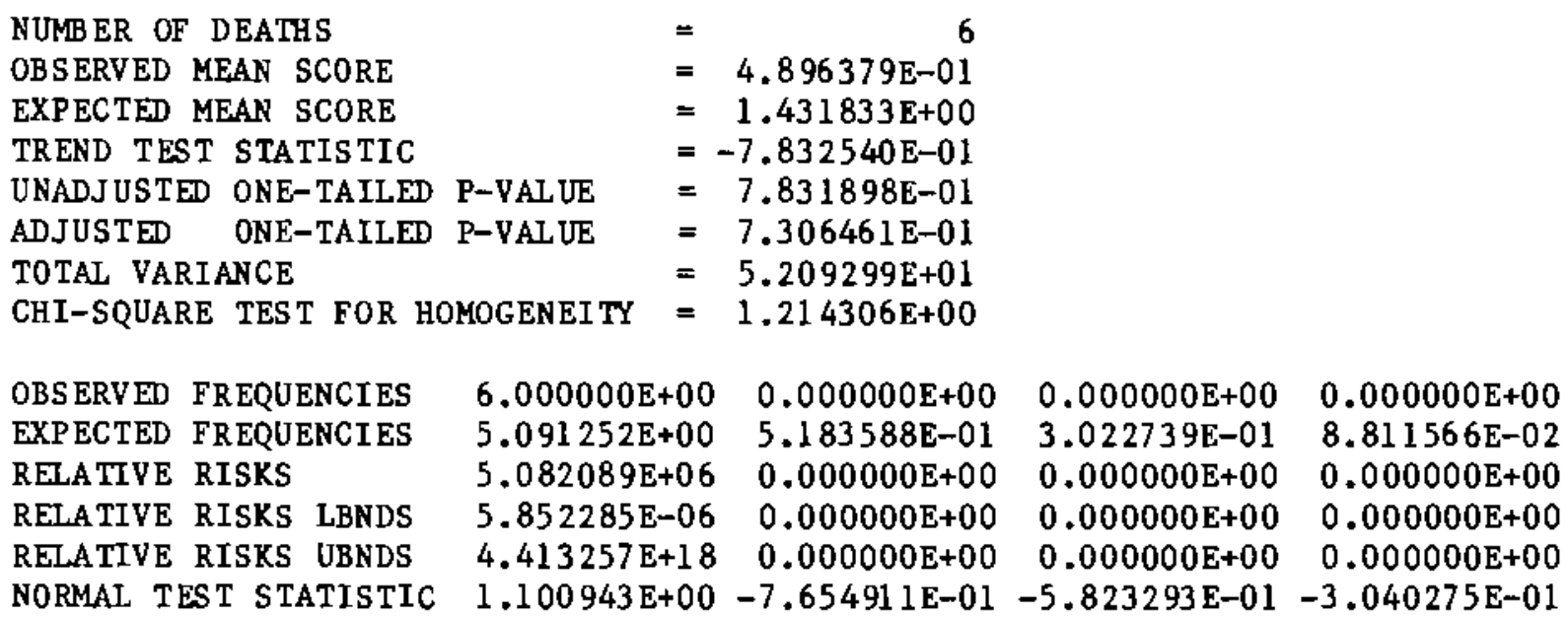

MYLOID LEUKEMIA (205)

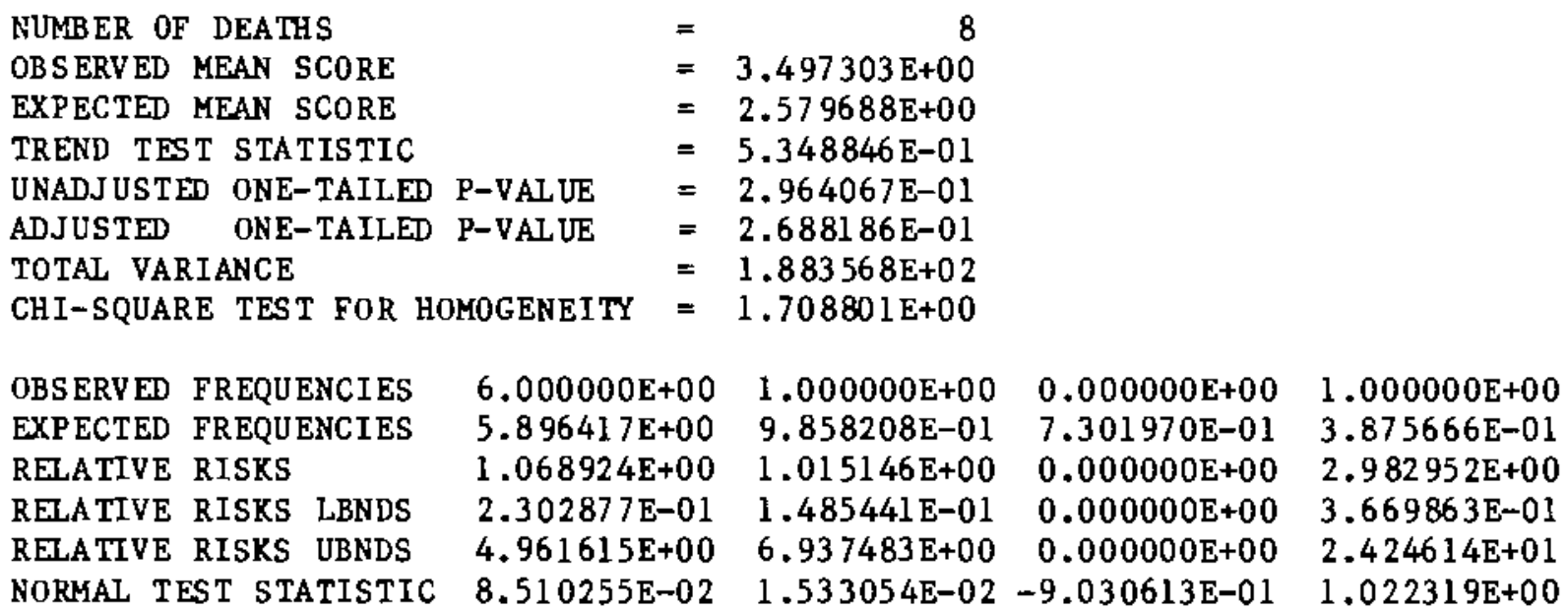


RESULTS OF ANALYSES BASED ON GROUPED EXPOSURE DATA

INFECTIOUS (1-136)

NUMBER OF DEATHS

OBSERVED MEAN SCORE

EXPECTED MEAN SCORE

TREND TEST STATISTIC

UNADJUSTED ONE-TAILED P-VALUE

ADJUSTED ONE-TAILED P-VALUE

TOTAL VARIANCE

CHI-SQUARE TEST FOR HOMOGENEITY
$=6$

$=9.202325 \mathrm{E}-01$

$=2.481569 \mathrm{E}+00$

$=-7.936050 \mathrm{E}-01$

$=7.862158 \mathrm{E}-01$

$=7.510999 \mathrm{E}-01$

$=1.393435 \mathrm{E}+02$

$=9.097429 \mathrm{E}-01$

$\begin{array}{lllllr}\text { OBSERVED FREQUENCIES } & 5.000000 \mathrm{E}+00 & 1.000000 \mathrm{E}+00 & 0.000000 \mathrm{E}+00 & 0.000000 \mathrm{E}+00 \\ \text { EXPECTED FREQUENCIES } & 4.490551 \mathrm{E}+00 & 7.682626 \mathrm{E}-01 & 4.419899 \mathrm{E}-01 & 2.991966 \mathrm{E}-01 \\ \text { RELATIVE RISKS } & 1.688721 \mathrm{E}+00 & 1.358989 \mathrm{E}+00 & 0.000000 \mathrm{E}+00 & 0.000000 \mathrm{E}+00 \\ \text { RELATIVE RISKS LBNDS } & 2.185054 \mathrm{E}-01 & 1.684281 \mathrm{E}-01 & 0.000000 \mathrm{E}+00 & 0.000000 \mathrm{E}+00 \\ \text { RELATIVE RISKS UBNDS } & 1.305129 \mathrm{E}+01 & 1.096522 \mathrm{E}+01 & 0.000000 \mathrm{E}+00 & 0.000000 \mathrm{E}+00 \\ \text { NORMAL TEST STATISTIC } & 5.022131 \mathrm{E}-01 & 2.879388 \mathrm{E}-01 & -7.041661 \mathrm{E}-01 & -5.679103 \mathrm{E}-01\end{array}$

ENDOCRINE (240-79)

$\begin{array}{llr}\text { NUMBER OF DEATHS } & = \\ \text { OBSERVED MEAN SCORE } & =1.984061 \mathrm{E}+00 \\ \text { EXPECTED MEAN SCORE } & =1.725576 \mathrm{E}+00 \\ \text { TREND TEST STATISTIC } & =4.474491 \mathrm{E}-01 \\ \text { UNADJUSTED ONE-TAILED P-VALUE } & =3.272961 \mathrm{E}-01 \\ \text { ADJUSTED ONE-TAILED P-VALUE } & =3.021213 \mathrm{E}-01 \\ \text { TOTAL VARIANCE } & =5.609840 \mathrm{E}+02 \\ \text { CHI-SQUARE TEST FOR HOMOGENEITY } & =1.385228 \mathrm{E}+00\end{array}$

$\begin{array}{lrrrrr}\text { OBS ERVED FREQUENCIES } & 3.300000 \mathrm{E}+01 & 3.000000 \mathrm{E}+00 & 4.000000 \mathrm{E}+00 & 1.000000 \mathrm{E}+00 \\ \text { EXPECTED FREQUENCIES } & 3.399444 \mathrm{E}+01 & 3.627538 \mathrm{E}+00 & 2.320543 \mathrm{E}+00 & 1.057479 \mathrm{E}+00 \\ \text { REILATIVE RISKS } & 8.376199 \mathrm{E}-01 & 8.101261 \mathrm{E}-01 & 1.837582 \mathrm{E}+00 & 9.431806 \mathrm{E}-01 \\ \text { RELATIVE RISKS LBNDS } & 3.738810 \mathrm{E}-01 & 2.488525 \mathrm{E}-01 & 6.540661 \mathrm{E}-01 & 1.278957 \mathrm{E}-01 \\ \text { RELATIVE RISKS UBNDS } & 1.876552 \mathrm{E}+00 & 2.637323 \mathrm{E}+00 & 5.162639 \mathrm{E}+00 & 6.955587 \mathrm{E}+00 \\ \text { NORMAL TEST STATISTIC } & -4.305510 \mathrm{E}-01 & -3.496549 \mathrm{E}-01 & 1.154469 \mathrm{E}+00 & -5.738375 \mathrm{E}-02\end{array}$


BLOOD (280-9)

$\begin{array}{llr}\text { NUMB ER OF DEATHS } & = & 3 \\ \text { OBSERVED MEAN SCORE } & \mathbf{x} & 7.648891 \mathrm{E}+00 \\ \text { EXPECTED MEAN SCORE } & =2.111725 \mathrm{E}+00 \\ \text { TREND TEST STATISTIC } & =2.244198 \mathrm{E}+00 \\ \text { UNADJUSTED ONE-TAILED P-VALUE } & =1.240826 \mathrm{E}-02 \\ \text { ADJUSTED ONE-TAILED P-VALUE } & =3.705363 \mathrm{E}-02 \\ \text { TOTAL VARIANCE } & =5.478923 \mathrm{E}+01 \\ \text { CHI-SQUARE TES T FOR HOMOGENEITY } & =7.894232 \mathrm{E}+00\end{array}$

$\begin{array}{lrrrrr}\text { OBSERVED FREQUENCIES } & 2.000000 \mathrm{E}+00 & 0.000000 \mathrm{E}+00 & 0.000000 \mathrm{E}+00 & 1.000000 \mathrm{E}+00 \\ \text { EXPECTED FREQUENCIES } & 2.367005 \mathrm{E}+00 & 3.113987 \mathrm{E}-01 & 2.112880 \mathrm{E}-01 & 1.103082 \mathrm{E}-01 \\ \text { RELATIVE RISKS } & 5.135173 \mathrm{E}-01 & 0.000000 \mathrm{E}+00 & 0.000000 \mathrm{E}+00 & 1.235247 \mathrm{E}+01 \\ \text { RELATIVE RISKS LBNDS } & 4.542609 \mathrm{E}-02 & 0.000000 \mathrm{E}+00 & 0.000000 \mathrm{E}+00 & 2.085968 \mathrm{E}+00 \\ \text { RELATIVE RISKS UBNDS } & 5.805034 \mathrm{E}+00 & 0.000000 \mathrm{E}+00 & 0.000000 \mathrm{E}+00 & 7.314751 \mathrm{E}+01 \\ \text { NORMAL TEST STATISTIC } & -5.386302 \mathrm{E}-01 & -5.926172 \mathrm{E}-01 & -4.853650 \mathrm{E}-01 & 2.770210 \mathrm{E}+00\end{array}$

MENTAL (290-315)

$\begin{array}{llr}\text { NUMBER OF DEATHS } & = & 12 \\ \text { OBSERVED MEAN SCORE } & =2.947011 \mathrm{E}+00 \\ \text { EXPECTED MEAN SCORE } & =1.999072 \mathrm{E}+00 \\ \text { TREND TEST STATISTIC } & =7.863119 \mathrm{E}-01 \\ \text { UNADJUSTED ONE-TAILED P-VALUE } & =2.159137 \mathrm{E}-01 \\ \text { ADJUSTED ONE-TAILED P-VALUE } & =2.066495 \mathrm{E}-01 \\ \text { TOTAL VARIANCE } & =2.092828 \mathrm{E}+02 \\ \text { CHI-SQUARE TEST FOR HOMOGENEITY } & =1.994913 \mathrm{E}+00\end{array}$

$\begin{array}{llllll}\text { OBSERVED FREQUENCIES } & 1.000000 \mathrm{E}+01 & 0.000000 \mathrm{E}+00 & 1.000000 \mathrm{E}+00 & 1.000000 \mathrm{E}+00 \\ \text { EXPECTED FREQUENCIES } & 9.702197 \mathrm{E}+00 & 1.125439 \mathrm{E}+00 & 7.406365 \mathrm{E}-01 & 4.317271 \mathrm{E}-01 \\ \text { RELA TIVE RISKS } & 1.207856 \mathrm{E}+00 & 0.000000 \mathrm{E}+00 & 1.393468 \mathrm{E}+00 & 2.695889 \mathrm{E}+00 \\ \text { RELATIVE RISKS LBNDS } & 2.439196 \mathrm{E}-01 & 0.000000 \mathrm{E}+00 & 1.799059 \mathrm{E}-01 & 3.087624 \mathrm{E}-01 \\ \text { REIAATIVE RISKS UBNDS } & 5.981134 \mathrm{E}+00 & 0.000000 \mathrm{E}+00 & 1.079317 \mathrm{E}+01 & 2.353855 \mathrm{E}+01 \\ \text { NORMAL TEST STATISTIC } & 2.313715 \mathrm{E}-01 & -1.134626 \mathrm{E}+00 & 3.176759 \mathrm{E}-01 & 8.970312 \mathrm{E}-01\end{array}$


NERVOUS \& SENSORY (320-89)

$\begin{array}{llr}\text { NUMBER OF DEATHS } & = & 17 \\ \text { OBSERVED MEAN SCORE } & =2.847448 \mathrm{E}+00 \\ \text { EXPECTED MEAN SCORE } & =1.925955 \mathrm{E}+00 \\ \text { TREND TEST STATISTIC } & =9.478530 \mathrm{E}-01 \\ \text { UNADJUSTED ONE-TAILED P-VALUE } & =1.716704 \mathrm{E}-01 \\ \text { ADJUSTED ONE-TAILED P-VALUE } & =1.701998 \mathrm{E}-01 \\ \text { TOTAL VARIANCE } & =2.731490 \mathrm{E}+02 \\ \text { CHI-SQUARE TEST FOR HOMOGENEITY } & =1.766550 \mathrm{E}+00\end{array}$

$\begin{array}{lrrrrr}\text { OBSERVED FREQUENCIES } & 1.300000 \mathrm{E}+01 & 1.000000 \mathrm{E}+00 & 2.000000 \mathrm{E}+00 & 1.000000 \mathrm{E}+00 \\ \text { EXPECTED FREQUENCIES } & 1.360439 \mathrm{E}+01 & 1.836966 \mathrm{E}+00 & 1.025074 \mathrm{E}+00 & 5.335699 \mathrm{E}-01 \\ \text { RELATIVE RISKS } & 7.919396 \mathrm{E}-01 & 4.844627 \mathrm{E}-01 & 2.113961 \mathrm{E}+00 & 2.002754 \mathrm{E}+00 \\ \text { RELATIVE RISKS LBNDS } & 2.394663 \mathrm{E}-01 & 5.735486 \mathrm{E}-02 & 4.901460 \mathrm{E}-01 & 2.528638 \mathrm{E}-01 \\ \text { RELATIVE RISKS UBNDS } & 2.619026 \mathrm{E}+00 & 4.092139 \mathrm{E}+00 & 9.117343 \mathrm{E}+00 & 1.586240 \mathrm{E}+01 \\ \text { NORMAL TEST STATISTIC } & -3.822590 \mathrm{E}-01 & -6.656916 \mathrm{E}-01 & 1.003810 \mathrm{E}+00 & 6.577982 \mathrm{E}-01\end{array}$

CIRCULATORY (390-458)

$\begin{array}{llr}\text { NUMB ER OF DEATHS } & = & 1263 \\ \text { OBSERVED MEAN SCORE } & =1.586263 \mathrm{E}+00 \\ \text { EXPECTED MEAN SCORE } & =1.647070 \mathrm{E}+00 \\ \text { TREND TEST STATISTIC } & =-6.099998 \mathrm{E}-01 \\ \text { UNADJUSTED ONE-TAILED P-VALUE } & =7.290133 \mathrm{E}-01 \\ \text { ADJUSTED ONE-TAILED P-VALUE } & =7.250146 \mathrm{E}-01 \\ \text { TOTAL VARIANCE } & =1.585095 \mathrm{E}+04 \\ \text { CHI-SQUARE TEST FOR HOMOGENEITY } & =1.059897 \mathrm{E}+00\end{array}$

$\begin{array}{llrrrr}\text { OBSERVED FREQUENCIES } & 1.063000 \mathrm{E}+03 & 1.070000 \mathrm{E}+02 & 6.600000 \mathrm{E}+01 & 2.700000 \mathrm{E}+01 \\ \text { EXPECTED FREQUENCIES } & 1.054703 \mathrm{E}+03 & 1.140282 \mathrm{E}+02 & 6.367231 \mathrm{E}+01 & 3.059799 \mathrm{E}+01 \\ \text { RELATIVE RISKS } & 1.054730 \mathrm{E}+00 & 9.308625 \mathrm{E}-01 & 1.040135 \mathrm{E}+00 & 8.748019 \mathrm{E}-01 \\ \text { REIAATIVE RISKS LBNDS } & 9.009355 \mathrm{E}-01 & 7.621803 \mathrm{E}-01 & 8.076839 \mathrm{E}-01 & 5.922639 \mathrm{E}-01 \\ \text { RELATIVE RISKS UBNDS } & 1.234778 \mathrm{E}+00 & 1.136877 \mathrm{E}+00 & 1.339484 \mathrm{E}+00 & 1.292124 \mathrm{E}+00 \\ \text { NORMAL TEST STATISTIC } & 6.626517 \mathrm{E}-01 & -7.023589 \mathrm{E}-01 & 3.049262 \mathrm{E}-01 & -6.721411 \mathrm{E}-01\end{array}$


RESP IRATORY (460-519)

NUMBER OF DEATHS OBSERVED MEAN SCORE EXPECTED MEAN SCORE TREND TEST STATISTIC UNADJUSTED ONE-TAILED P-VALUE $=\quad 122$

$=1.731772 \mathrm{E}+00$

$=1.556239 \mathrm{E}+00$

$=5.584219 \mathrm{E}-01$

ADJUSTED ONE-TAILED P-VALUE $=2.751925 \mathrm{E}-01$

TOTAL VARIANCE

$=1.470664 \mathrm{E}+03$

CHI-SQUARE TEST FOR HOMOGENEITY $=2.072628 \mathrm{E}+00$

$\begin{array}{lrrrrr}\text { OBSERVED FREQUENCIES } & 1.010000 \mathrm{E}+02 & 1.300000 \mathrm{E}+01 & 4.000000 \mathrm{E}+00 & 4.000000 \mathrm{E}+00 \\ \text { EXPECTED FREQUENCIES } & 1.038885 \mathrm{E}+02 & 9.791576 \mathrm{E}+00 & 5.484817 \mathrm{E}+00 & 2.835062 \mathrm{E}+00 \\ \text { RELATIVE RISKS } & 8.191175 \mathrm{E}-01 & 1.385334 \mathrm{E}+00 & 7.091138 \mathrm{E}-01 & 1.456851 \mathrm{E}+00 \\ \text { RELATIVE RISKS LBNDS } & 4.928353 \mathrm{E}-01 & 7.689337 \mathrm{E}-01 & 2.551398 \mathrm{E}-01 & 5.179315 \mathrm{E}-01 \\ \text { RELATIVE RISKS UBNDS } & 1.361415 \mathrm{E}+00 & 2.495858 \mathrm{E}+00 & 1.970850 \mathrm{E}+00 & 4.097870 \mathrm{E}+00 \\ \text { NORMAL TEST STATISTIC } & -7.697516 \mathrm{E}-01 & 1.085194 \mathrm{E}+00 & -6.590941 \mathrm{E}-01 & 7.131224 \mathrm{E}-01\end{array}$

DIGESTIVE (520-77)

NUMBER OF DEATHS

$=95$

OBSERVED MEAN SCORE

EXPECTED MEAN SCORE

TREND TEST STATISTIC

UNADJUSTED ONE-TAILED P-VALUE

ADJUSTED ONE-TAILED P-VALUE

TOTAL VARIANCE

$=5.355694 \mathrm{E}-01$

CHI-SQUARE TEST FOR HOMOGENEITY $=1.850110 \mathrm{E}+00$
$=1.328359 \mathrm{E}+03$

$=1.720004 \mathrm{E}+00$

$=1.778967 \mathrm{E}+00$

$=-1.536891 \mathrm{E}-01$

$=5.611203 \mathrm{E}-01$

$\begin{array}{llllll}\text { OBSERVED FREQUENCIES } & 7.800000 \mathrm{E}+01 & 1.100000 \mathrm{E}+01 & 3.000000 \mathrm{E}+00 & 3.000000 \mathrm{E}+00 \\ \text { EXPECTED FREQUENCIES } & 7.776900 \mathrm{E}+01 & 9.021192 \mathrm{E}+00 & 5.728725 \mathrm{E}+00 & 2.481088 \mathrm{E}+00 \\ \text { RELATIVE RISKS } & 1.017590 \mathrm{E}+00 & 1.254897 \mathrm{E}+00 & 4.962852 \mathrm{E}-01 & 1.221172 \mathrm{E}+00 \\ \text { RELATIVE RISKS LBNDS } & 5.953414 \mathrm{E}-01 & 6.646061 \mathrm{E}-01 & 1.569895 \mathrm{E}-01 & 3.847862 \mathrm{E}-01 \\ \text { RELATIVE RISRS UBNDS } & 1.739321 \mathrm{E}+00 & 2.369473 \mathrm{E}+00 & 1.568889 \mathrm{E}+00 & 3.875558 \mathrm{E}+00 \\ \text { NORMAL TEST STATISTIC } & 6.375664 \mathrm{E}-02 & 7.001492 \mathrm{E}-01 & -1.193065 \mathrm{E}+00 & 3.391091 \mathrm{E}-01\end{array}$


RESIDUAL (210-39,580-799)

NUMBER OF DEATHS OBSERVED MEAN SCORE EXPECTED MEAN SCORE TREND TEST STATISTIC UNADJUSTED ONE-TAILED P-VALUE ADJUSTED ONE-TAILED P-VALUE TOTAL VARIANCE CHI-SQUARE TEST FOR HOMOGENEITY
$=$

$=1.162644 \mathrm{E}+00$

$=1.525464 \mathrm{E}+00$

$=-7.130120 \mathrm{E}-01$

$=7.620133 \mathrm{E}-01$

$=7.421056 \mathrm{E}-01$

$=4.787684 \mathrm{E}+02$

$=1.672708 \mathrm{E}+00$
OBSERVED FREQUENCIES

EXPECTED FREQUENCIES

REIAATVE RISKS

RELATIVE RISKS LBNDS

RELATIVE RISKS UBNDS

NORMAL TEST STATISTIC $-3.125150 \mathrm{E}-01$
$3.600000 \mathrm{E}+01$

$3.668418 \mathrm{E}+01$

$8.640640 \mathrm{E}-01$

$3.456057 \mathrm{E}-01$

$2.160285 \mathrm{E}+00$

$5.000000 \mathrm{E}+00$

$3.450305 \mathrm{E}+00$

$1.567987 \mathrm{E}+00$

$5.781956 \mathrm{E}-01$

$4.252163 \mathrm{E}+00$

$8.836826 \mathrm{E}-01$
$2.000000 \mathrm{E}+00$

$1.924580 \mathrm{E}+00$

$1.042591 \mathrm{E}+00$

$2.476843 \mathrm{E}-01$

$4.388638 \mathrm{E}+00$

$5.687739 \mathrm{E}-0$
$0.000000 \mathrm{E}+00$

$9.409350 \mathrm{E}-01$

$0.000000 \mathrm{E}+00$

$0.000000 \mathrm{E}+00$

$0.000000 \mathrm{E}+00$

EXTERNAL (800-999)

$\begin{array}{llr}\text { NUMBER OF DEATHS } & = & 165 \\ \text { OBSERVED MEAN SCORE } & =1.291625 \mathrm{E}+00 \\ \text { EXPECTED MEAN SCORE } & =1.563660 \mathrm{E}+00 \\ \text { TREND TEST STATISTIC } & =-1.071584 \mathrm{E}+00 \\ \text { UNADJUSTED ONE-TAILED P-VALUE } & =8.579873 \mathrm{E}-01 \\ \text { ADJUSTED ONE-TAILED P-VALUE } & =8.599494 \mathrm{E}-01 \\ \text { TOTAL VARIANCE } & =1.754546 \mathrm{E}+03 \\ \text { CHI-SQUARE TEST FOR HOMOGENEITY } & =1.595055 \mathrm{E}+00\end{array}$

$\begin{array}{lrrrrr}\text { OBSERVED FREQUENCIES } & 1.400000 \mathrm{E}+02 & 1.500000 \mathrm{E}+01 & 9.000000 \mathrm{E}+00 & 1.000000 \mathrm{E}+00 \\ \text { EXPECTED FREQUENCIES } & 1.375899 \mathrm{E}+02 & 1.556326 \mathrm{E}+01 & 8.720366 \mathrm{E}+00 & 3.126421 \mathrm{E}+00 \\ \text { RELATIVE RISKS } & 1.132640 \mathrm{E}+00 & 9.583126 \mathrm{E}-01 & 1.035303 \mathrm{E}+00 & 3.012903 \mathrm{E}-01 \\ \text { RELATIVE RISKS LBNDS } & 7.142925 \mathrm{E}-01 & 5.541807 \mathrm{E}-01 & 5.215160 \mathrm{E}-01 & 4.517477 \mathrm{E}-02 \\ \text { RELATIVE RISKS UBNDS } & 1.796006 \mathrm{E}+00 & 1.657154 \mathrm{E}+00 & 2.055264 \mathrm{E}+00 & 2.009437 \mathrm{E}+00 \\ \text { NORMAL TEST STATISTIC } & 5.295296 \mathrm{E}-01 & -1.523861 \mathrm{E}-01 & 9.916934 \mathrm{E}-02 & -1.239173 \mathrm{E}+00\end{array}$


MOX TNISHED AT $12: 21: 46$ ON $4-$ NON-83

ELADSED TUE IS 1241.83 


\begin{tabular}{|c|c|c|}
\hline Cause & $\begin{array}{l}\text { order }^{\star} \\
\text { in } \\
\text { Summa ry }\end{array}$ & $\begin{array}{c}\text { Eighth Revision } \\
\text { ICD } \\
\operatorname{Code}(s)\end{array}$ \\
\hline A11 Causes & 1 & $0-999$ \\
\hline None (No Death Certificate) & 2 & 0 \\
\hline All Non-Cancers & 3 & $<140,>209$ \\
\hline All Malignant Neoplasms & 4 & $140-209$ \\
\hline Buccal & 5 & $140-149$ \\
\hline 0ther Digestive & 6 & $150,152,154-6,158-9$ \\
\hline Stomach & 7 & 151 \\
\hline Large Intestine & 8 & 153 \\
\hline Pancreas & 9 & 157 \\
\hline All Other Cancers & 10 & $\begin{array}{l}160-1,163,170-3, \\
186-7,190,193-9\end{array}$ \\
\hline Lung & 11 & 162 \\
\hline Breast & 12 & 174 \\
\hline Cervix & 13 & 180 \\
\hline Uterus & 14 & $181-2$ \\
\hline Other Female & 15 & $183-4$ \\
\hline Prostate & 16 & 185 \\
\hline Bladder and Urinary & 17 & $188-9$ \\
\hline Brain & 18 & $191-2$ \\
\hline Lymphos a rcama & 19 & 200 \\
\hline Hodgkin's & 20 & 201 \\
\hline Other Lymphatic Neoplasms & 21 & $202,208-9$ \\
\hline
\end{tabular}

*If there are not any deaths occuring from a particular cause, the cause is oritted frow the summaries. 
Cause

Cause

Multiple Myeloma

Other Leukemia

Myeloid Leukemia

Infectious

Endocrine

Blood

Mental

Nervous and Sense

Circulatory

Respiratory

Digestive

Residual

External

\begin{tabular}{c} 
order \\
in \\
Summary \\
\hline
\end{tabular}

22

23

24

25

26

27

28

29

30

31

32

33

34
Eighth Revision ICD Code( $\mathrm{B}$ )

203

$204,206-7$

205

$1-136$

$240-79$

$280-9$

$290-315$

$320-89$

$390-458$

$460-519$

$520-577$

$210-39,580-799$

800-999

* If there are not any deaths occuring from a particular cause, the cause is omitted from the summaries. 


\section{DISTRIBUTION}

No. of

Copies

OFFSITE

DOE Office of Health and Environmental Research

Washington, DC 20545

27 DOE Technical Information Center

Dr. Norman Breslow

Department of Biostatistics SC-32

University of Washington

Seattle, WA 98195

Dr. Art G. Johnson

Oregon State University

Radiation Center

35 th and Jefferson

Corvallis, OR 97331

Dr. Robert Miller

Clinical Epidemiology Branch

National Cancer Institute

National Institutes of Health

Bethesda, MD 20014

Dr. G. S. Omenn

School of Public Health and Community Medicine

University of Washington

Seattle, WA 98195

Dr. Roy E. Shore

Department of Environmental Medicine

New York University Medical Ceriter

341 E. 25th St.

New York, NY 10010-2598

lir. Kent B. Stewart

Exxon Nuclear Company, Inc.

2101 Horn Rapids Road

Richland, WA 99352
No. of

Copies

ONSITE

DOE Richiand Operations Office

H. E. Ransom

Hanford Environmental

Health Foundation

G. R. Petersen

35 Pacific Northwest Laboratory

J. A. Buchanan (25)

E. S. Gilbert

S. Marks

H. D. Tolley

Publishing Coordination (2)

Technical Information (5) 


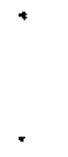

.

.

.

,

.

.

. 